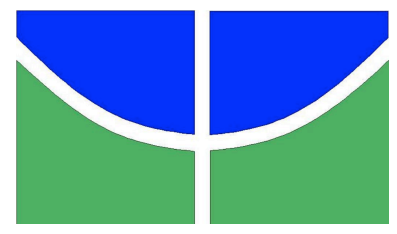

UNIVERSIDADE DE BRASÍLIA

FACULDADE DE COMUNICAÇÃO

PROGRAMA DE PÓS-GRADUAÇÃO

Na estrada com os primeiros road movies de Wim Wenders: viagem, identidade e incomunicação

Rose May Carneiro

TESE DE DOUTORADO

Brasília/DF

Novembro / 2015 


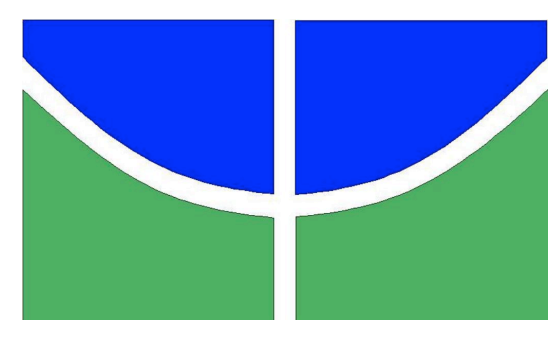

UNIVERSIDADE DE BRASÍLIA FACULDADE DE COMUNICAÇÃO PROGRAMA DE PÓS-GRADUAÇÃO

\title{
Na estrada com os primeiros road movies de Wim Wenders: viagem, identidade e incomunicação
}

\author{
Rose May Carneiro \\ ORIENTADORA: Prof. Dra. Susana M. Dobal Jordan
}

Tese de Doutorado

Brasília/DF

Novembro / 2015 

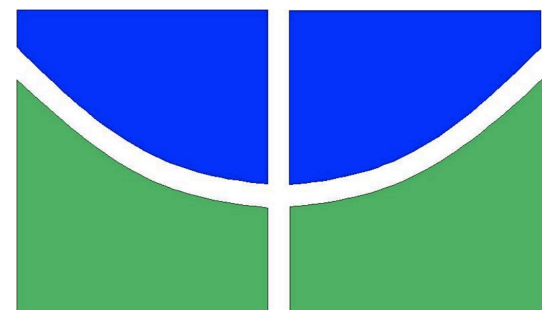

UNIVERSIDADE DE BRASÍLIA

FACULDADE DE COMUNICAÇÃO

PROGRAMA DE PÓS-GRADUAÇÃO

\title{
Na estrada com os primeiros road movies de Wim Wenders: viagem, identidade e incomunicação
}

\author{
Rose May Carneiro
}

TESE DE DOUTORADO SUBMETIDA AO PROGRAMA DE PÓS-GRADUAÇÃO EM COMUNICAÇÃO SOCIAL, COMO PARTE DOS REQUISITOS NECESSÁRIOS À OBTENÇÃO DO GRAU DE DOUTOR EM COMUNICAÇÃO SOCIAL.

APROVADA POR:

SUSANA DOBAL- Orientadora, PROF. DRA., FAC/UNB.

TANIA MONTORO - Membro da Banca, PROF. DRA., FAC/UNB.

ANDRÉ LUIS GOMES - Membro da Banca, PROF. DR., LETRAS/UNB.

FLORENCE DRAVET - Membro da Banca, PROF. DRA., COMUNICAÇÃO/UCB.

KARINA DIAS - Membro da Banca, PROF. DRA., TURISMO/UNB.

GUSTAVO DE CASTRO - Suplente, PROF. DR., FAC;UNB

BRASÍLIA/DF, 30 de novembro de 2015 


\section{FICHA CATALOGRÁFICA}

CARNEIRO, Rose May

$\mathrm{Na}$ Estrada com os primeiros road movies de Wim Wenders: viagem, identidade e incomunicação. / orientação de Susana Dobal. - Brasília, 2015.

(143 páginas) p. : il.

Tese de Doutorado (D) - Universidade de Brasília/Faculdade de Comunicação Social, 2015.

1. Cinema. 2. Road Movies. 3. Wim Wenders. 4. Incomunicabilidade. I. Carneiro, R. II. Título.

CDD ou CDU FAC / UNB

\section{REFERÊNCIA BIBLIOGRÁFICA}

CARNEIRO, R. M. Na Estrada com os primeiros road movies de Wim Wenders: viagem, identidade e incomunicação. Brasília: Faculdade de Comunicação, Universidade de Brasília, 2015, (143 p.)Tese de Doutorado.

\section{CESSÃO DE DIREITOS}

Rose May Carneiro:

Na Estrada com os primeiros road movies de Wim Wenders: viagem, identidade e incomunicação GRAU: DOUTORADO ANO: 2015

É concedida à Universidade de Brasília a permissão para reproduzir cópias desta tese de doutorado para única e exclusivamente propósitos acadêmicos e científicos. A autora reserva para si os outros direitos autorais, de publicação. Nenhuma parte desta tese de doutorado pode ser reproduzida sem a autorização por escrito do autor. Citações são estimuladas, desde que citada à fonte.

Nome: Rose May Carneiro

CPF: 12723603857

Endereço: SHIS QI 29 CJ 9 casa 23

Tel: 61 - 8154-0636 Email: rosemaybsb@gmail.com 


\section{Agradecimentos}

Agradeço a zeus, a buda, a krishna e aos orixás.

A tudo e todos que me trouxeram até aqui. À Capes pela bolsa que muito me ajudou nessa pesquisa. Aos amigos, de sempre, pelo apoio e paciência inestimável. À família (Tânia, Antônio, Daisy, Krikor, Drika, Ju, Lucas) que nunca me deixou desistir. Às minhas duas mães (Lourdes e Alice), lá no andar de cima, pela fé inabalável. Ao programa de Pós-Graduação da $\mathrm{FAC} / \mathrm{UnB}$, por todo o aprendizado. Aos professores da Pós-Graduação da FAC/UnB, pela amizade e o estímulo constante. À Zoe, Julie, Belinha, Vita e Dudu (in memorian) pelo amor animal.

À Marcela Ribeiro (namorada linda) pela confiança e o amor incondicional.

À Brasília, pelo acolhimento de sempre.

Aos meus alunos, pela compreensão.

Aos miojos, pizzas, chocolates e cocas-colas, pela energia.

Ao Wim Wenders, por me deixar descobrir.

Ao Cinema, pela eterna paixão.

Ao Cosmos, por sobreviver.

E, finalmente, a minha orientadora Susana M. Dobal Jordan, pelo refinamento, sabedoria e paciência.

Muito obrigada! 


\section{Sumário}

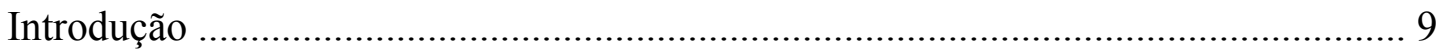

1. Os principais conceitos que vão nos guiar pelo caminho ….................................. 33

1.1 Wim Wenders e a poética de um cinema ...................................................... 38

2. Da literatura de viagem aos road movies ............................................................ 50

2.1 Alice nas Cidades - A representação de espaços em trânsito ................................ 56

3 . Incomunicação, solidão e silêncio - movimento de interiorização .......................... 74

3.1. Movimento em falso - um cinema contemplativo ............................................. 83

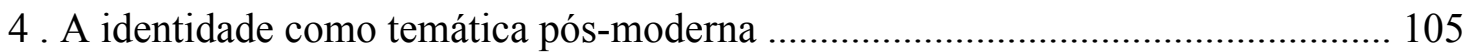

4.1. No decurso do tempo - Em busca da identidade perdida .................................. 109

5. Conclusão - Uma estrada sem fim ................................................................... 128

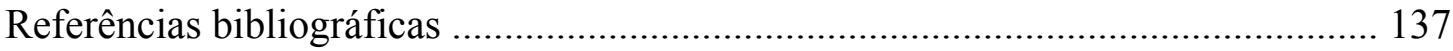

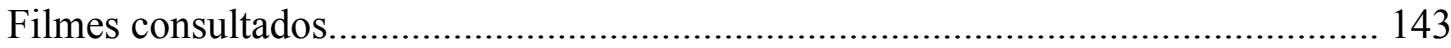


O objetivo desta tese é analisar os filmes que iniciam a trilogia on the road do cineasta alemão Wim Wenders: Alice nas Cidades (Alice in den Städten / 1974), Movimento em Falso (Falsche Bewegung / 1975 ) e No Decurso do Tempo (Im Lauf der Zeit/1976). Por meio da viagem e do ato de viajar, os filmes de Wim Wenders percorrem estradas repletas de temas existenciais que nos ajudam a refletir sobre a condição humana, na contemporaneidade. Nas suas paisagens áridas e impactantes, seus personagens ligamse a questões como a busca da identidade, a incomunicabilidade do homem no mundo contemporâneo, a poesia, a solidão, os silêncios, os grandes espaços vazios, além da reflexão sobre a transitoriedade da imagem que perpassa a pintura, a fotografia, os gêneros, como o da paisagem, até chegar na transitoriedade do cinema.

Palavras-chave: Wim Wenders. Fotografia. Cinema. Filmes on the road. Viagem. Identidade. Incomunicação. 
The objective of this thesis is to analyze the films that compose the trilogy on the road by the German filmmaker Wim Wenders: Alice in the Cities (Alice in den Städten / 1974), Wrong Move (Falsche Bewegung / 1975) and Kings of the Road (Im Lauf der Zeit / 1976). Through the journey itself and the act of traveling, Wim Wenders films run through roads charged with existential themes that help us reflect on the human condition in contemporary times, considered also from a cultural perspective. In the arid and striking landscapes of the films, the characters are bound to connect to issues such as the search for identity, the lack of communication in the contemporary world, poetry, solitude, silence, geographical emptiness as well as the reflection on the image of transience running through painting, photography, genres such as landscape, until it reaches the transience of cinema itself.

KEY-WORDS: Wim Wenders. Photography. Cinema. Movies on the road. Travelling. Identity. Lack of communication. 
O mundo se uniformiza, os meios de telecomunicação se aperfeiçoam, as relações humanas se tornam progressivamente impossíveis.

Michel Houellebecq (2014, p.18)

\section{Introdução}

Numa manhã ensolarada, em plenos anos 70, um técnico de projeção de filmes, ao fazer a barba em seu caminhão-casa, vê um fusca a mil por hora se jogar nas águas geladas do rio Elba (que na época dividia a Alemanha Ocidental da Oriental). O suicida frustrado - tanto com o rompimento com sua ex-esposa quanto com aquele que deveria ser seu ato derradeiro - retira sua mala de dentro do carro lentamente, sai dele, nada até as margens, escapa, pela janela, com um terno ensopado e a tal mala nas mãos, encontra, em seguida, o técnico blasé. Eles riem.

Naquele momento, começa uma convivência entre ambos. Os dois saem pelas estradas, incrustadas num mundo precário, sem rumo exato. A estrada acaba sendo uma metáfora óbvia dos rumos da vida. Ao longo de todo o percurso, eles trocam diálogos escassos e superficiais. Corta.

A cena descrita acima é um pequeno fragmento do filme No Decurso do Tempo (1976) dirigido por Wim Wenders. Esse filme faz parte do início da sua carreira e, ao mesmo tempo, encerra a sua trilogia on the road que o tornou conhecido mundialmente. O primeiro filme que inicia a trilogia é o Alice Nas Cidades (Alice in den Städten / 1974) e, no ano seguinte, lançou o Movimento Em Falso (Falsche Bewegung, 1975). Sabemos que as imagens, assim como as palavras, têm múltiplos significados e anseiam por dizer coisas. Para os cineastas, imagens são instrumentos. Por meio delas, exprimem a sua arte. Para compreender a experiência do cinema e os reflexos dessa linguagem em nosso cotidiano, precisamos entendê-lo como uma linguagem estética, poética ou musical, com uma sintaxe e um estilo próprio; uma forma de expressão tão ampla quanto as outras linguagens (literatura, teatro etc), bastante elaborada e específica. Conforme enfatizou Betton (1987, p.1), fazer um filme é organizar uma série de elementos espetaculares a fim de proporcionar uma visão estética, objetiva, subjetiva ou poética do mundo. 
Na busca de uma possível correlação entre imagens, viagens e identidade, será pesquisado nesta tese questões que permeiam a incomunicabilidade ou incomunicação, e tudo aquilo que ela, de maneira silenciosa, representa e reverbera em seus textos culturais, nas relações interpessoais e nos meios de comunicação de massa, por meio da análise de algumas cenas onde essas inquietações aparecem, destacadas nos três filmes on the road do cineasta alemão Wim Wenders: Alice nas Cidades (Alice in den Städten / 1974), Movimento em Falso (Falsche Bewegung / 1975 ) e No Decurso do Tempo (Im Lauf der Zeit/1976)

Para compreendermos melhor a incomunicabilidade, buscamos em Baitello (2005, p.9) o comentário que quanto mais se aperfeiçoam os recursos, as técnicas e as possibilidades que o homem tem de se comunicar com o mundo, com os outros homens e consigo mesmo, aumentam também, em idêntica proporção, as suas incapacidades, suas lacunas, seu boicote, seus entraves ao mesmo processo, ampliando um território tão antigo quanto esquecido, o território da incomunicação humana. A comunicação e a incomunicação são irmãs gêmeas que vivem juntas e, muitas vezes, andam de mãos dadas. Embora não percebamos, onde uma está a outra está lá também. Enquanto a comunicação se orgulha dos bons serviços e das suas qualidades, a incomunicação, por sua vez, está ali causando estragos, desfazendo e desmontando, distorcendo e deformando, semeando discórdia e gerando falsas expectativas, invertendo sinais e valores, azedando as relações e produzindo estranhamentos incômodos.

Os filmes em questão evidenciam algumas idiossincrasias do pensamento de Wenders que ecoam essas manifestações: o mundo como dominador do homem, não conquistado por ele; a forma de ver como definidora da forma de viver; a miopia espiritual do homem moderno; as relações deterioradas, o cinema como educador do olhar, e, por fim, alguns deslocamentos entre a fotografia e o próprio cinema frente às novas tecnologias. O gênero road movie tem a estrada como o seu principal espaço de deslocamento. O filme é feito ao longo do seu percurso em uma ordem quase que cronológica. É por meio dela que as personagens transitam em busca de possíveis respostas para as suas indagações e resgates de identidades. 
Em relação à fotografia, é importante frisarmos a relevância dela nos primeiros filmes de Wim Wenders, e até hoje, conforme ele ressalta em entrevista:

\begin{abstract}
${ }^{1} \mathrm{O}$ ato de fotografar me mostrou algo novo. De repente, passei a olhar as coisas, especialmente os lugares, diferentemente e com uma grande precisão, de alguma forma. Percebi que você pode usar a câmera como um dispositivo de gravação para capturar mais do que uma simples imagem - alguma coisa como uma história que pode ser contada por um lugar. (Tradução da autora. (WECKESSER, 2012. p. 14).
\end{abstract}

A paisagem fotografada nos seus filmes é carregada de vestígios. Algumas questões essenciais se fundem com essas imagens: o que esses personagens deixaram para trás? O que eles destruíram? Qual é a expectativa deles nesse lugar? E o que esse lugar, em particular, nos diz sobre a nossa cultura? Esses filmes são todos marcados por uma extrema autorreflexão, que até hoje podemos dizer que ressaltam uma certa característica maior do cinema contemporâneo, como veremos adiante.

A fotografia e as paisagens nos filmes de Wenders (1987, p. 36) assumem um papel fundamental, conforme ele mesmo comenta:

\begin{abstract}
$\mathrm{O}$ ato de filmar é um ato heróico (não sempre, nem sequer frequentemente, mas por vezes). A progressiva distribuição da percepção exterior e do mundo, é, por um instante suspensa. A câmera é uma arma contra a miséria das coisas, nomeadamente contra o seu desaparecimento. Por que filmar? Não saberá de outra pergunta menos idiota?
\end{abstract}

Os cenários de estrada poderiam evocar o hiperrealismo. Há o contraste entre a paisagem inóspita do Oeste e as cidades modernas, com prédios futuristas e envidraçados; entre as auto estradas e os pequenos vilarejos; entre painéis publicitários e personagens desolados no deserto. O diretor alemão, por sua vez, foi influenciado pela pintura do americano Edward Hopper - com seus personagens melancólicos perdidos em bares e quartos de hotéis -e, especialmente, pelo legado de um dos fotógrafos mais importantes e influentes dos Estados Unidos, Walker Evans.

\footnotetext{
1 "The act of taking photographs showed me something new. I was suddenly able to look at things, especially places, completely differently and with greater precision somehow. I noticed that you could use the camera as a recording device to capture more than just an image - something like a story that was told by each place." (WECKESSER, 2012. p. 14)
} 
Esses filmes foram denominados como "novo cinema alemão", 2 introduziram o pós-modernismo no cinema, com uma certa colagem de gêneros e fontes. Essa prática ocorreu em paralelo com a intertextualidade na literatura, além de uma forte influência da fotografia, das artes visuais e da arquitetura. Com um apurado senso de composição, Wenders é um exímio fotógrafo que sempre busca e privilegia a exploração das paisagens desertas da América, com as lentes da sua inseparável câmera Leica, sempre quis eternizar os lugares mais estranhos, calmos e silenciosos. Eis o que o cineasta diz para explicar a sua visão da fotografia:

\footnotetext{
3،"Eu me vejo como um intérprete, como um tradutor, um guardião das histórias que os lugares me contam. Eu penso ter os olhos bem abertos para a América e as suas paisagens que, em geral, se mostram de maneira extremamente atrativas para mim, tanto como fotógrafo quanto cineasta." Trecho extraído do site http://ohomemquesabiademasiado.blogspot.com.br/2015/09/wim-wendersfotografo.html, conforme tradução da autora.
}

Ao longo de sua carreira, já participou de diversas exposições de fotografia mundo afora, inclusive, lançou livros de fotografia que enfatizam quanto mais ermos e vazios for esses lugares, melhor. Para ilustrar melhor o que afirmamos, selecionamos, abaixo, algumas das fotografias de Wim Wenders que denotam o seu modo de ver:

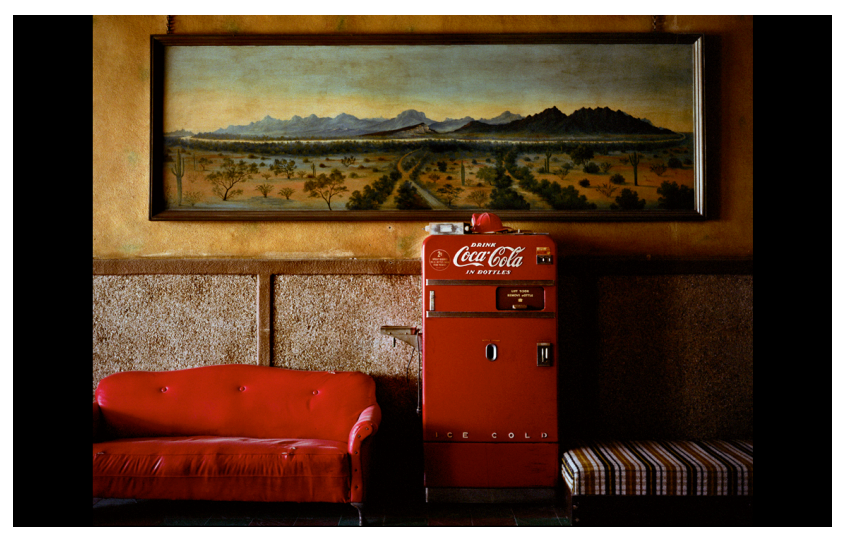

Figura 1: Lounge Painting \#1, Gila Bend, Arizona, 1983

\footnotetext{
2 No próximo capítulo, exploraremos melhor o conceito desse cinema. Ver página 42.

3 "I see myself as an interpreter, as a translator, a guardian of stories that places tell me. I think I had wide-open eyes for America, and 'the American landscape' in a general sense seemed extremely attractive to me, both as a photographer and filmmaker."
} 


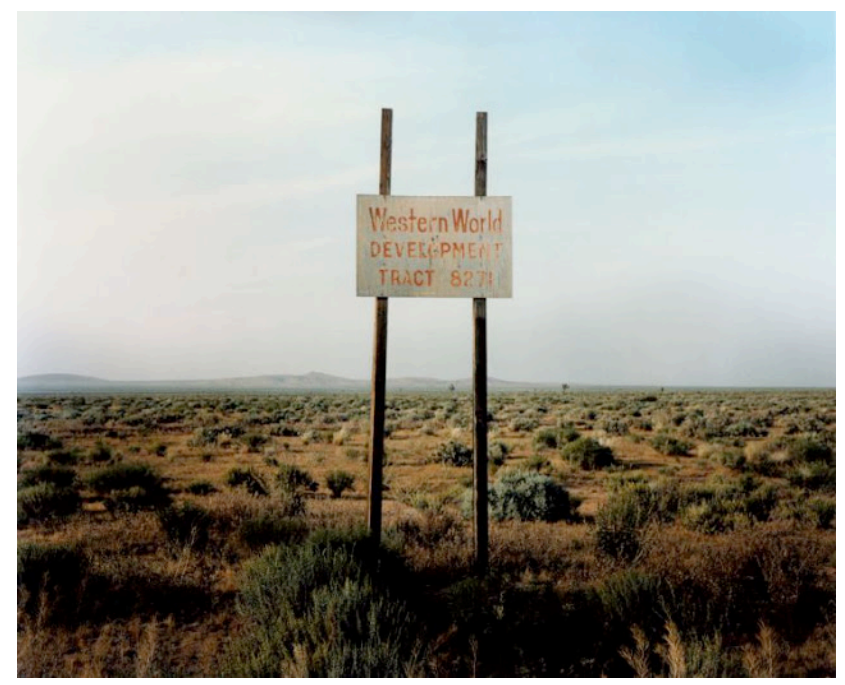

Figura 2: Western-world-development-near-four-corners-california,1986

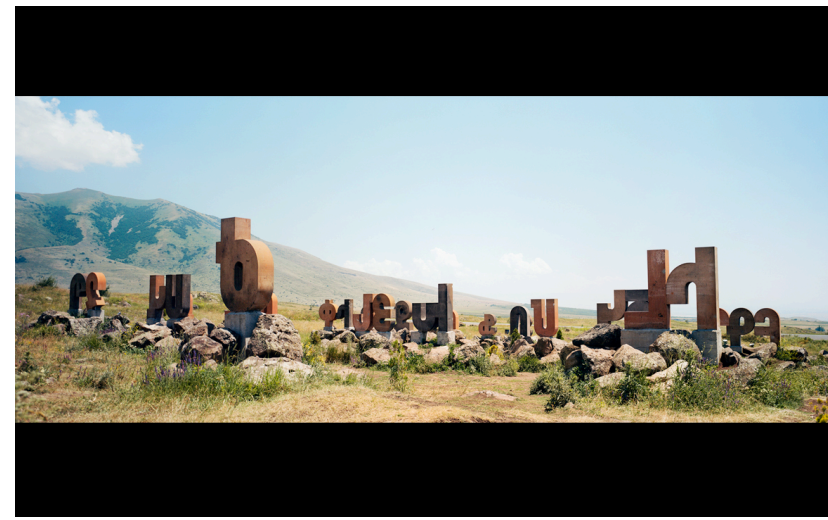

Figura 3: Armenian Alfhabet, 2008

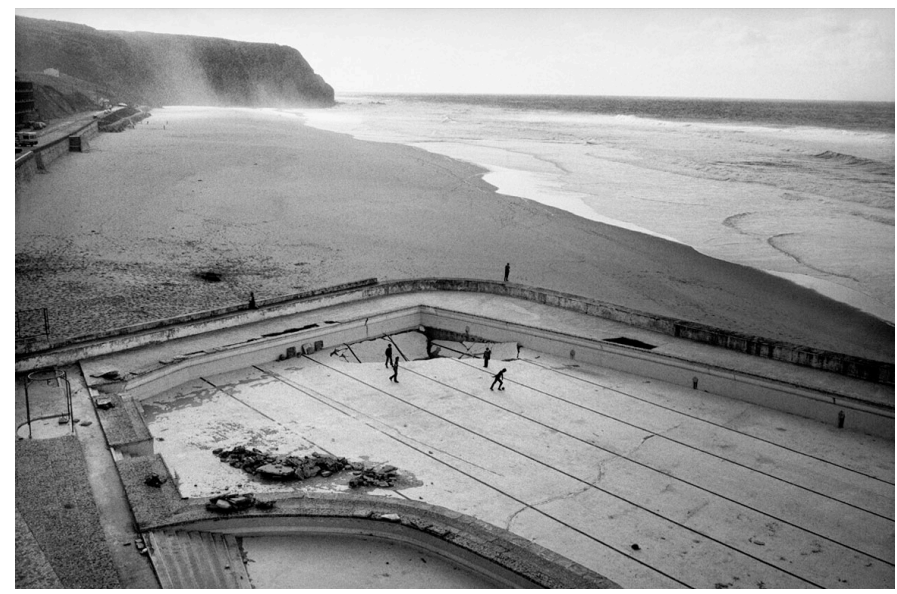

Figura 4: À luz do dia até os sons brilham, 2015 - (título original da última exposição de Wim Wenders feita em Lisboa)

$\mathrm{Na}$ verdade, na maior parte das vezes, os lugares também estão entre os protagonistas principais de seus filmes, muitos dos quais começam com o desejo de 
explorar uma determinada cidade, uma paisagem, um deserto, uma cultura local. Essa é, de fato, a sua visão: ${ }^{4}$

\begin{abstract}
Quando retornei a Berlim, depois de sete anos na América, tive uma vontade enorme de fazer um filme sobre a cidade. Finalmente! Através de Berlim eu tentaria descobrir, redescobrir meu país natal. Mas não conseguia encontrar uma história que desse conta de compreender a cidade, ou que pudesse, ao menos, narrar a sua história. Não conseguia encontrar personagens que me permitissem realmente mostrar a cidade e sua história em toda sua complexidade, verticalmente, através dos tempos. Pensava em bombeiros, médicos, carteiros, mas todas essas idéias pareciam inúteis, não me ofereciam o que eu precisava. Então, perambulando pelas ruas em busca de uma história ou de possíveis personagens, a cidade os sugeriu para mim. Enquanto vagava, meu olhar cruzou com figuras de anjos flutuando em toda a parte. Como monumentos, decorações arquitetônicas, nome de ruas. Estavam presentes em toda parte. Então aceitei aquela dica. Berlim de fato me sugeriu os protagonistas: anjos da guarda. E filmei Asas do desejo. Sem roteiro, apenas com um conhecimento íntimo dos lugares onde queria rodá-lo. "A cidade" realmente evocou o filme.
\end{abstract}

Os filmes de Wim Wenders - repletos de temas existenciais - nas suas paisagens áridas e impactantes, ligam-se às questões como a busca da identidade, a incomunicabilidade do homem no mundo contemporâneo, a solidão, os silêncios, os grandes espaços vazios, além da reflexão sobre a transitoriedade da imagem e o próprio cinema. Seus heróis e sua obra estão em constante movimento. Por outro lado, não são filmes discursivos, mas repletos de silêncios e não ditos. Há momentos de grande lirismo e poesia, além da emergência de um humanismo não realizado. No primeiro filme, Alice nas Cidades (1974), o personagem Philip Winter, inicialmente, não se sente responsável pela menina Alice, abandonada pela mãe. Muito pelo contrário, o seu desejo era continuar a viagem sem se sentir incomodado por uma criança com quem ele não tem a menor idéia de como lidar. Já em seu segundo filme, Movimento em Falso (1975), o personagem Wilhelm se sente obrigado a sair do seu quarto para aprender a se relacionar com outras pessoas e, quem sabe, extrair argumentos para o seu futuro livro. E, finalmente, em seu terceiro filme - No Decurso do Tempo (1976) - o personagem Bruno Winter resolve abdicar, por um tempo, da sua solidão voluntária para criar um vínculo de amizade com o personagem Robert de quem, por ser tão frágil, percebe que pode se desfazer a qualquer momento. No fundo, todos os personagens buscam a liberdade, mas o percurso é longo, repleto de imprevistos e, muitas vezes, inatingível.

\footnotetext{
4 (WENDERS, 2010. p. 22).
} 
A viagem e os dramas existenciais dos personagens, ao longo do trajeto, são elementos constantes nos filmes de Wenders. O viajante é quase sempre um estrangeiro, muitas vezes, dele mesmo, em busca de algum lugar, anseios ou sensações inexploradas. No entanto, nem sempre é assim. Para Wenders, ${ }^{5}$ as pessoas viajam para países estrangeiros, experimentam a comida, bebem a cerveja, visitam as atrações, dirigem por roteiros previamente traçados, vão aos lugares que têm de ser vistos, tiram fotos onde devem tirá-las, para depois ficar olhando para elas quando chegarem em casa, para acreditarem que de fato estiveram lá. Essa é a diferença entre um turista e um viajante. Enquanto o viajante chega, vê, escuta e respeita, o turista continua se sentindo como se ainda estivesse em casa. Nessa dualidade, situamos a deambulação dos personagens de Wenders. Inicialmente, Philip Winter (Alice Nas Cidades) só pensa em fotografar pessoas e lugares porque, assim como a escrita que não flui, também não há muita interação com elas. A interação forçada acontece depois de conhecer Alice e ser obrigado a entrar no mundo dela. Já o outro personagem - Wilhelm - (Movimento Em Falso), mesmo após sair de casa com a intenção de buscar vivências para poder escrever um livro, também não faz muita questão de se relacionar com as pessoas e os lugares por onde passa. No filme, temos vários exemplos disso. Ele prefere olhar tudo com um certo distanciamento, como se aquelas pessoas e lugares fossem apenas um acaso, nada que valesse muito a pena conhecer ou se aprofundar. Já no último filme analisado, o personagem Bruno Winter (No Decurso do Tempo) estabelece um diálogo nas cenas iniciais com um senhor, ex-projecionista, e simpático ao nazismo, talvez, com a intenção de correlacionar esse estranhamento entre um momento absurdo da História e a própria História do Cinema, no decorrer do filme. No entanto, mesmo após ouvir tudo o que esse senhor tinha a dizer, Bruno percebe que muita coisa ainda não fazia sentido. No fundo, todos os três personagens principais dos filmes de Wenders (Philip, Wilhelm e Bruno) são viajantes que tentam não se comportar como turistas porque desejam ver, escutar e respeitar aqueles que cruzam o seu caminho, no entanto, o ato de viajar supõe uma troca, uma vivência, uma experienciação, mas, muitas vezes esses mesmos personagens se fecham em seus mundos e permanecem na incomunicabilidade.

No fundo, sempre fomos atraídos por viagens, novos percursos, deslocamentos. Viajar é sinônimo de deixar para trás. Viajar, também, é encarar de frente questões fundamentais que envolvem o nomadismo, os movimentos, a transitoriedade, o romper

\footnotetext{
${ }^{5}$ Idem. p. 399.
} 
fronteiras e a pulsão pela errância que, desde sempre, nos instigou. $\mathrm{O}$ viajante é um aventureiro, aquele que parte "em busca de um horizonte que nada limite" (PEIXOTO apud MOREIRA, 1987, p. 81), num percurso em que determinados valores culturais são relevantes para determinar tanto o trajeto quanto o destino buscado ou, mais ainda, a identidade de quem procura algo vago como um destino desconhecido.

Para Alain de Botton (2012, p. 17), se as nossas vidas são dominadas pela busca da felicidade, talvez poucas atividades revelem tanto a respeito da dinâmica desse anseio - com toda a sua empolgação e seus paradoxos - quanto o ato de viajar. Seja de carro, trem, navio ou avião, a importância da viagem está além do percurso. A narrativa cinematográfica soube aproveitar toda a atmosfera dessa trajetória para suscitar os questionamentos mais diversos ao espectador. Filmes de viagem, por exemplo, fazem com que pensemos em questões metafísicas sobre o significado e o propósito da vida. Por meio do filme Alice nas Cidades (1974), pegaremos carona com o primeiro filme de relevância na carreira do cineasta e, a partir dele, iniciaremos o percurso pela análise de algumas cenas desse filme e a busca de possíveis respostas que ele pode nos dar: viajar é descobrir o novo ou, simplesmente, ir em busca de um lugar para esquecer um passado? Será que a fotografia (a imagem em geral) pode substituir as relações de afeto? A transição entre as linguagens, assim como as viagens, se dão por meio de paisagens transitórias da contemporaneidade? Carregamos, ao longo da vida, a identidade do nosso lugar de origem? Ou somos, apenas, a somatória das nossas vivências, experiências e dos lugares por onde passamos? Será que estamos rompendo os vínculos com nosso passado e nossas histórias, com o nosso futuro e nossos sonhos?

Assim como um simples desejo de entrar no carro, ouvir um som predileto, colocar gasolina no posto mais próximo, acender um cigarro e sair pela estrada, o argumento do filme Alice nas Cidades, inicialmente, também evoca uma simplicidade. Podemos resumi-lo da seguinte forma: a história se desenvolve a partir do confronto entre um personagem adulto, um repórter frustrado que se transforma em uma espécie de fotógrafo errante, que descobre a paisagem dos Estados Unidos, e uma criança, Alice, menina que perdeu a mãe e está em busca de seus parentes, da sua identidade e do seu passado. A falta de raízes e a crise de identidade são os fios que vão compor o tecido virtuoso de um novo recomeço. Talvez o recomeço de um resgate de identidade entre um Alemão que viaja para os EUA na tentativa de saber melhor quem ele é, de ver 
um mundo que ele apenas conhece, vagamente, mas busca, de alguma forma, descobrilo no seu próprio vagar. De um turista ensimesmado que pretende, aos poucos, deixar os medos e receios de lado para descobrir novas pessoas, novos lugares e, por fim, se lançar, se (re)conhecer, assim como um viajante dos road movies que faz da estrada uma mera desculpa para se lançar no inesperado, no inefável, nos caminhos tortuosos e desconhecidos de qualquer viagem.

Neste filme, Wenders inicia a sua trilogia de road movies. A principal característica desses filmes é que se passam em viagens e recuperam um ramo da literatura que eclodiu nos anos 60: a beat generation de On the Road de Jack Kerouac (repleto das sonoridades das ruas, das planícies e das estradas americanas) e um ramo do próprio cinema onde Easy Rider (1969) de Dennis Hopper (um marco na filmografia de contracultura) e o magistral Zabriskie Point (1970) de Michelangelo Antonioni (uma viagem de dois jovens pelo deserto da Califórnia) figuram como maiores referências.

Podemos dizer que o gênero desses filmes tem muito a ver com um mergulho no desconhecido, com a jornada de descoberta; e são parentes da literatura de aventura. Em certa medida, são expressões contemporâneas do romance de formação (STRECKER, 2012, p.25). Chamado pelos alemães de Bildungsroman, esse termo aponta tanto para o estabelecimento do romance como gênero "digno", quanto para o processo de aperfeiçoamento do indivíduo burguês nas circunstâncias peculiares do processo histórico e político da Alemanha dos últimos trinta anos do século dezoito. O termo teria sido empregado pela primeira vez em 1803, pelo professor de filologia clássica Karl Morgenstern, em uma conferência sobre "o espírito e as correlações de uma série de romances filosóficos". Mais tarde, em conferência de 1820, o mesmo Morgenstern associará o termo por ele criado ao romance de Goethe Os anos de aprendizado de Wilhelm Meister (Wilhelm Meisters Lehrjahre, 1795-1796), cunhando assim a fórmula paradigmática de definição do gênero. Esse mesmo romance serviu de inspiração para o escritor e amigo de Wim Wenders, Peter Hanke, adaptá-lo com um roteiro bastante livre no seu Movimento Em Falso (Falsche Bewegung, 1975), conforme veremos adiante:

[Tal forma de romance ] poderá ser chamada de Bildungsroman, sobretudo devido a seu conteúdo, porque ela representa a formação do protagonista em seu início e trajetória em direção a um grau determinado de perfectibilidade [...]. Como obra de tendência mais geral e mais abrangente da bela formação do homem, sobressai-se [...] Os anos de aprendizado de 
Wilhelm Meister, de Goethe, obra duplamente significativa para nós, alemães, pois aqui o poeta nos oferece, no protagonista e nas cenas e paisagens, vida alemã, maneira de pensar alemã, assim como costumes de nossa época. ${ }^{6}$

O road movie é um gênero, relativamente, universal e atemporal. Os filmes mais interessantes desse gênero são aqueles em que a crise de identidade do protagonista da história reflete a crise de identidade de uma cultura, de um país. A chave ficional serve também de metáfora para uma sociedade à procura de uma identidade própria. Vale ressaltar que o próprio Wim Wenders tem, na sua origem, uma mãe holandesa e um pai alemão. Ele sempre foi um apaixonado pela cultura americana e, posteriormente, japonesa, mas em qualquer lugar que ele vá, pelas entrevistas que lemos e mencionamos adiante, sempre se sentiu um estrangeiro, um alemão aculturado.

Segundo Wenders (apud STRECKER, 2012, p. 69), nos road movies, você precisa se expor, não é possível se esconder. Você vive uma aventura, deve estar preparado para viver. O início dessa aventura se deu por meio dos filmes westerns. $\mathrm{O}$ cineasta nos confidenciou isso no documentário Janela da Alma. ${ }^{7}$ Disse que os filmes atuais, ao contrário dos filmes do John Ford, não permitem que o espectador pense. Ao assistir um plano, você logo imagina qual será o plano seguinte. Nos westerns, com seus longos planos abertos e silenciosos, entre um plano e outro, o diretor deixava um espaço para o espectador pensar. Hoje em dia, para ele, os planos já estão cheios de significados. De alguma forma, isso significa subestimar a inteligência do espectador. Para entendermos as idiossincrasias do cineasta, teremos que mergulhar um pouco na sua biografia.

Wenders, antes de se tornar cineasta, foi pintor e fotógrafo. Conforme veremos adiante, isso se reflete no cuidado dos seus enquadramentos e também na escolha dos lugares e espaços onde ele costuma filmar. A fotografia, muitas vezes, também serviu de pretexto para ele iniciar uma história. A partir de uma única imagem, o cineasta buscou inspiração para alguns de seus filmes. Antes de começar a filmar o No Decurso do Tempo (1976), Wenders tinha acabado de ultrapassar um caminhão na autoestrada. Fazia muito calor e aquele caminhão não tinha ar-condicionado. Dois homens estavam

\footnotetext{
6 MAAS, Wilma Patricia Marzari Dinardo. "O romance de formação no Brasil. Modos de apropriação". (Unesp) Disponível em http: //www. caminhosdoromance.iel.unicamp.br Acessado em 20.01.2015

${ }^{7}$ Produzido e dirigido em 2001 pelo cineasta João Jardim e o diretor de fotografia Walter Carvalho.
} 
lá dentro sentados, o motorista estava com a porta aberta e deixava a perna para fora, para se refrescar. Esta breve imagem, vista apenas de passagem pelo canto do olho, o impressionou. Daí ele parou, por acaso, em um hotelzinho, onde o caminhão também tinha parado. Wenders foi até o balcão e lá estavam os dois homem do caminhão. Percebeu que eles não trocavam palavra alguma, pareciam não ter nada em comum. Teve a verdadeira impressão de que eles não se conheciam. Diante dessa imagem, se perguntou: como é que vêem? O que é que vêem nas suas travessias pela Alemanha? Logo em seguida, surgiu um filme (WENDERS, 1990, p.80). E, pelo visto, quase sempre, foi assim. Quando ele fez o seu primeiro filme (um curta-metragem), só tinha interesse em "retratos paisagísticos". O seu primeiríssimo filme, Silver City, consistiu em dez planos, durando cada um três minutos: tanto quanto durava uma bobina de $16 \mathrm{~mm}$ para luz natural. Via-se, em cada plano, uma paisagem urbana. Ele não movia a câmera e nada acontecia (WENDERS, 1990, p.74). O próprio protagonista do filme Alice nas Cidades é um jornalista que sofre um bloqueio em relação ao texto e só consegue se comunicar através das imagens. No início do filme, na mais completa solidão, Philip Winter pega a sua câmera polaróide e começa a fotografar o mar. No entanto, não se satisfaz com as imagens que vê. Seria como se elas ainda não representassem uma totalidade. São imagens estáticas, sem sons. De uma maneira poética, Wim Wenders nos pede para prestar atenção na força imagética do cinema, na amplitude dos seus significados. Por meio das imagens fotográficas feitas pelo personagem, o cineasta reforça a densidade da linguagem do cinema com os seus movimentos de câmera, na escolha dos ângulos, no tempo que ela capta cada imagem, na companhia das paisagens sonoras, tudo com a intenção de nos ajudar a acompanhá-lo nessa viagem, a entender melhor quem, de fato, ele é, além de tentar compreender a sua maneira se comunicar, ao menos, por meio das imagens.

A escolha dos três elementos que vão nortear essa tese - viagem, identidade e incomunicabilidade - se justifica pela existência desses temas, de maneira premente, na obra do cineasta, mas também por eles se (inter)relacionarem com algumas questões contemporâneas que foram apresentadas por diversos autores, entre eles, destacamos alguns logo abaixo.

Zygmunt Bauman e aquilo que ele chamou de "modernidade líquida" são uma primeira referência para decifrar os filmes de Wenders. Neste tempo de total fluidez, as 
relações afetivas ou sociais, seguem o padrão da Física: “fluem”, "escorrem”, “esvaemse”, “respingam”, “transbordam”, "vazam”, “inundam”, "borrifam”, "pingam”, são "filtradas"ou "destiladas". Podemos, inclusive, associar "a leveza" ou "ausência de peso" dos fluidos a uma certa mobilidade ou inconstância. Afinal de contas, quanto mais leve viajamos, com maior facilidade e rapidez nos movemos (BAUMAN, 2001, p.8). Bauman se preocupa, particulamente, com a fluidez da identidade nos tempos atuais. Em nossas análises, percebemos o quanto a visão dele se aproxima das personagens de Wenders. Conforme veremos, todos esses viajantes levam poucas bagagens, mas muitas histórias que deixaram para trás. Sem muita nostalgia, buscam uma nova possibilidade de futuro e, ao mesmo tempo, não se preocupam em manter laços afetivos com o passado. A sensação que temos é que a vida desses personagens gira em torno da errância, de um mero deambular.

Norval Baitello Jr. (2005) é outro autor que nos ajudará a decifrar essa jornada. No livro organizado por ele, Os Meios da Incomunicação, encontramos diversos artigos que retratam as múltiplas formas como a incomunicabilidade se apresenta: nas maneiras de se relacionar, no silêncio e nos entremeios da cultura e da linguagem, na mídia, na loucura, na imagem, nas temporalidades, na visibilidade da cultura contemporânea, na solidão e no amor. Ele ainda fala, também, do indizível, do inefável. Esses que são objetos das coisas místicas, da poesia e da arte.

Ciro Marcondes Filho também será de grande valia para pensarmos a incomunicabilidade relacionada aos vínculos afetivos. Falar da incomunicabilidade dos gêneros é falar da impossibilidade de homens e mulheres saberem o que se passa no interior de cada um, da inviabilidade estrutural da comunicação, qual seja, da improbabilidade humana de se conhecer efetivamente o outro (MARCONDES FILHO, 2010 , p.7). Nos filmes que analisamos, percebemos o quanto o cineasta tenta elucidar, por meio dos diálogos e das imagens, algumas diferenças entre os gêneros, mas o quanto elas, ao longo do tempo, passam a se misturar numa espécie de fusão. Suas personagens femininas são mais objetivas, diretas, analíticas, racionais, enquanto seus personagens masculinos são cheios de dúvidas, inquietações, receios, melindres. No entanto, isso pode ser apenas uma idiossincrasia do próprio Wenders. É certo que jamais saberemos o que se passa dentro da cabeça do outro, de que maneira a entonação da nossa voz ou o significado de certas palavras rebatem na consciência do outro, como 
esse outro recompõe internamente frases, situações, vivências estéticas, literárias, tecnológicas. Temos que pensar, também, que sentimentos, vivências e traumas são incomunicáveis diante daquilo que se espera de uma comunicabilidade convencional. Uma outra premissa indispensável que será analisada ao longo desse estudo é que homens e mulheres são diferentes e é nessa diferença que se constitui uma possibilidade de comunicação. Comunicação a partir do estranhamento do outro, na percepção de sua total impenetrabilidade, de seu caráter insólito, singular, diverso, dessemelhante, rebelde, dissidente, heteróclito. É no mistério do outro que se encerra a grande chance da comunicação entre os seres, no reconhecimento dessa diversidade, na aceitação dessa distinção e no ato de querer incorporar, vivenciar, ser objeto desse discordante, com o qual se partilha uma experiência comum, uma vida (MARCONDES FILHO, 2010, p.9).

Os lugares por onde as pessoas transitam também dizem muito sobre elas. Marc Augé, na verdade, vai nos ajudar a pensar o conceito de não lugar. Se um lugar pode se definir como identitário, relacional e histórico, um espaço que não pode se definir nem como identitário, nem como relacional, nem como histórico definirá um não lugar (AUGÉ, 2010, p. 73). Estradas, "meios de transporte" (carros, aviões, trens, ônibus), aeroportos, rodoviárias, ferroviárias, hotéis, parques são exemplos de não lugares ligados à individualidade solitária, à passagem, ao provisório e ao efêmero. O viajante, por si só, é um arquétipo desse não lugar. Ele percorre, muitas vezes, sozinho essas estradas, se depara com placas de sinalização cheias de obviedades, escuta um rádio com músicas conhecidas e pára em postos de gasolina de um não lugar que ele reconhece. Inspirado em seu pintor predileto, Edward Hopper, conforme veremos adiante, Wenders filmou em muitos desses não lugares. Além da própria estrada que serve de fio condutor da narrativa, veremos alguns planos dos filmes ambientados em postos de gasolina, motéis, lanchonetes, aeroportos etc.

A questão da identidade também é fundamental, como vimos com Bauman. Tentaremos, ao longo desse estudo, buscar possíveis respostas para essa "crise de identidade" que estamos vivendo. Conforme argumentado por Stuart Hall (1997, p.8), as identidades modernas estão "descentradas", isto é, deslocadas ou fragmentadas. Assumimos identidades diferentes em diferentes momentos da vida. O sujeito pósmoderno não tem uma identidade fixa, essencial ou permanente. Somos seres contraditórios, fragmentados, híbridos, somos indivíduos que perderam uma ancoragem 
estável no mundo social. Mais uma vez, a viagem, "o passageiro" em deslocamento, o mero ato de flanar vai nos ajudar a decifrar, por intermédio das análises dos filmes de Wenders, a nossa "identidade transitória" que tenta se firmar no instantâneo das imagens, no significado das palavras, na força dos gestos ou na contemplação do silêncio. Os personagens principais dos três filmes a serem analisados são homens inquietos com as suas identidades e a maneira como lidam com as representações delas. Philip Winter, conforme mencionamos, é um repórter alemão que resolve viajar para os EUA na tentativa fracassada de escrever uma reportagem para uma revista. No entanto, o máximo que ele consegue é fazer um apanhado de fotografias que, a seu ver, não reproduzem com fidelidade aquilo que ele julga ter fotografado. Suas imagens, silenciosas e poéticas, registram apenas uma parte de uma totalidade. Já o personagem que representa a tentativa de ser um escritor, um narrador das suas próprias histórias no filme Movimento em Falso, não passa de um homem imaturo, em conflito com o mundo, com uma extrema dificuldade de se relacionar com a sua mãe ou com quem quer que seja. Por isso, passa a ser um deambulante, um flâneur que percorre algumas cidades no interior da Alemanha, em busca de uma escrita de si mesmo. E, por fim, não sabemos quase nada sobre a origem do personagem Bruno Winter, do filme No Decurso do Tempo, apenas que se trata de um projecionista que vive sozinho com o seu caminhão de mudança pelas estradas, com o objetivo de visitar antigos cinemas que ainda resistem ao tempo e, também, de resgatar a história de um cinema quase em decadência. No fundo, todos esses personagens têm muito em comum, principalmente, a questão da identidade em crise. Temos um repórter que não consegue escrever, mas prefere fotografar; um escritor em conflito com a própria vida que acaba por travar o seu texto, e, ainda, um projecionista que vivencia a crise do próprio cinema com suas salas em extinção.

\section{Por que analisar certos filmes?}

Filmes são fotografias que falam. O cinema é uma forma na qual e pela qual um artista pode exprimir o seu pensamento, por mais abstrato que seja. Analisar um filme é o mesmo que decompor esse mesmo filme. De acordo com Vanoye e Goliot-Lété (2012, p.21), é também situá-lo num contexto, numa história. E, se considerarmos o cinema como arte, é situar o filme em uma história das formas fílmicas. Normalmente, dizemos 
que esse processo implica duas etapas importantes: em primeiro lugar decompor, ou seja, descrever e, em seguida, estabelecer e compreender as relações entre esses elementos decompostos, ou seja, interpretar. A decomposição recorre aos conceitos relativos à imagem. No cinema tudo tem um significado. Enquadrar significa colocar elementos (pessoas, objetos e cenários) dentro do quadro. Em cada enquadramento, o diretor de um filme, junto com o diretor de fotografia, pensa na composição. Ela se dá na maneira que essas pessoas, objetos e cenários surgem diante do quadro, a forma como ele se organiza. O ângulo em que a câmera capta a imagem também tem uma importância fundamental. Por exemplo, se o personagem é enquadrado de baixo para cima, ele assume uma posição de relevância dentro do quadro. Já se ele é enquadrado de cima para baixo, há uma espécie de achatamento, é como se o personagem ficasse acuado.

É fundamental, também, analisarmos toda a relevância do som e a atmosfera sonora que ele nos traz. Numa primeira análise, ao observarmos o processo de produção dos componentes sonoros de um filme podemos distinguir: ${ }^{8}$

Diálogos: quase sempre gravados posteriormente em estúdio especialmente em cenas de exterior.

Efeitos Sonoros: tipicamente subdivididos em duas categorias: a paisagem sonora e os efeitos especiais.

Música: elemento criado com o objetivo de conduzir emocionalmente a audiência.

No entanto do ponto de vista de análise do discurso sonoro como forma de expressão, temos as seguintes mensagens correlacionadas ao som do filme:

Na publicação "Teaching the Sound Track" de Novembro de 1976, Claudia Gorbman (Apud BARBOSA) ${ }^{9}$ propôs uma classificacão para os elementos sonoros em cinema na perspectiva narrativa, segundo a qual o som pode ser diegético, não diegético ou meta diegético.

\footnotetext{
${ }^{8}$ Texto extraído do site: http://www.abarbosa.org/docs/som para ficcao.pdf. Acessado em 15/03/2015.

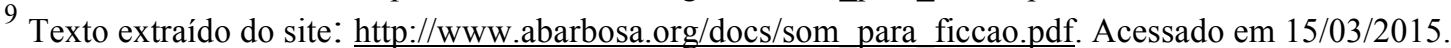


Som Diegético: sonoridades objetivas; todo o universo sonoro que é perceptível pelos personagens em cena, tais como a paisagem sonora (o som dos carros numa cidade, o ruído de uma multidão, os pássaros no campo, a música num bar, etc), ou o diálogo entre personagens. Os sons diegéticos podem decorrer dentro do enquadramento visual da cena ou não (on screen / off screen).

Som não Diegético: sonoridades subjetivas; todo o som imposto na cena que não é percepcionado pelos personagens, mas que tem um papel muito importante na interpretação da cena, ainda que de uma forma quase subliminar para a audiência; sons não diegéticos são tipicamente, voz de narração, música de fundo ou efeitos sonoros especiais.

Som Meta Diegético: sonoridades subjetivas; sonoridade que traduz o imaginário de uma personagem normalmente com o seu estado de espírito alterado ou em alucinação.

Quanto à estrutura de um filme, podemos analisar os seus planos, cenas ou sequências. Chamamos de plano (em inglês, "shot") tudo que é mostrado para o espectador de forma contínua, isto é, como uma sucessão de imagens em movimento sem interrupção de qualquer tipo. A cena (em inglês, "scene") é um conjunto de planos que acontecem no mesmo lugar e no mesmo momento. Já a sequência é um conjunto de planos (ou cenas) que estão interligados pela narrativa. O lugar pode variar, mas a ação tem continuidade lógica (AUMONT, 2004, p. 107).

O objetivo da análise é, então, o de explicar/esclarecer o funcionamento de um determinado filme e, ao mesmo tempo, propor uma interpretação. Trata-se, acima de tudo, de uma atividade que separa, que desune elementos. E após a identificação desses elementos é necessário perceber a articulação entre os mesmos. Em seguida, é feita uma reconstrução para perceber de que modo esses elementos foram associados num determinado filme. Não se trata de construir um outro filme, é necessário voltar ao filme tendo em conta a ligação entre os elementos encontrados. O filme é o ponto de partida para a sua decomposição e é, também, o ponto de chegada na etapa de reconstrução. Este segundo movimento em direção ao filme evita cair em interpretações despropositadas ou pouco pertinentes. 
Para Joly (1996, p.55), considerar a imagem como uma mensagem visual composta de diversos tipos de signos equivale a considerá-la como uma linguagem e, portanto, como uma ferramenta de expressão e comunicação. Seja ela expressiva ou comunicativa, é possível admitir que uma imagem sempre constitui uma mensagem para o outro, mesmo quando esse outro somos nós mesmos.

Ressaltamos aqui a busca pelas representações e identidades que o cinema propicia. Montoro (2006, p.20) enfatiza que problematizar as representações e identidades que o cinema constrói significa, portanto, pensar sobre a construção de um imaginário, apontando a(s) forma(s) como a sociedade e seus grupos são representados pela linguagem audiovisual, repleta de ambigüidades, polissemias e contradições.

Segundo Aumont (2004, p.34), de maneira geral, a análise do filme utiliza principalmente três tipos de instrumentos:

a) instrumentos descritivos, destinados a atenuar a dificuldade de apreensão e memorização do filme. Tendo em conta o predomínio do filme narrativo, muitos desses instrumentos pretendem descrever as maiores (ou menores) unidades narrativas; mas costuma ser interessante descrever determinadas características da imagem, ou da banda sonora;

b) instrumentos citacionais, que desempenham um pouco a mesma função que os anteriores (= realizar um estado intermediário entre o filme projetado e o seu exame analítico minucioso), mas conservando-se mais próximos da "letra" do filme;

c) por fim, instrumentos documentais, que se distinguem dos precedentes por não descrever ou citar o próprio filme, mas juntar ao seu tema informações provenientes de fontes exteriores a ele.

De maneira específica, a escolha desses três primeiros road movies dirigidos por Wim Wenders se dá pela possibilidade de analisarmos alguns conceitos chave sobre as imagens contemporâneas, sobretudo o cinema, que surgem nessas paisagens transculturais. Algumas marcas culturais e identitárias transitam por esses espaços junto com os personagens: experiências de estrangeiridade, ambivalência, estranhamento, nomadismo, desenraizamento e incomunicabilidade. 
No primeiro filme - Alice nas Cidades, vamos nos aprofundar em algumas metáforas visuais utilizadas por Wenders a fim de demonstrar a representação de espaços em trânsito. Nos road movies, a estrada é uma representação de um modus vivendis que atravessa a cultura americana. É o olhar inquieto e estrangeiro com que Wenders percebe os EUA. Mapas, cidades, lugares, aeroportos, hotéis, lanchonetes, postos de gasolina; essas paisagens urbanas (não lugares) são tentativas de pontos de ancoragem desses personagens errantes, em pleno deslocamento. Em um movimento contrário, a fotografia, por exemplo, é utilizada como uma escolha e assimilação do seu caráter estático. Ela está na fronteira entre o instantâneo e a transitoriedade da linguagem. Será um ponto de partida para adentrarmos na esfera do cinema. No entanto, veremos que se há indícios de que a imagem estática (fotografia) já não basta, a imagem em movimento (cinema) na nostalgia do diretor pode, e deve, complementar essa busca de sentidos. Nesse filme, a estrada não é apenas uma metáfora da vida, mas do próprio porvir da linguagem sintagmática do cinema.

No segundo filme, Movimento em Falso, veremos como esse road movie nos leva em direção a um cinema contemplativo. A incomunicação, a solidão e o silêncio estão presentes nesse movimento de interiorização. Por meio deste filme, destacaremos a representação da subjetividade no cinema - como esses aspectos não tinham sido mencionados antes, nos seus objetivos iniciais, associe o cinema contemplativo a a representação da subjetividade no cinema aos seus temas principais: incomunicabilidade, road movies, busca de identidade. Nele, Wenders se deixou levar pelas inspirações estéticas dos seus tempos de cineclube: Godard, Pasolini, Tarkovsky e Bresson serão referenciados como pontos de partida de um cinema que foge das linhas da TV e dialoga, cada vez mais, com a literatura e as suas entrelinhas.

Já no último filme dessa trilogia - No Decurso do Tempo, analisaremos a questão da identidade e o quanto ela está interligada às questões pós-modernas. As crises das personagens, de certa forma, se assemelham às crises que ainda hoje estamos vivenciando: os excessos de palavras e a incomunicabilidade, as crises entre homens e mulheres, o desejo de pertencimento, a revolução digital e a cultura como um espaço de representação. Mais uma vez, a viagem serve como uma espécie de fio condutor para nos aproximarmos da narrativa de um cinema poético que insiste em existir apesar de toda a evolução digital. 
Ao término da análise desses filmes, pretendemos demonstrar como os temas propostos para cada filme estão interligados de tal forma a definir não só uma temática importante na obra de Wim Wenders que dialoga, constantemente, com a atualidade, como uma maneira particular de fazer cinema.

$\mathrm{Na}$ busca do significado desses filmes (road movies) e, consequentemente, das suas representações, faremos uma pesquisa qualitativa para decodificar as marcas do discurso fílmico também nos livros, artigos, periódicos e sites, além de algumas entrevistas audiovisuais, e da análise das principais cenas dos filmes mencionados acima, que são objetos desta tese.

É importante frisarmos que a análise dos elementos da linguagem fílmica que faremos aqui estará subordinada aos três temas apresentados inicialmente: viagem, identidade e incomunicabilidade. $\mathrm{Na}$ abordagem do objeto desta pesquisa, vamos recorrer também aos Estudos Culturais. O que diferencia os Estudos Culturais das demais teorias é a recusa em definir a cultura de forma isolada de outras dimensões da vida social. Os Estudos Culturais pertencem a uma vertente sócio-cultural dentro da grande área de pesquisa que é a Comunicação. Esta perspectiva encontra-se na fronteira entre as Humanidades e as Ciências Sociais. É por isso que o uso da interdisciplinaridade torna-se tão vital para uma pesquisa como esta. Inicialmente, buscaremos entender o que se passa no cinema, para assim entender a "realidade" que nos rodeia.

De acordo com Escosteguy (2004), o coletivo de pesquisadores do Centre for Contemporary Cultural Studies (CCC), originado na Universidade de Birmingham (Inglaterra), analisa as práticas culturais simultaneamente com as formas materiais simbólicas. O grande salto deles foi começar a pensar no leitor como produtor de sentido e não apenas um objeto submetido aos efeitos de uma ação comunicativa externa. As representações, os textos, os discursos estariam diretamente relacionados a certos mapas de significados que permitiriam aos agentes sociais interpretar, conhecer, reconhecer, contestar e agir no mundo social (GIRARDI JR, 2007).

O terreno da investigação proposta por Hoggart, Williams, Thompson e Hall circunscreve-se aos temas vinculados às culturas populares e aos meios de comunicação 
de massa e, posteriormente, às temáticas relacionadas com as identidades, sejam elas sexuais, de classe, étnicas, geracionais etc.

O que os une é uma abordagem que insiste em afirmar que através da análise da cultura de uma sociedade - as formas textuais e as práticas documentadas de uma cultura - é possível reconstituir o comportamento padronizado e as constelações de idéias compartilhadas pelos homens e mulheres que produzem e consomem os textos e as práticas culturais daquela sociedade. É uma perspectiva que enfatiza a "atividade humana", a produção ativa da cultura, ao invés de seu consumo passivo (ESCOSTEGUY apud STOREY, 1997, pág. 46).

Vale a pena frisarmos que Cultura e Comunicação são categorias que apresentam graus de generalidade semelhantes, capazes de abranger quase tudo o que existe no mundo social. Os Estudos Culturais serão importantes para nos ajudarem a identificar nesses produtos culturais (filmes) elementos que definem uma sociedade, seus limites, restrições, determinações, angústias, as suas formas simbólicas e como elas transmitem valores de uma sociedade ou de um segmento dela.

Devemos dizer, também, que no ponto de encontro entre os meios de comunicação de massa e Estudos Culturais, há uma forte inclinação em refletir sobre o papel desses meios de comunicação na constituição de identidades, sendo esta última a principal questão desse campos de estudos na atualidade. Em seus filmes, Wim Wenders compartilha dessa idéia. A escolha das suas paisagens não são aleatórias. Elas reforçam a identidade de um viajante alemão que tenta ser assimilado por uma cultura estrangeira. A critica que ele faz aos meios de comunicação (televisão, rádio e publicidade) e a forma como os personagens tentam assimilar a força e o uso da fotografia também reforçam a constituição de uma identidade cultural, como veremos adiante.

Zygmunt Bauman também nos ajuda a pensar sobre esse processo de individualização que ele vê mais como um egoísmo nocivo do que uma sadia necessidade de identidade (BAUMAN 2001, p. 23). Essa atualidade, a qual ele chamou de "modernidade líquida", é uma modernidade que desmaterializa com tudo que é sólido ou hegemônico, que vem ruindo com certas necessidades materiais e culturais do 
homem, mas que valoriza, sobremaneira, o desejo de sentir-se livre; livre de cercas, barreiras ou fronteiras fortificadas. Por ora, essa falsa sensação de liberdade gera, muitas vezes, a incomunicabilidade. Com isso, modificam-se as relações sociais e a maneira do homem ver e experimentar o mundo. Para ele, a sociedade moderna existe em sua atividade incessante de "individualização". Ou seja, há um desejo, inerente, de "quebrar a forma". Homem sensíveis e mulheres fortes, por exemplo, são personalidades cada vez mais corriqueiras na esfera social. Os seres humanos não mais "nascem" em suas identidades. Mas, ao longo das suas vivências, passam a se tornar aquilo que já são. No entanto, esse "reconhecimento" é dado pelo outro. Isso pode ser considerado uma característica da vida moderna. Os meios de comunicação, ao seu modo, atuam como uma espécie de atalho desse espelhamento. Wim Wenders aponta em seus filmes uma postura crítica em relação aos meios de comunicação. Eles atuam como uma espécie de elo entre as pessoas mas, menos por individualizá-las, do que por criarem um repertório em comum. Nos seus road movies o tema da incomunicabilidade pode ser relacionado à solidão ou a esse isolamento crescente como por causa do percurso e da aprendizagem que seus personagens têm que passar rumo a percepção e assimilação do outro.

Para melhor compreensão da estrutura desta tese, os capítulos, a seguir, serão desenvolvidos da seguinte forma:

No capítulo I - Wim Wenders e a poética de um cinema - faremos uma apresentação da biografia do cineasta e, ao mesmo tempo, vamos contextualizá-lo no cinema alemão. Para um melhor entendimento dos seus filmes, será analisada a relação do cineasta com a pintura, a música e a fotografia. Veremos, também, como os conceitos principais desta tese (viagem, identidade e incomunicação) se apresentam, especificamente, na obra dele. No entanto, é preciso ressaltar que os temas se misturam, mas que serão analisados individualmente para maior clareza.

Ao longo do capítulo II, vamos percorrer as origens da literatura de viagem e dos road movies. Veremos quais foram os autores que estudaram esse gênero cinematográfico e como ele se define. Para o melhor entendimento desse tema, vamos analisar o primeiro road movie dirigido por Wim Wenders: Alice nas Cidades (1974). A escolha desse filme se justifica por ter sido o longa-metragem que projetou a carreira do 
cineasta e também por ele introduzir o gênero road movie ao longo da sua filmografia, além das possíveis reflexões que ele nos traz sobre a fotografia, a incomunicação, a viagem e as relações com os meios de comunicação de massa. Gostaríamos de enfatizar que apesar de toda a sua originalidade, Wenders dialoga com um gênero que veio da literatura e foi apropriado pelo cinema de maneira geral, e não somente por ele. Wenders adaptou o gênero à temática da obra dele. A solidez desse gênero, por si só, justifica a importância de defini-lo. No entanto, enfatizaremos também a perspectiva e a construção de um cinema contemplativo.

No capítulo III falaremos sobre a incomunicação e tudo que ela reverbera no mundo contemporâneo: nas linguagens, nos relacionamentos, na forma de ver e sentir. A incomunicação, muitas vezes, apresenta-se como uma espécie de comunicação incompreendida, de "mão única", que elimina as possibilidades interativas que estão na base do processo. Décio Pignatari (2004) referiu-se ao fenômeno da incomunicação que ele denominou "incomunicabilidade" - como um fenômeno que não acontece, um não-evento ou, no máximo, uma ameaça de evento que não pode realizar-se porque ou falta ou sobra objeto sobre o qual informar.

Para entendermos a incomunicação por meio dessas perspectivas, analisaremos o filme Movimento em Falso (1975). Neste filme, Wenders deixa de lado a linearidade do roteiro e se inspira no romance Os Anos de Aprendizado de Wilhelm Meister, de Goethe. Nesse livro, conforme visto antes, Goethe narrou as aventuras do jovem Wilhelm Meister, filho de um casal da burguesia alemã, que, contrariando as expectativas de sua classe e família, que adoraria que ele fizesse carreira no comércio, apaixona-se por uma atriz e decide juntar-se a uma trupe de comediantes, ingressando assim no mundo do teatro. Após muitos encontros e desencontros, Meister se vê às voltas com os mais diferentes extratos sociais, cumprindo uma trajetória que desenha um esplêndido painel da sociedade de seu tempo.

Já em seu filme, Wenders descreve seis dias na vida de Wilhelm. O aspirante a escritor Wilhelm Meister (Rudiger Vogler) deixa para trás sua mãe opressora e sua casa e parte em uma jornada pela estrada. Sem rumo, ele segue sua rota e encontra pelo caminho uma série de personagens interessantes e figuras bizarras. Em busca da solidão 
para satisfazer seu desejo de escrever, Wilhelm encontra um destino para terminar sua viagem: Zugspitze, uma montanha nos Alpes Bávaros, na Áustria. A partir dos deslocamentos da personagem, vamos analisar os silêncios, os monólogos interiores e a contemplação. Neste filme, em especial, o silêncio impulsiona a formação de uma estrutura voltada para o olhar. A literatura se vê nos lugares mais recônditos focados pelas lentes do cinema.

No capítulo IV, abordaremos o tema da identidade. Seguiremos a perspectiva do viajante que parte e, de alguma forma, se torna duplamente estrangeiro: dele mesmo e do seu local de origem. Estamos, de fato, vivendo uma crise de identidade? Em que consiste essa crise? Em que direção ela está indo? Quem somos nós nesta sociedade de identidades tão fragmentadas? Aquilo que foi tão alardeado por Stuart Hall, no início da década de 90, continua ou já fazia sentido nos anos 70, época dos filmes de Wenders? , mais do que nunca, a fazer sentido: o que está em jogo na questão das identidades? Como ser livre em meio a tantos papéis e limitações sociais? De que maneira o cinema está perdendo o território para outras linguagens mais modernas? Existe, ainda, interesse e espaço para um linguagem cinematográfica clássica, com uma narrativa linear? Por que, nestes tempos frenéticos, ainda gostamos de ouvir e ver histórias? Buscaremos, ainda, em Bauman, Lopes e Agamben respostas para decifrarmos essa modernidade líquida que, por ora, se desfaz no coração do mundo contemporâneo.

Neste capítulo, analisaremos algumas cenas do filme No decurso do tempo (1976) que, por meio de um início de amizade entre um técnico de projetores de cinema e um pediatra recém separado que viajam juntos pela Alemanha Oriental visitando alguns lugares inesperados e salas de cinema desativadas, conhecem pessoas e reconstroem as suas vidas. A escolha deste filme também justifica-se pela poesia e sensibilidade das imagens captadas por Wenders que, ao longo das quase três horas de duração do filme, beiram uma espécie de realismo. Essas imagens vão nos permitir pensar na questão da identidade. À medida em que os sistemas de significação e representação cultural se multiplicam, somos confrontados por uma multiplicidade desconcertante e cambiante de identidades possíveis, com cada uma das quais poderíamos nos identificar - ao menos temporariamente (HALL, 1997, p.14). Por aqui, o cinema servirá de elo para um resgate da sua própria identidade em constante transformação. 
Finalmente, no capítulo $\mathrm{V}$, abriremos novas perspectivas de análise com a conclusão. Aqui será investigado como esses três temas - viagem, identidade e incomunicabilidade - se inter-relacionam. O viajante, na sua essencialidade, busca conhecer a si mesmo com todos os riscos.

No Brasil, alguns cineastas que ainda andam de mãos dadas com a delicadeza fazem filmes inspirados nesse gênero consagrado pela literatura e pelo cinema, mas muitos deles também se consideram tributários da cinematografia de Wim Wenders: Cacá Diegues (Bye Bye Brasil/1979), Walter Salles (Central do Brasil /1998 - Na estrada/2012), Marcelo Gomes (Cinemas, aspirinas e urubus/2004 - Viajo porque preciso, volto porque te amo/2009), Karim Ainouz (Céu de Suely/2006), Lírio Ferreira (Árido movie/2006), Charly Braun (Além da estrada/2010).

Todos esses filmes, a sua maneira, se caracterizam por meio dos seus personagens errantes, cheios de dúvidas e indagações, que vagueiam por uma estrada a procura de algo ou alguém. São esses os temas que Wenders tanto ajudou a consolidar na linguagem do cinema, que se repetem, férteis, também na literatura: o rito de passagem, a busca de uma identidade e a procura do desconhecido - a errância.

O cinema de Wim Wenders com opções de roteiros abertos, na hora de filmar e atuar dos personagens, permite a incorporação de novos elementos. De certo modo, seus filmes se inspiram numa estética documental com o objetivo de recuperar o essencial do cinema: humanismo e emoções. Filmes que argumentam sobre o sentido da vida, a dignidade humana e a transcendência; com um olhar sensível, primam por um ponto de vista reflexivo, sem pirotecnias ou artificialismos. Um cinema mais próximo de um real, embora a poesia do cinema esteja na escassez da violência, mas na força da subjetividade que habita o nosso inconsciente e que nos ajuda a exprimir também o mundo dos sonhos, das emoções e do instinto. 


\section{Os principais conceitos que vão nos guiar pelo caminho}

A escolha desse corpus de pesquisa, os três primeiros road movies de Wim Wenders, expressa a impossibilidade de diálogos na era da comunicação, o excesso de imagens que esvazia a realidade imaginária contemporânea, os simulacros e os cenários em ruínas. Seus personagens, embora estrangeiros à nossa cultura, trazem algumas identificações. São, talvez, a melhor descrição dos dilemas de nossos tempos, além de representarem todas as crises possíveis: nas trocas de afetos, nos relacionamentos, nos modos de ser e (con)viver.

Todos esses filmes, na verdade, nos fazem pensar na forma como estamos nos comunicando. Comunicar, à primeira vista, parece um ato natural. Temos uma necessidade, premente, de sermos entendidos. Assim, mesmo sem querer, estamos sempre dizendo algo para alguém; seja através da fala, da entonação da nossa voz, dos gestos, dos nossos movimentos corporais, na escolha das nossas roupas, cores, tecidos e texturas. Tudo, de certa forma, tenta comunicar. O ser humano, por natureza, sempre foi um ser simbólico, ser de linguagem e de comunicação.

Vivemos em uma era em que a comunicação tem um papel fundamental. Comunicar significa dizer algo, de alguma forma, tornar público, contar algo ou alguma coisa, para alguém. Todos os dias, aos sairmos de casa, nos deparamos com uma verdadeira avalanche de signos que gritam e se fazem notar, por todos os lados. Pessoas transitam nas ruas, nos deparamos com várias nuances de cores, formas, texturas, cartazes, palavras, sons, enfim, convivemos com os mais variados tipos de textos e tessituras.

Nessa geléia geral da vida cotidiana, é inegável o poder dos meios de comunicação de massa: rádio, televisão, cinema, vídeo, mídia impressa, internet. Todos, em qualquer tempo, tem algo a dizer. Todos, ao mesmo tempo, querem dizer algo. Muitos, ao mesmo tempo, se pronunciam, poucos ouvem. No entanto, ouvir faz parte do diálogo. Proferimos discursos demais e diálogos de menos. Bohm $(2005$, p. 7) pensa o diálogo como um processo multifacetado, que vai muito além das noções típicas do linguajar e do intercâmbio coloquiais. Dialogar significa tentar compreender a experiência humana por meio dos nossos valores mais intimamente arraigados; a 
natureza e a intensidade ds emoções; os padrões de nossos processos de pensamento; a função da memória; a importância dos mitos culturais herdados; e, por fim, a maneira segundo a qual nossa neurofisiologia estrutura a experiência do aqui-e-agora.

Temos plena consciência que o mundo muda e a informação também. O mundo mítico que se apresentava, hoje é representado. O homem que participava do mundo, por ora, tem o mundo adiante. A palavra que era sopro e corpo, agora é signo e instrumento. A proximidade virou distância. $\mathrm{O}$ experimentar e o sentir se deixou inebriar pelo observar e refletir. Estamos numa época de excessos. Em alguns casos, alimentados pela lógica do consumo. Nessa lógica, poucas imagens se diferenciam de vitrines. Nossos olhos são levados a consumir imagens que se sobrepõem intermitentemente; do mesmo modo, a sedução do instantâneo acaba nos levando a produzi-las, antes mesmo de compreender seu sentido.

Toda essa mudança, em nossa maneira de sentir, pensar e agir, nos faz acreditar que a incomunicabilidade está, cada vez mais, ganhando força e ousadia, provocando estragos, desfazendo e desmontando, distorcendo e deformando, semeando discórdia e gerando falsas expectativas, invertendo sinais e valores, azedando as relações e produzindo estranhamentos incômodos (BAITELLO, 2005, p. 9). Nesses tempos superlativos, com o excesso de informação, excesso de tecnologia, excesso de luz, excesso de zelo, excesso de visibilidade, excesso de ordem, sofremos com a aceleração, o estresse, a pressa e a indiferença para ouvir o outro.

Estamos em plena era do "verticalismo" (Harry Pross). Baitello (2005, p. 10) fala sobre obsessão da vertical transformada em vida e da vida transformada em vertical que impõe a cada um de nós uma luta permanente em direção ao mais alto. No entanto, ele frisa que o mais alto é o nada, o vazio, o inóspito, o inabitável espaço; embora o mais alto seja a condição inalcançável dos deuses e dos seres celestiais imaginários, imateriais, sem corpo e sem humanidade, portanto, sem vida. Esse verticalismo pode ser pensado como a obsessão mais poderosa do nosso tempo. Seus efeitos são devastadores, por duas razões: a primeira, a demolição da corporiedade e dos espaços que a abrigam. Ou seja, a destruição da realidade tridimensional por meio da transformação dos corpos em abstratos traços verticais. Já a segunda razão é a perda dos vínculos com o outro ser ao lado (uma vez que os vínculos elementares que constituem 
a nossa natureza humana são necessariamente horizontais); isto quer dizer, a renúncia à capacidade de comunicar-se, abrindo os espaços para a livre escalada da incomunicação.

Vilém Flusser (apud BAITELLO, 2005, p. 10) descreveu o processo de perda crescente das três dimensões do espaço de comunicação do homem. Da comunicação corporal, que ocorre em três dimensões, passamos para a comunicação por imagens, em apenas duas dimensões, depois para escrita, composta de traços unidimensionais, e finalmente a comunicação digital, com nenhuma dimensão. E agora, a partir da nulodimensão, começa o homem a reconstruir virtualmente as outras dimensões, conforme alertou Flusser.

Uma pergunta que poderá nos nortear é se essa redução drástica do espaço externo da comunicação, dos vínculos sociais, dos horizontes da sociabilidade, não estará correspondendo a uma redução dos espaços internos, a um estreitamento da comunicação consigo mesmo? Caso isto esteja de fato ocorrendo, estaremos diante de uma dupla manifestação dos efeitos devastadores da incomunicabilidade. Baitello (2005, p. 11) diz que estaremos cortando nossos vínculos com os outros seres e estaremos cortando os vínculos conosco mesmos, vale dizer, estaremos rompendo os vínculos com nosso passado e nossas histórias, com o nosso futuro e nossos sonhos. $\mathrm{O}$ mais inquietante é a pergunta que nos resta: o que fica no lugar dos vínculos rompidos? Ficam os fantasmas dos vínculos. A eles é que damos o nome de "incomunicabilidade".

Além do conceito chave da incomunicabilidade, vamos trabalhar ao longo desta tese com o conceito de identidade. Os personagens dos filmes que serão analisados, de certa maneira, são identificados por nós, nos representam. Para entender melhor esse processo, o nosso ponto de partida será tudo aquilo que foi provocado, inicialmente, por Stuart Hall. Hall (1997, p. 7) disse que as velhas identidades, que por tanto tempo estabilizaram o mundo social, estão em declínio, fazendo surgir novas identidades e fragmentando o indivíduo moderno, até aqui visto como um sujeito unificado. Por isso, estamos vivendo uma chamada "crise de identidade" que culmina em um processo mais amplo de mudança ao deslocar as estruturas e processos centrais das sociedades modernas e, ao mesmo tempo, ao abalar os quadros de referência que davam aos indivíduos uma ancoragem estável no mundo social. Essa crise vem à tona quando algo 
que se supõe como fixo, coerente e estável é deslocado pela experiência da dúvida e da incerteza.

A partir do momento que percebemos que tudo na natureza está em pleno estado de transformação, por que seriam estáticos os papéis sociais? A questão maior, no entanto, não é compreender, mas perceber e aceitar essas transformações. O sujeito pósmoderno, não tem uma identidade fixa, essencial ou permanente. Por sua vez, a identidade torna-se uma "celebração móvel". Algo a ser formada e transformada, continuamente, em relação às formas pelas quais somos representados ou interpelados nos sistemas culturais que nos rodeiam. Hall (1997, p. 9), ainda reforça essa mudança estrutural que está transformando as sociedades modernas, a partir do final do século $\mathrm{XX}$, por meio da fragmentação das paisagens culturais de classe, gênero, sexualidade, etnia, raça e nacionalidade. Tudo que é sólido se desmancha no ar. As identidades modernas estão sendo "descentradas", isto é, deslocadas ou fragmentadas.

Todas essas transformações estão mudando nossas identidades pessoais, abalando a idéia que temos de nós próprios como sujeitos integrados. Esta perda de um "sentido de si" estável é chamada, algumas vezes, de deslocamento ou descentração do sujeito. Buscaremos, também, entender como todos os fenômenos citados acima acontecem em um tempo que chamamos de contemporâneo. Para o filósofo italiano Agamben (2009, p.18), o contemporâneo que se pode entrever na temporalidade do presente é sempre retorno que não cessa de se repetir, portanto, nunca funda uma origem e, com isso, se aproxima da noção de poesia. Na visão dele, a poesia é esse movimento do olhar para trás operado no poema, portanto, um olhar para o não-vivido, no que é vivido, tal como a vida no contemporâneo. Para ele, o voltar-se para trás, suspender o passo, ver o escuro da luz, entrever um limiar inapreensível entre um ainda não e um não mais e compreender a modernidade como imemorial e pré-histórica são algumas das fraturas, das cisões no tempo com as quais o sujeito, o poeta, tem que saber lidar. Em seu pensamento poético, pode dizer-se contemporâneo apenas quem não se deixa cegar pelas luzes do século e consegue entrever nessas a parte da sombra, a sua íntima obscuridade.

Podemos dizer que os filmes que serão analisados partem de uma "razão poética”. O cineasta Wim Wenders é também conhecido como um poeta das imagens. 
Em seu movimentos de câmera, faz questão de explorar alguns travellings de estradas pouco habitadas, e permanentes na sua distância, as longas panorâmicas do deserto no oeste americano e fotografias em ângulos onde a ênfase, muitas vezes, é no céu muito claro e azul, de um azul agressivo mesmo, que explora uma poeticidade quase explícita. Castro e Dravet (2011) nos diz que a essência desse pensar poético tem se expandido para a criação e a produção de imagens da indústria comercial que se defronta, a cada dia, com o inesperado, o desconcerto, a metáfora e a complexidade da poesia. Desde que a produção audiovisual acertou o casamento entre "o real" e a imaginação, instalouse o risco dos diálogos subseqüentes. Para René Char (apud CASTRO e DRAVET), o poeta é aquele que sabe um pouco mais porque sente as coisas, aprende a percebê-las no lugar mais profundo e a deixar-se marcar por elas.

Ainda de acordo com Castro e Dravet (2014, p. 26), Pasolini em seu tratado sobre o cinema de poesia, exposto em 1965, declarou que a essência do cinema é poética. Ele defendeu um resgate à língua da poesia, ao tomar como base recursos literários. Foi ele quem reinterpretou o discurso indireto livre da literatura para o cinema e resolveu chamá-lo de subjetiva indireta livre. Para resumir bem, na literatura, o discurso direto acontece quando o personagem fala em primeira pessoa, já o discurso indireto quando o autor fala pelo seu personagem. Ao seu modo, o discurso indireto livre flexibiliza ou quebra essas fronteiras e nos confunde com a fala do autor por meio de seu personagem. No cinema, a câmera subjetiva se torna o olhar do personagem, o seu ponto de vista. Com a subjetiva indireta livre, há uma quebra de fronteira entre o olhar objetivo e subjetivo, entre o real e o imaginário que compõe o universo retratado. Por sua vez, a câmera vira uma espécie de alterego do diretor, toda a idiossincrasia e o lirismo dele é refletido no estado de alma do personagem. No filme Alice Nas Cidades, por exemplo, a subjetiva indireta livre se dá quando o personagem Philip Winter tenta, freneticamente, mudar a estação do rádio e diz que não há nada para se ouvir. Ou, até mesmo, quando ele fotografa e diz que as imagens nunca representam aquilo que ele viu.

No sentido de compreender a poesia do cinema nos road movies, vale a pena mencionarmos o conceito de viagem. Na verdade, pegaremos emprestado de Cardozo (1987, p. 358) uma possibilidade de significação sobre o ato de viajar. As viagens revelam um inequívoco parentesco com a atividade do olhar. Esta afinidade não vem 
apenas de certos traços de sua operação, ou da economia de seu funcionamento, mas que, umas e outro, revelam-se, finalmente, expressões diversas de uma experiência do tempo. Viajar significa ampliar, intensificar e prolongar o mesmo movimento que fazemos, cotidianamente, ao exercitarmos a experiência do olhar. Viajar, também, pode ser interpretado como uma busca pelo conhecimento. Nessa acepção, o olhar percorre lugares inexplorados, com a mera intenção de saciar uma curiosidade ou descobrir algo. Nesse sentido, viajar é conhecer ou reconhecer.

Precisamos reiterar que os conceitos de incomunicabilidade, identidade, contemporaneidade, poesia e viagens foram apresentados, singularmente, para maior clareza. No entanto, na maioria das vezes, esses temas se misturam, como veremos adiante, além de recorrerem a muitos outros, ao longo da pesquisa.

\section{1 - Wim Wenders e a poética de um cinema}

O documentário produzido pelo Goethe-Institut (2007), intitulado Aquele que saiu à procura - Os primeiros anos de Wim Wenders nos dá pistas fundamentais sobre a biografia, a maneira de pensar, os filmes e a temática recorrente na filmografia desse poeta das imagens. Nessa relação entre cinema e poesia, o olhar percorre um roteiro de enigmas como se adentrasse em um labirinto. Certas zonas de intersecção elegem elementos de ordem estética e filosófica, formal ou temática, e o simples fato de transitar entre elas podem nos fazer chegar a um discurso mimético que nos fará traçar um roteiro de trilhas que nos levam para vários caminhos de reflexão. Segundo Bateson (apud CASTRO e DRAVET, 2011), a metáfora é a lógica sobre a qual o mundo vivo é constituído. E como é linguagem poética, leva e eleva o homem em direção ao mundo e a ele mesmo.

A epocalidade e a geografia também dizem muito sobre o que consideramos, ingenuamente, como imagens idiossincráticas. Wim Wenders, cineasta alemão, nasceu em Dusseldorf, em pleno 14 de agosto de 1945. Podemos dizer, inclusive, que ele nasceu bem no finalzinho da Segunda Guerra Mundial. Alguns acontecimentos, ${ }^{10}$ naquele ano, foram marcantes: no dia 9 de agosto, Os Estados Unidos

\footnotetext{
${ }^{10}$ Informações extraídas do Museu Memorial do Holocausto dos Estados Unidos. Disponível em: http://www. ushmm.org, acessado em 3/5/2013.
} 
lançam uma bomba atômica sobre a cidade de Nagasaki, já no dia 14 de agosto, os japoneses concordam com uma rendição incondicional.

Wim Wenders disse que, de algum modo, não tem como afirmar que isso pode ser considerado como um tema, mas, de certa forma, nos confidencia que em seus filmes existe um certo denominador comum. Com apenas três perguntas, ele sintetiza a sua obra: Como se pode viver num mundo desse? Qual é o sentido da vida? Para que vivemos? Não há como negar que o fato dele ter nascido na Alemanha, bem no fim da II Guerra Mundial, naturalmente o aproximam de questões políticas, existencialistas e ideológicas. O seu "herói" recorrente é alguém que percorre um ambiente hostil. Ele sempre se pergunta como é possível alguém viver em um mundo como o nosso.

Vivemos numa época de poucos sentidos e inúmeros pensamentos diluídos e acelerados. De certo, a resposta a essas questões de Wenders extrapolam os 140 caracteres do Twitter e fogem às banalidades do "o que é que você está pensando?" propagada pelo Facebook e, caso você esbarre com alguém pela rua e resolva, de peito aberto, iniciar uma conversa sobre o sentido da vida, antes de iniciar a frase com um singelo "eu penso que...", o ouvinte desinteressado, com certeza, já dobrou a esquina.

Certa vez, o poeta e filósofo Antônio Cícero (2012, p. 13), disse que não temos mais tempo livre porque o nosso tempo está preso para que sejamos uma espécie de instrumental para outras coisas e pessoas. Assistir a um filme, no caso, é puro deleite ou fruição que, em qualquer tempo, nos faz pensar.

Wenders, antes de se tornar cineasta, abandonou os cursos de medicina e filosofia. A filosofia, no entanto, nunca abandonou a maneira dele questionar-se sob a forma de imagens. Para ele, filmes dizem mais por aquilo que não dizem ou não mostram. Certos filmes lidam com o inexprimível e o invisível, mas, mesmo assim, podem atingir o nosso inconsciente.

De forma diferente, seus filmes são capazes de falar sobre aquelas questões filosóficas pontuadas acima. De acordo com Donata Wenders, sua esposa atual, existem algumas paisagens nas quais ele sente-se confortável. Com uma certa ironia, ela nos conta: 
Tudo que não é verde, acho. Desertos, sob todos os aspectos. Algo de areia e concreto, toda a vastidão. Uma paisagem vazia com uma moita vazia, ele acharia fantástico. Mas também tudo que é urbano ou paisagens urbanas abandonadas. Assim ele cresceu. ${ }^{11}$

As paisagens encheram o olhar de Wenders de sentimentos e indagações. $\mathrm{Na}$ vastidão das paisagens, buscava as respostas sobre o convívio familiar. Nas lembranças de infância, seu pai era muito ocupado e ele e o irmão mais novo, não se recordam de falar muito com a própria mãe. Segundo ele, ela tinha os nervos sensíveis, ficava indisposta com frequência, então eles procuravam poupá-la.

Donata, mais uma vez, relata no documentário que a mãe de Wenders sempre falava bem do seu marido e do seu casamento. No entanto, ela ouviu de outras pessoas, mas nunca dela mesma, que eles brigavam muito. A repressão era total. Ela acredita que tudo isso está enraizado dentro de Wenders. De algum modo, foi passado pelo leite materno.

O que poderia ser uma simples informação sobre alguns hábitos familiares, reforça o que Wenders evidencia nos seus filmes: uma certa solidão acompanhada, de uma mãe próxima, mas ausente. Quando ele diz que

\footnotetext{
Nossa mãe nunca foi tão importante para Klauss e eu, como nosso pai. Ele era nosso ponto de referência. Minha mãe sempre se colocou no papel de dona de casa. Nunca tinha opinião própria. Primeiro escutava o meu pai e adotava sempre a sua opinião.
}

Além da busca pelo pai, a solidão e a incomunicabilidade também acompanharam a sua infância e, adiante, muitos dos seus filmes. Aquilo que poderia ser rotina para alguns, para ele era exceção. Wim conheceu famílias onde todos falam ao mesmo tempo. Na casa de amigos, por exemplo, todos discutiam na mesa. Ele não estava acostumado. Achava divertido que outras pessoas falavam muito. Na família dele não havia esse exemplo. Eles não falavam, muito menos na mesa.

Talvez isso explique um pouco a sua predileção pelo Existencialismo. Essa "filosofia da existência" foi um traço distintivo de todo pensamento moderno: a ênfase no sujeito, não meramente o sujeito pensante, mas nas suas ações, sentimentos e na

\footnotetext{
${ }^{11}$ Fala extraída do documentário produzido pelo Goethe-Institut (2007), intitulado Aquele que saiu à procura. Os primeiros anos de Wim Wenders.
} 
vivência de um ser humano individual. No documentário, ele confessa que Camus foi o seu grande herói. Embora ele não diga, não é difícil entender à predileção pelo escritor franco-argelino que, entre tantas obras, escreveu O Estrangeiro (L'Étranger/1942). Amava-o acima de tudo, mais do que Sartre que, na sua opinião, impressionava mais pelo intelecto.

Antes de se decidir pela carreira de cineasta, Wenders passou um ano em Paris pintando quadros e freqüentando a cinemateca francesa. Chegava a assistir de cinco a seis filmes por dia, sem intervalo. Algumas vezes, se escondia no banheiro e, em seguida, entrava novamente na sala para não precisar pagar um novo ingresso.

Depois voltou para Munique e freqüentou a Universidade de Cinema e Televisão, entre 1967 até 1970.

É considerado como uma das mais figuras mais importantes que surgiu do "Novo Cinema Alemão", na década de 70. Fassbinder, Herzog, Schlöndorff e Wenders ajudaram a criar esse alicerce. ${ }^{12}$

A exigência desses diretores era que os filmes deveriam ser novamente autênticos, contar histórias que tratassem de pessoas "reais" das ruas, como também deveriam ser filmados em locações originais. O grande exemplo era a Nouvelle Vague, que tinha revolucionado o cinema francês pouco antes.

Foi membro fundador da distribuidora de cinema alemão chamada "Filmverlag der Autoren", em 1971. Quatro anos depois, estabeleceu, em Berlim, a sua própria companhia de produção chamada "Road Movies". A maior retrospectiva sobre sua fotografia - "Pictures from de surface of the Earth" - foi exibida em museus e institutos de arte pelo mundo afora (2001). Durante as suas viagens pessoais ou enquanto buscava futuras locações para os seus filmes, Wim Wenders publicou vários livros com ensaios e fotografias: Written in the West (1986), Wim Wenders Photographs (1989), Once Photographs by Wim Wenders (1993), Wim Wenders - Landscape and memory (1996), The heart is a sleeping beauty (1999), Buena Vista Social Club (2000), Journey to Onomichi (2006), Places Strange and Quiet (2010), Pina. The Film and The Dancers (2012).

\footnotetext{
${ }^{12}$ Informação extraída do site http://www.dw.de/novo-cinema-alem\%C3\%A3o-comemora-50-anos/a15787565, acessado em 7/6/2012.
} 
Em 1984, se tornou membro da Academia de Artes de Berlim. Em 89, recebeu alguns títulos de doutor honorário da Universidade Sorbonne, em Paris, da Faculdade de Teologia da Universidade de Fribourg (1995), da Universidade de Louvain (2005) e da Faculdade de Arquitetura da Universidade de Catania (2010). É membro fundador e presidente da Academia de Filme Europeu e da ordem "Pour Le Mérite". Atualmente, leciona cinema na Universidade de Hamburg e mora em Berlim, com a sua esposa, a fotógrafa Donata Wenders.

O nome Wim é de origem holandesa e veio do lado da família da mãe dele. ${ }^{13}$ Embora tenha sido uma escolha dos pais, não pode ser batizado com esse nome porque, de acordo com as autoridades, não era um nome próprio de origem alemã. A sonoridade do nome mais próxima era Wilhelm, daí na sua certidão de nascimento e passaporte o seu nome é Ernest Wilhelm Wenders, Ernest era o nome do seu avô.

Em 1967, quando retornou para Alemanha, trabalhou por um breve período em Dusseldorf, no escritório da United Artists e no outono ingressou na "Hochschule fur Fernsehen and Film" (Escola de Graduação de Filme e Televisão), que acabara de ser fundada em Munique. Rainer Werner Fassbinder foi um dos rejeitados naquela instituição, ficou tão indignado que, desde então, começou a fazer filmes só para mostrar para eles.

Paralelo aos seus anos de Faculdade (1967 - 1970), Wenders também trabalhou como crítico de cinema e assinava a coluna "FilmKritik", no jornal diário de Munique chamado "Suddeutsche Zeitung", e também nas revistas TWEN e DER SPIEGEL.

Durante esse mesmo período, fez vários curtas-metragens e no verão de 1968 foi preso em uma manifestação de protesto contra tentativas de agressão ao Rubi Dutschke - líder estudantil alemão. Por isso, recebeu uma sentença de seis meses e meio de suspensão da faculdade por ter resistido à prisão.

\footnotetext{
${ }^{13}$ Esta informação e toda a cronologia dos trabalhos que citamos abaixo, foi traduzida e retirada do site oficial de Wim Wenders: www.wim-wenders.com, acessado em 6/10/2014.
} 
Em 1971, junto com outros quatorze cineastas alemães, iniciou uma cooperativa de produção e distribuição chamada "Filmverlag der Autoren". Essa companhia se tornou o núcleo do novo cinema alemão.

Nos seus primeiros filmes, interessou-se particularmente por várias manifestações da cultura norte-americana: beatniks, rock, blues, o cinema de Samuell Fuller e John Ford, pelos automóveis (o trailer), os motéis e a estrada. Compõe este ciclo, em primeiro lugar, Alice nas Cidades (1974) em que reinterpretou o gênero road movie sob um ponto de vista pessoal. Foi a partir dele que achou que deixaria de ser um alemão (estrangeiro) para se tornar um americano. No entanto, não foi bem assim que aconteceu, conforme veremos adiante.

Antes de filmar Alice nas Cidades (Alice in den Städten, 1974), estava prestes a largar o cinema. O seu terceiro longa-metragem “A Carta Escarlate” (Der Scharlachrote Buchstabe, 1973) tinha sido uma verdadeira decepção. Aliás, esse foi um dos poucos filmes dele que não aparecem carros e antenas de TV. Ele adaptou o romance clássico $A$ Carta Escarlate, um dos grandes clássicos da literatura americana, de Nathanael Hawthorne (1804-1864). Filmou a história de Hester, que vivia um amor adúltero com o reverendo Dimmesdale e assim foi obrigada a usar na roupa a letra A na cor escarlate. A crítica achou meio entediante essa sua adaptação de um clássico sobre intolerância e paixão.

Depois do trauma do filme anterior, decidiu investir tudo em Alice nas Cidades. $\mathrm{Na}$ faculdade, todos achavam que ele era doido quando planejou um longa-metragem com 15000 marcos. Todos faziam filmes de 10 ou 15 minutos. Ele fez um filme de duas horas e meia com o mesmo orçamento. Iniciou, neste filme, o desejo de questionar as imagens e o cinema dentro do próprio cinema. As relações humanas, os seus fracassos e incompletudes também foram contempladas na trama. A história da menina que é abandonada pela mãe e inicia uma grande amizade com um jornalista que sofre um bloqueio para o texto e só consegue fotografar, ganhou a simpatia do público. É o primeiro filme que ele faz com que as personagens percorram as estradas e deslocam-se entre países em busca das suas identidades.

Não somente as estradas, mas a simplicidade de um argumento frente à complexidade das relações humanas, começam a fazer parte da sua filmografia. No 
decurso do tempo (1976), trata sobre a história de dois homens que, só no final, se definem um em relação ao outro e só no final aprendem um com o outro. E, em seguida, descobrem quem são em relação ao outro; sobretudo, são forçados a aprender como resolver conflitos.

Um dos atores principais do filme (Rüdiger Vogler) disse ${ }^{14}$ que, em alemão, o filme No decurso do tempo chama-se Im Lauf der Zeit. A palavra "Zeit" também significa que um certo Zeitgeist (espírito do tempo) também está presente nesse filme. $\mathrm{Na}$ verdade, ele se refere ao que pode ter motivado Wim Wenders a filmá-lo. Até uma certa idade, complementou Rüdiger, todo mundo já deixou uma mulher, ou já foi deixado e, não sabe como sua vida deve continuar.

Donata, a esposa de Wenders, vai um pouco além nessa afirmação:

Acredito que as mulheres de sua idade, suas iguais, nunca trabalharam em seus filmes. Já falei com ele sobre isso, mas acho que ele teve uma experiência traumática em sua vida. Uma mulher o deixou quando ele era jovem, uma garota. Ela o deixou para ficar com o seu melhor amigo. Pra ele, foi um momento decisivo na sua vida. Não lutou por ela, ficou paralisado, mas não conseguiu fazer nada. ${ }^{15}$

Talvez não seja difícil imaginar que essa experiência o tenha motivado a colocar o pé na estrada e extravasar algumas angústias por meio das imagens e de um filme que começa com a dor de uma separação.

Em 1976, ele iniciou a "Road Movies Filmproduktion Inc.” produtora que, em Berlim, se envolveu, ao longo dos anos, com mais de cem produções e coproduções até 2003. Por vários anos, no início dos anos 80 , Wenders também teve uma produtora em Nova Iorque, junto com Chris Sievernich, chamada Gray City Inc.

Em 1977, terminou $O$ amigo americano, que foi sua primeira co-produção internacional que chamou a atenção de Francis Ford Coppolla. Com esse filme, Wenders carimbou o seu passaporte de cineasta alemão em direção ao caminho mítico da América ${ }^{16}$.

\footnotetext{
${ }^{14}$ Fala extraída do documentário Àquele que saiu a procura. Os primeiros anos de Wim Wenders, produzido em 2007 pelo Goethe Institut.

${ }^{15}$ Idem.

${ }^{16}$ Expressão criada pelo crítico de cinema Cássio Starling Carlos no Caderno Ilustrada - Folha de SP http://www1.folha.uol.com.br/fsp/ilustrad/fq2307200616.htm, Acessado em 10/04/2012.
} 
Em 1978, a convite de Coppolla, foi para os Estados Unidos filmar Hammet para a Zoetrope Productions, que o ocupou, entre outros trabalhos, até 1982.

Durante várias interrupções da filmagem, Wenders fez Lightinig over Water (junto com o seu amigo, o diretor Nicolas Ray) e depois The State of Things, que ganhou o seu primeiro Leão de Ouro no Festival de Veneza de 1982, o primeiro de uma série de premiações internacionais.

No verão de 1982, Wim dirigiu a sua primeira (e única) peça “Andando sobre as cidades" de autoria de Peter Handke para o Festival de Salzburger

Em 1982, ao mudar de Los Angeles para Nova Iorque, Wim iniciou um trabalho de roteiro, junto com Sam Shepard, que havia conhecido em 1978, quando ele pensou em chamá-lo para fazer o papel de Hammet. Desta vez, o estúdio recusou a escolha de Wenders. Em seguida, ele escreveu o primeiro roteiro baseado nas Crônicas de Motel, de Sam Shepard, mas eles decidiram começar apenas com um rascunho. O filme foi rodado no verão de 1983 e, eventualmente, intitulado "Paris, Texas".

Em 1987, publicou o seu primeiro livro de fotografia chamado Written in the West. Fotografou o oeste americano enquanto procurava locações para o filme Paris, Texas. A fotografia sempre teve uma importância fundamental em seus filmes, não só por meio do cuidado rigoroso nos enquadramentos, mas no silêncio questionador que certas imagens evocam e, também, o prenúncio de uma história que está contida nela.

As minhas histórias começam sempre com imagens. Quando comecei a rodar
o meu primeiro filme, me interessavam, exclusivamente, "retratos
paisagísticos". O meu primeiríssimo filme, SILVER CITY, consistiu em dez
planos, durando cada um três minutos: tanto quanto durava uma bobina de
$16 \mathrm{~mm}$ para luz natural. Via-se, em cada plano, uma paisagem urbana. Eu
não movia a câmara e nada acontecia. ${ }^{17}$

Essa inspiração, veio, quase inconsciente, quando rodou Tokyo-Ga, um filme sobre o seu diretor favorito, o grande mestre japonês Yasujiro Ozu. As paisagens transculturais são marcas do seu discurso imagético. Podemos perceber, inclusive, uma certa paixão pelo Oriente e pelas delicadezas da cultura oriental nessa homenagem feita ao Ozu.

Essa tentação de emular Ozu é mais visível em Tokyo Ga, de Wim Wenders (1985), ao buscar não só as imagens dos filmes de Ozu no Japão de 1980, mas iniciar "seu" filme com cenas de Era uma vez em Tóquio, falar com o

\footnotetext{
${ }^{17}$ Wenders. A Lógica das Imagens, Lisboa: Edições 70.
} 
cameraman de Ozu, filmar usando as mesmas lentes que Ozu usava, nos mesmos lugares, e por fim, reencontrar e entrevistar um dos atores mais presentes na cinematografia de Ozu: Chishu Ryu (LOPES, 2012, p. 104).

Alguns anos depois, fez um outro documentário Notebook on Cities and Clothes, sobre o designer de moda Yohji Yamamoto. Sobre este filme, especificamente,Wenders disse que

\begin{abstract}
Sobre o mundo da moda, eu tinha interesse no mundo e não na moda. Mas, talvez, eu tenha sido muito apressado para desconsiderar a moda. Por que não olhar para moda sem preconceito? Por que não examiná-la como qualquer outra indústria, como a dos filmes, por exemplo? ${ }^{18}$
\end{abstract}

Na década de 90, já sem tanto reconhecimento da crítica, lançou Até o Fim do Mundo (Bis ans Ende der Welt, 1991), O Céu de Lisboa (Lisbon Story,1995), Além das Nuvens (Al di là delle nuvole,1995), em parceria com Michelangelo Antonioni, e Buena Vista Social Club (1999), documentário sobre a música cubana.

Em 2002, Wenders dirigiu Twelve Miles to Trona que foi a continuação do projeto do produtor Nicholas McClintok chamado Ten Minutes Older. Filmaram uma reflexão sobre o tema do tempo na virada do Milênio. Em apenas dez minutos, quinze diretores consagrados foram convidados a criarem a sua própria visão sobre o significado do tempo. Victor Erice, Aki Kaurismaki, Werner Herzog, Chem Kaige, Spike Lee e Jim Jarmush, entre outros, foram companheiros de direção nesse projeto.

$\mathrm{Na}$ Alemanha, filmou um documentário sobre música chamado "Ode to Cologne" (2002), com os seus amigos do BAP. O grupo BAP, nome originário da palavra Bapp, que significa pai no dialeto de Colônia, começou a despontar no cenário musical em 1979, com o lançamento do primeiro LP. No começo, a banda de seis integrantes se apresentava em festinhas de escolas e bairros e em eventos promovidos pela iniciativa privada. Depois, alcançaram fama suficiente para bancar seus próprios shows. O curiosos sobre essa banda de rock'n roll de Colônia que cantava em um certo dialeto que necessita de legendas para todo o resto da Alemanha.

No ano de 2003, ele dirigiu Soul of a man, contribuiu com a segunda parte de uma série em formato de documentário intitulada The Blues que teve, inicialmente,

\footnotetext{
18 Informação extraída e traduzida pela autora do site oficial do cineasta: http://www.wimwenders.com/movies/movies_spec/notebookoncitiesandclothes/notebookoncitiesandclothes.htm, Acessado em 8/7/2014.
} 
Martin Scorsese como produtor executivo. O filme explorou a carreira musical dos músicos de blues Skip James, Blind Willie Johnson e J. B. Lenoir.

Em 2006, passou um tempo no Congo contribuindo com um projeto dos Médicos Sem Fronteiras. Produzido pelo ator espanhol Javier Bardem e dirigido por cineastas de vários países, o filme celebra os 20 anos da organização Médicos Sem Fronteiras e em seus cinco segmentos aborda os diferentes males que atingem crianças e jovens da África e da América Latina. Cada parte pode ser vista como um curtametragem independente, com tema e linguagem específicos. Em "Invisíveis", por exemplo, o alemão Wim Wenders trata das adolescentes estupradas em massa durante a guerra civil no Congo. É talvez o segmento menos programático e mais inventivo do documentário. Esse episódio, inclusive, foi premiado no Berlinale de 2007.

Pina, em 2011, foi um trabalho que instigou quem o viu. É uma espécie de “filme ensaio". Certamente, tributário de Chris Marker (La Jetée - 1962), que foi o primeiro cineasta a fazer um filme nesse formato ao misturar a linguagem do documentário com reflexões pessoais. Wenders também teve a intenção de fazer um filme reflexivo, no entanto queria filmá-lo em 3D. Até então, filmes em 3D eram associados aos filmes de aventura ou ação. Essa ferramenta rara dentro dos documentários fez com que Wenders inovasse ao utilizar a tecnologia para ressaltar a sua amizade, admiração, respeito e proximidade com a coreógrafa alemã Pina Bausch. Enquanto a terceira dimensão costuma ser usada para se obter um efeito maior de imersão, o filme optou por aumentar a noção de espaço - fundamental à dança. Ao invés de limitar-se ao palco, levou os bailarinos de Pina para às ruas, galpões enormes e usinas desativadas. O filme teve uma excelente repercussão da crítica. Bailarinos, música, figurino, cenário, escassez de diálogos e toda a força dos gestos em sintonia com a dança, saltaram à tela sob a forma de mais uma possibilidade de cinema.

Em 2012, Wenders trabalhou em solo brasileiro. ${ }^{19}$ Em agosto, iniciou, no Espírito Santo, as filmagens do documentário $O$ sal da terra sobre a trajetória do fotógrafo mineiro Sebastião Salgado. A idéia era que o filme ficasse pronto junto com o lançamento do livro "Gênesis" (2013), de Salgado e a abertura da exposição fotográfica

\footnotetext{
${ }^{19}$ Informação extraída do portal G1: http://g1.globo.com/espirito-santo/noticia/2012/08/wim-wendersgrava-filme-com-sebastiao-salgado-no-es.html, Acessado em 15/03/2013.
} 
itinerante que se iniciou no Museu de História Natural de Londres. No entanto, o filme foi lançado, oficialmente, apenas em 2014.

Toda a filmografia de Wim Wenders, no seu entendimento, se resume em quadros da sua cabeça. Tudo aquilo que ele decidiu filmar, já havia visto, refletido ou sentido e precisava, de alguma maneira, exteriorizá-lo. Na maneira de perceber a sua trajetória, ele sintetiza

Dos quase 30 filmes que fiz, só vão restar os que foram feitos com convicção e amor, todos os outros não vão permanecer. Os que vão permanecer, de certa forma, refletem uma forma de ver o mundo, isto permanece.

Fizemos essa pequena retrospectiva da trajetória de Wim Wenders para entendermos que todo o processo de construção de uma ideologia fílmica não se dá ao acaso. Um filme, muitas vezes, é a soma das vivências de quem o fez. É o resultado de todo um arcabouço teórico, imagético e sensorial construído ao longo dos anos. $\mathrm{Na}$ poesia das imagens dos seus filmes, Wenders deixa as marcas da sua história. Uma história que começa com o nascimento em uma Alemanha fria e acinzentada destruída no pós-guerra e continua numa casa, na companhia de um irmão, uma mãe doente e um pai recluso. A falta de diálogo e a incomunicabilidade não poderiam estar ausentes na futura narrativa dos seus filmes. Esse alemão que se encantou pela cultura pop americana, aventurou-se pelas estradas, mas sofreu as conseqüências de ser um estrangeiro dele mesmo. Sua identidade ficou no aeroporto e outras buscas e questionamentos surgiram ao longo do caminho.

Os estudos de filosofia serviram como uma bússola para orientá-lo na ontogênese do cinema. O que buscam as suas personagens? Quais são os seus anseios? Por que essas imagens são tão significativas em nossas histórias? Será possível viver em um mundo tão complicado? Algumas dessas respostas foram extraídas sob a forma de cinema. Muitas das suas histórias falam sobre as relações entre as pessoas, a eterna busca por uma identidade, a viagem como uma possibilidade de auto-conhecimento ou mesmo uma metáfora da travessia pela vida. Por intermédio das imagens, Wenders percorreu uma cultura em ebulição. Documentou o rock, o blues, a moda e alguns dos seus ídolos do cinema como o grande mestre japonês Yasujiro Ozu. Aprendeu como ele, inclusive, que a câmera quanto mais próxima, mais cúmplice de quem a observa. A 
calma em observar ao máximo e o respeito aos costumes, aos ritos e a temporalidade, suspeitamos que também originou-se daí.

A fotografia também é uma evolução para o cinema. Wim Wenders, na sua juventude, foi um pintor que se descobriu fotógrafo. No silêncio da captura e na instantaneidade da latência das imagens, percebeu que por ali poderia começar a criar narrativas, a possibilidade de contar uma história. Assim o fez nas suas andanças pelo mundo à procura de locação para um filme ou mesmo para retratar algum lugar vazio, mas cheio de significados. O cinema apareceu na sua vida como uma linguagem complementar. Tudo aquilo que teve vontade de dizer, de alguma forma, deixou impresso na película. O gênero escolhido por ele complementa a sua identidade. Nos road movies as personagens seguem pela estrada sempre em busca de algo. A gênese veio da literatura, mas para Wenders foi no cinema que ele se completou. $\mathrm{O}$ filme Alice nas Cidades, para ele, foi o começo de tudo: um gênero de cinema e de uma fotografia que questiona a imagem e precisa se expressar. 


\section{Da literatura de viagem aos road movies}

Desde cedo, já nos deparamos com uma imaginação fértil e um desejo de independência narrado nas fábulas infantis: "pela estrada afora eu vou bem sozinha...". Pegar a estrada, ir rumo ao inesperado, ao desconhecido, é um desejo que nos acompanha.

Os teóricos da literatura perceberam isso e criaram o conceito que já mencionamos anteriormente chamado de romance de formação (Bildungsroman). $\mathrm{O}$ romance de Johann Wolfgang Goethe, Os anos de aprendizado de Wilhelm Meister (Wilhelm Meisters Lehrjahre, 1795-1796), é um dos prenúncios desse gênero cujo "conteúdo é a educação dos homens pra a compreensão prática da realidade" (LUKÁCS, p. 592, 2006). Foi ele que cunhou a fórmula paradigmática que mostra a vida, os hábitos e costumes do povo alemão. Wim Wenders, inclusive, se inspirou nesse livro para filmar o roteiro do Peter Handke. Ele, ${ }^{20}$ por iniciativa própria, escreveu um roteiro sozinho, sem passar por uma escrita literária prévia, e escolheu mudar a "cronotipa" da obra e passar o enredo do século XII ao seu momento contemporâneo, ou seja, os anos de 1970. A seu modo, transmitiu uma roupagem moderna ao filme. Por ora, o personagem escapa daquilo que foi narrado por Goethe. Wilhelm não quer ser um ator ou um homem de teatro, seu maior desejo é se transformar em um escritor peculiar.

A literatura de viagem é um gênero literário que consiste geralmente em uma narrativa acerca das experiências, descoberrtas e reflexões de um viajante durante o seu percurso. Narrativas como Odisséia, de Homero, datadas da Antiguidade Clássica ou Viagens de Marco Pólo, em plena Idade Média, trazem consigo o olhar de jornadas que despertam a curiosidade de quem acompanha as aventuras por eles contadas. Uma perspectiva um pouco mais factual - mas não menos criativa - são as cartas de Pero Vaz de Caminha e Américo Vespúcio e a descoberta das Américas. ${ }^{21}$

\footnotetext{
20 Informação extraída do texto Peter Hanke (n. 1942), escrito por Pablo Gonçalo em http://revistamododeusar.blogspot.com.br/2013/06/peter-handke-cinema-e-poesia-por-pablo.html

${ }^{21}$ Informação extraída do site http://www.livrosepessoas.com/2011/07/29/o-que-e-literatura-de-viagem/
} 
A Renascença, também conhecida como Era dos Descobrimentos, criou um cenário favorável para a Europa em meio às artes e às ciências em pleno século XVI. O texto fundamental da chamada travel writing é de Richard Hackluyt (1552-1616) Voyages (1589), em que relata as descobertas realizadas pela Inglaterra em pleno momento de expansão marítima.

Com o passar dos séculos, o gênero literário cria novos adeptos. Os impérios se expandem (principalmente Inglaterra e França) e chegamos ao século XIX com viajantes que aliam a literatura à ciência, incluindo o estudo de novas paisagens com a fauna e a flora consideradas "exóticas", revelando nas entrelinhas o pensamento eurocêntrico dominante.

No século XX, toda a vivência antropológica apoiada na cartografia e no espírito investigativo dos autores que se desenvolveu com o passar dos anos fez com que a literatura de viagem encontrasse o seu apogeu nas décadas de 70 e 80 sobrepujando o romance, uma vez que se utilizava de personagens e de um ritmo da narrativa, muitas vezes, baseado em fatos reais. Por meio dela, o exterior chama, mas o exterior só chama porque o interior escuta. Existe, de fato, uma ambiguidade entre a ficção e "a realidade". O viajante-narrador se encontra nessa poética do devaneio. Ser é estar. Se ele está aqui, é porque ele é. Assim como James Joyce, ele olha por dentro e vê. Baudelaire também dizia que o homem é um ser vasto porque tem o mundo dentro de si. Só por esses aforismos, percebemos o quanto essa literatura nos instiga.

Desde então, a literatura de viagem delimita seu espaço dentro dos gêneros textuais atraindo um público de perfis variados, despertando o interesse na leitura de relatos de terras longínquas, com os seus embates, desafios e imprevisibilidades. $\mathrm{O}$ cineasta alemão Wim Wenders desde pequeno foi atraído por esse tipo de literatura. A Odisséia, de Homero, e os textos de Goethe instigaram o seu olhar. ${ }^{22}$ As narrativas de viagem remontam às jornadas ancestrais da humanidade, às raízes nômades. As pinturas milenares de Lascaux (França) ou Altamira (Espanha), por exemplo, já seriam registros representativos dessa paisagem. Paisagem cheia de vazios e vestígios de uma humanidade que os personagens de Wenders insistem em contemplar.

\footnotetext{
22 O cineasta conta um pouco dessa influência no documentário produzido pelo Goethe Institut (2007) Àquele que saiu a procura. Os primeiros anos de Wim Wenders.
} 
No cinema (STRECKER, 2010, p. 251), os primeiros road movies traduziam a descoberta de novos territórios ou a expansão das fronteiras. Rastros de Ódio (The Seachers, 1956) clássico de John Ford estrelado por John Wayne, já representava um país que criava a sua identidade a partir da expansão em direção ao oeste, após a Guerra Civil. Nesse western podíamos perceber a representação de uma identidade em construção; já em outros filmes mais recentes, vemos a representação de identidades em transformação. No caso, esses filmes exploram as paisagens sociais mas, acima de tudo, os seus personagens buscam uma liberdade pessoal. É o caso, por exemplo, de Curva do Destino (Detour, 1945), clássico filme noir do diretor americano de origem austríaca Edgard G. Ulmer, antigo assistente de Murnau. Já Sem Destino (Easy Rider, 1969), de Dennis Hopper, seria a perda da inocência durante o período do Vietnã.

A estrada é um tema permanente na cultura Americana. Ela define o espaço entre a cidade e o campo. É um vazio expandido, a tabula rasa, a última fronteira verdadeira (DARGIS apud STRECKER, 2010, p.1). Nos anos 40, a estrada serviu prontamente aos filmes como uma espécie de rota simbólica para traçar uma identidade nacional unificada frente ao regional, racial, étnico e às diferenças de classe que a guerra tornou aparente, e, mais potencializada, por mostrar como a cultura popular deu aos Estados Unidos a sua coerência de "América", a casa de todos (COHAN e HARK, 1997, p. 114).

Na campanha publicitária do filme Easy Rider, em 1969, estava exclamado em letras garrafais: "Um homem saiu a procura da América e a podia ter achado em qualquer lugar", e isso nos lembra um sentimento condensado que pode ser associado ao projeto ideológico de um road movie, certos esquecimentos que a narrativa de viagem, especificamente, reconta. O road movie é, nesse sentido, como o musical e o western, um gênero de Hollywood que captura a peculiaridade dos sonhos americanos, as tensões e ansiedades, mesmo quando são importados pela indústria cinematográfica de outras nações. Ao longo das leituras do The Road Movie Book ${ }^{23}$ percorremos toda a trajetória e a estrutura dos road movies, e, por fim, destacamos e a resumimos em quatro particularidades:

23 COHAN, Steven e HARK, Ina. The road movie book. Routledge: Londres, 1997. 
1) A narrativa da estrada responde a uma quebra da unidade familiar, "aquela edípica peça central da narrativa clássica", e então testemunha a conseqüência da desestabilização da subjetividade do homem e empoderamento masculino;

2) Os acontecimentos se dão ao redor das personagens: o mundo histórico é sempre muito mais do que um contexto, e os objetivos ao longo da estrada são geralmente ameaçadores e fisicamente agressivos;

3) O protagonista da estrada se identifica com os significados de um transporte mecanizado, o carro ou a motocicleta, que se tornam a única promessa pessoal em uma cultura de reprodução mecânica;

4) Trata-se de um gênero tradicionalmente focado, quase exclusivamente, nos homens e na ausência de mulheres. A estrada promove ao homem uma fantasia escapista ligando masculinidade à tecnologia e a definindo como um espaço de resistência ao que contempla às responsabilidades domésticas: vida do lar, casamento e emprego.

Para Strecker (2010, p. 25), o gênero "road movie" tem muito a ver com um mergulho no desconhecido, com a jornada de descoberta; e é parente da literatura de aventura. Em certa medida, uma expressão contemporânea do romance de formação.

Assim como nas comédias de Frank Capra, o romance e o reestabelecimento de um consenso democrático dominou a estrada nos filmes de Hollywood nas décadas de 30 e 40, conforme visto nos filmes: Fugitive Lovers (1934), Sullivan's Travels (1941), Saboteur (1942) e Without Reservations (1946). Quando Jean Baudrillard comparou a moderna cultura americana com "espaço, velocidade, cinema e tecnologia" ele poderia facilmente acrescentar que o road movie é um emblema máximo dessa cultura. A estrada sempre foi um tema persistente na cultura americana. O seu significado está relacionado com a mitologia popular e a história social, retoma a fronteira nacional do ethos, mas foi transformado pela interseção entre a indústria do cinema e a indústria automobilística do século XX ( COHAN e HARK, 1997, p. 1). A partir dali, a narrativa dos filmes é conduzida estrada afora pelo percurso dos seus personagens motorizados. Pressupõe-se que uma mudança crucial de paradigma no gênero ocorreu nas décadas seguintes à Segunda Guerra Mundial, quando a estrada e o filme de estrada foram 
ambos mediados pela publicação do On the Road, em 1957, pelo Jack Kerouac. Estar na estrada, não importa se chegando ou partindo, define uma experiência do pós-guerra americano. É por isso que eles chamam as estradas de freeways. Por esse caminho significa que você pode ser livre na América.

De acordo com Corrigan (apud COHAN e HARK, 1997, p. 2), o road movie é muito mais do que um fenômeno do pós-guerra. Algumas revoluções sociais ajudaram a definir esse período (1969) na América, incluindo a liberação feminina, direitos civis e outros movimentos da juventude, além do aumento gradual do envolvimento dos americanos na Guerra do Vietnã.

As aventuras do personagem Sal Paradise, mais do que nunca, assemelhava-se com aqueles filmes de estrada pré década de 50, onde a imprevisibilidade e sorte que surgiam na estrada significavam que chegar até um destino dependiam da gentileza e dos veículos motorizados de outros; por exemplo, como as caronas e viagens de ônibus.

Na redefinição do protagonista da estrada como um marginal e um inassimilado pela cultura convencional, o romance de Kerouac reconfigurou, significativamente, a "personalidade"da estrada. Antes do On the Road, os protagonistas dos filmes de estrada eram casais heterossexuais (It Happened One Night (1934), You Only Live Once (1937), Sullivan's Travels (1941), They Live by Night (1948) e The Long, Long Trailer 1953) ou comunidades com pessoas deslocadas (Wild Boys of the Road - 1933, The Grapes of Wrath - 1939 ou Three Faces West - 1940).

Embora a estrada sempre tenha funcionado no cinema como um espaço alternativo onde $\mathrm{o}$ isolamento do mainstream permite várias experiências transformadoras, a grande maioria dos filmes de estrada feitos antes dos anos 60 preferiram imaginar uma reintegração final dos viajantes na cultura dominante. Alguns errantes perpétuos de 1930, sendo o mais famoso Tom Joad (Henry Fonda) de Vinhas da Ira, podem emergir no gênero, e outros desafiadores da lei podem perecer nas leis da sociedade que não perdoa, como no casal fora da lei (Fonda e Sylvia Sidney) em Só se vive uma vez, mas esses casos são exceção. Mais paradigmático do clássico filme de estrada é Aconteceu uma noite, o grande ganhador do Oscar de 1934. Sua protagonista Ellie Andrews (Claudette Colbert) foge da opressão de sua origem rica e busca a sua 
libertação na normalidade das pessoas que encontra pela estrada, mais notavelmente no seu inesperado companheiro, o jornalista Peter Warne (Clark Gable).

Os casais são uma configuração dominante nos filmes de estrada, assim como nos filmes de Hollywood em geral. O filme de estrada confia em um casal por razões práticas do próprio contar da história. Duas pessoas em um banco da frente de um carro são perfeitas para um fácil enquadramento clássico, além de deixarem o diálogo fluir. No confinamento do espaço do carro, a acomodação compartilhada, o almoço na cabine, além dos possíveis sofrimentos e desesperos que criam uma intimidade e fazem o argumento do conflito surgir rapidamente.

Normalmente, os filmes mais interessantes desse gênero são justamente aqueles em que a crise de identidade do protagonista da história reflete a crise de identidade de uma cultura, de um país. A chave ficional serve também de metáfora para uma sociedade à procura de uma identidade própria. O filme Easy Rider (1969), por exemplo, é um marco dessa filmografia da contracultura. Peter Fonda e Dennis Hopper viajam de moto pelo sul e sudoeste dos Estados Unidos com o objetivo de desvendar um país e, ao mesmo tempo, em busca das suas liberdades pessoais.

O cineasta Walter Salles (STRECKER, 2010, p. 252) acredita que nesses filmes o que é sentido é sempre mais importante. Silêncios são valiosos, ao contrário dos filmes comerciais, onde ações são criadas a cada três minutos para atrair a atenção do espectador. Ainda de acordo com Salles, o road movie deve obedecer apenas uma regra: acompanhar as transformações dos personagens em confronto com a realidade. No caso, a câmera deve acompanhá-los com leveza, à maneira dos documentários. Muitas vezes, os limites entre a ficção e a realidade acabam sendo rompidos, com o objetivo de se contar uma história. Para ele, não há mais verdade objetiva, mas a verdade da observação. Não há mais o exterior (o mundo) e o interior (sua representação imaginária), mas apenas o filme, que é a síntese do mundo e da imaginação do cineasta.

Walter Salles ainda nos conta um dos seus mais importantes aprendizados quando assistiu a Alice nas Cidades e No Decurso do Tempo: em cinema o que é invisível é mais importante do que é visível. O que se sente é mais importante do que aquilo que se verbaliza (STRECKER, 2010, p. 252). Nesses dois filmes de palavras 
contidas e gestos minimalistas, as sensações transbordam pela trocas de olhares entre as personagens, pelo monólogo interior que, às vezes, invade o som diegético do enquadramento, além da própria composição da fotografia repleta de vazios que, propositalmente, deixa os espaços livres para o espectador sentir e, ao mesmo tempo, pensar. Tudo isso será analisado, um pouco adiante, quando adentrarmos na significação de cada um dos filmes.

Wim Wenders foi um dos grandes renovadores da linguagem cinematográfica nos anos 80. Levou a experiência formal dos Cinemas Novos dos anos 60 um passo adiante, para a paisagem americana, a partir dos anos 70. Apaixonado pelo cinema clássico dos Estados Unidos, em especial pelo western e pelo filme noir dos anos $40 \mathrm{e}$ 50. É interessante observarmos que nos filmes do gênero western a idéia de viagem é uma constante. Os vaqueiros atravessam longas extensões de território com o gado; as diligências cortam as estradas ermas, parando em algumas parcas estalagens, além das caravanas que percorrem as planícies inóspitas. Já os filmes noir tiveram a sua estética muito influenciada pelo Expressionismo alemão. A iluminação demarcada com pontos claros e escuros (sombras), além do ponto de vista subjetivo e psicológico das personagens são características bem pungentes nesses filmes. Wenders, ao seu modo, reinventou, conceitualmente, os filmes de estrada. O filme Alice nas Cidades foi a sua primeira incursão no gênero.

\section{1. - Alice nas Cidades - A fotografia como representação de espaços em trânsito}

\footnotetext{
"Encontrei com Alice nas Cidades a minha própria caligrafia no cinema. Muito mais tarde, tornou-se claro que, nestes anos que passaram, o meu trabalho oscilara entre dois pólos: os filmes em preto e branco sobre temas pessoais e os filmes a cores, adaptações de obras literárias."
}

(A lógica das imagens - Wim Wenders)

Neste capítulo, mostraremos a relevância do espaço no filme Alice nas Cidades. Lugares e não lugares, conforme definiu o antropólogo Marc Augé nos contam histórias e dizem muito sobre nós mesmos. Pretendemos comprovar isso, no filme, ao mostrarmos os lugares percorridos pelos personagens, e pelas próprias idiossincrasias do cineasta ao filmá-los. Todos esses lugares transitórios instigam o nosso olhar e denotam, ao mesmo tempo, a identidade cultural de um país, além da estética de um gênero cinematográfico. Nesses lugares repletos de sons, silêncios, ruídos e vestígios, uma história, aparentemente, singela começa a ser narrada. Somada aos diálogos 
lacônicos dos personagens, a paisagem, mesmo vazia, transborda significados e ajuda a completar os sentidos implícitos na fala deles. A fotografia também é de grande relevância no filme. Ela revela e fixa os deslocamentos, os lugares de passagem dos personagens e a relação entre eles. Veremos que toda essa transitoriedade entre as imagens fixas (fotografias) prenunciam o desejo pelas imagens em movimento (o cinema).

Narrar quer sempre dizer que as imagens são forçadas a alguma coisa. É assim que WW problematiza o início dos seus filmes que se dividem, geralmente, nestes dois grupos: no grupo (A) são todos filmes em preto e branco, exceto Nick's Film, que, segundo Wenders, não pertence a nenhum desses grupos. No outro grupo (B), são todos filmes a cores que se baseiam em romances já existentes. Todos os filmes do grupo (A) se baseiam numa idéia dele, abrangem sonhos, sonhos acordados e vivências. Esses filmes têm uma estrutura flexível, enquanto os filmes do grupo (B) têm uma estrutura narrativa muito fechada. Normalmente, o tema dos filmes do grupo (A) foram descobertos e perscrutados somente nas filmagens. O tema do grupo (B) já era previamente conhecido, ele só precisaria descobrir o que funcionaria ou não nele. Em suma, o que o cineasta quer dizer é que os filmes (A) foram realizados de dentro para fora e inversamente os filmes (B).

Antes de filmar Alice nas Cidades (1974), Wenders estava prestes a largar o cinema. O seu último filme A Letra Escarlate (1973) tinha sido uma verdadeira decepção. Ele investiu tudo nas filmagens de Alice nas Cidades. O seu desejo era provar que podia contar histórias como mais ninguém.

Seu primeiro longa-metragem profissional foi $O$ Medo do Goleiro Diante do Pênalti (Die Angst des Tormanns Beim Elfmetter, 1971). O filme se baseia em uma novela do escritor Peter Handke, grande amigo do diretor, que colaborou, mais adiante, nos filmes Movimento em Falso (Falsche Bewegung, 1975) e Asas do Desejo (Der Himmel über Berlin, 1988). O próprio Peter Handke disse, ao ser entrevistado em um documentário sobre a obra de Wim Wenders, que ao assistir um dos seus primeiros curtas-metragens chamado Alabama (1969) ficou impressionado ao ver como ele se liberava da narrativa. Nessa época, todos queriam se liberar de estórias, do plot, das 
referências de Hollywood. Era natural. Para Handke e todos que assistiram a esse filme, era um alívio que nada tinha obrigação de acontecer.

Em Alice, Wim Wenders deu início a sua trilogia de road movies (filmes de estrada). $\mathrm{O}$ filme é baseado nas primeiras viagens de Wenders às Américas, além de ser muito influenciado pela cultura americana e toda a força simbólica que a estrada (freeway-caminho livre) tem nela. É uma espécie de tentativa desse cineasta alemão de se sentir pertencendo a um mundo americano. Ao menos, contar uma história daquilo que viu, sentiu e experimentou. Normalmente, as histórias de Wenders começam sempre com lugares, cidades, paisagens ou ruas. Um mapa também pode ser um bom argumento para ele.

A sinopse do filme se desenvolve da seguinte forma: Um jornalista alemão chamado Phil Winter (Rüdiger Vogler) está com um tremendo bloqueio para escrever um artigo sobre os Estados Unidos e sem muito êxito, ele decide retornar à Alemanha. No balcão da companhia aérea, ele conhece uma mulher alemã e sua filha Alice (Yella Rottländer), de nove anos. A partir daí, inicia um confronto entre um personagem adulto, um jornalista que, forçosamente, vira um fotógrafo errante ao descobrir a paisagem dos Estados Unidos, e uma criança, Alice, menina que foi deixada pela mãe e está em busca de seus parentes, do seu passado. No entanto, a única coisa que ela possui é uma fotografia da casa da avó. A falta de raízes e a crise de identidade são os fios que vão compor o tecido virtuoso de um novo recomeço.

Todo filmado em preto e branco e em $16 \mathrm{~mm}$, Alice nas Cidades foi considerado por muitos como um dos melhores filmes de Wim Wenders. Um filme inspirado pelo existencialismo, que nos mostrou que viver é ficar se equilibrando, o tempo todo, entre escolhas e consequências, pela Nouvelle Vague (movimento do cinema francês) e o que esse gênero proclamou como um "cinema de autor", contestatório por excelência, com um cenário naturalista, cheio de poesia, lirismo e filosofia. A partir desse foco, percebemos que o preto e branco do filme é mais do que um recurso estilístico. $\mathrm{O}$ cineasta quer impor o seu modo de ver, a sua visão do que vê. Para Wenders, com a cor, 
ele pode desaparecer muito mais como fotógrafo. Ele não pode se tornar invisível, (ninguém nunca pode) mas ele pode deixar as coisas como elas são. ${ }^{24}$

Podemos dizer que a grande personagem do filme é a estrada entremeada pela paisagem urbana e a forma como ela se apresenta ao olhar, e como e até que ponto ela se materializa em imagem. Todo deslocamento, a viagem, na verdade, ganha contornos de transformação. Trata-se de uma busca: busca das suas raízes, das identidades, por imagens que se desdobram em uma história. Na busca para achar um lugar que conte uma história, o cineasta nos diz que

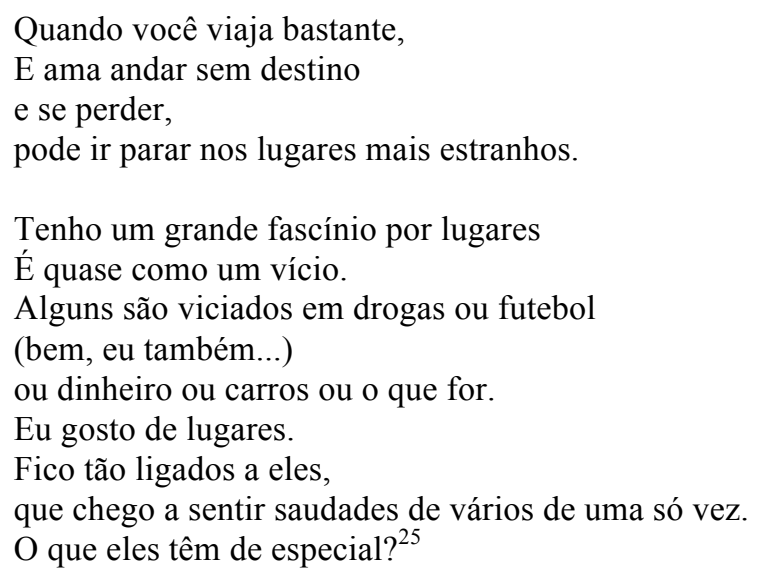

No filme, o lugar conduz o olhar do espectador para os planos que o diretor quer enfatizar. Os passeios que a câmera do diretor faz, ao longo da estrada, descortinam paisagens e pensamentos de um fotógrafo errante. A palavra foi substituída pela imagem, o gesto pela instantaneidade da fotografia de uma câmera Polaroid.

$\mathrm{O}$ ato de fotografar me mostrou algo novo. De repente fui capaz de olhar para as coisas, especialmente os lugares, de maneira completamente diferente e, de alguma forma, com muito mais precisão. Eu percebi que poderia usar a câmera como um dispositivo de gravação para captar mais do que uma imagem - algo como uma história que foi contada por cada lugar. ${ }^{26}$

No trecho acima, parece que Wenders nos conta, sem querer, o porvir da história do seu filme. Todos os seus filmes ocupam-se de pessoas que, em viagens, são expostas

\footnotetext{
24 Entrevista de Wim Wenders na Foam International Photography Magazine - \#31 ref. - Summer 2012. páginas $13-18$.

25 Trecho extraído do livro de fotografias editado por Wim Wenders: Lugares, estranhos e quietos. Tradução de Edson Lemos. São Paulo: Imprensa Oficial do Estado de São Paulo: Mostra Internacional de Cinema de São Paulo, 2010.

${ }^{26}$ Entrevista de Wim Wenders na Foam International Photography Magazine - \#31 ref. - Summer 2012. Pág.13 -17.
} 
a situações desconhecidas. Um fotógrafo em viagem pode estar em busca de imagens e, de maneira específica, de imagens que o ajude a contar histórias, a buscar respostas para um modo de ver, de dizer coisas, procurar sentidos, no fundo, para tentar se relacionar. O foco dos seus filmes é a visão e a percepção, além das pessoas que vêem as coisas de um modo diferente, de um modo mais poético, mais sensível, que percebem a sutileza de um mundo cada vez menos sutil, repleto de diálogos secos, entrecortados e gestos bruscos, mas que, no fundo, esses personagens de Wim Wenders sabem, conforme apontou Luhmann (1991, p. 11), que o amor também é um meio de comunicação simbólica.

Em Alice nas Cidades, o começo de tudo é um longo travelling que nos leva até a imagem do céu pontuado por um avião, e, em seguida, retorna para praia. A atmosfera sonora inicial do filme nos é dada por meio de um ruído, insuportável, do motor de um avião e, em seguida, pelos sons quase hipnóticos das ondas do mar. Há um corte sonoro para a guitarra arpejada dos $\mathrm{Can}^{27}$, já o horizonte forma uma linha que é rapidamente contrastada no corte do plano seguinte com o travelling vertical que nos apresenta o personagem Philip Winter debaixo de um pontão de madeira, o mesmo boardwalk sobre o qual ele cantará, depois de tirar mais uma fotografia das ondas do mar, a sua dura realidade com a Polaroid:

\section{Under the boardwalk \\ Down by the sea \\ On a blanket with my baby \\ That's where I want to be}

Essa é a letra de Under the boardwalk dos Drifters, ${ }^{28}$ grupo de doo-wop ${ }^{29}$ dos anos 50. Philip Winter está, de fato, debaixo de um pontão, junto ao mar, mas está bem longe do aconchego de dividir o cobertor com a sua amada. Na maior solidão, ele tira fotos polaróides do horizonte que, simplesmente, assim como a música, não mostram aquilo que ele vê.

\footnotetext{
${ }^{27}$ Banda alemã de rock experimental.

${ }^{28}$ Famoso grupo americano de doo-wop e rhythm and blues dos anos de 1950. É curioso observarmos que a tradução do termo drifter, em inglês, significa andarilho ou vagabundo.

29 Doo-wop é um estilo de música vocal baseado no rhythm and blues. Surgiu, inicialmente, na comunidade negra norte-americana, na década de 1940, e tornou-se popular nos Estados Unidos durante a década de 50 e 60. Significado extraído do link: http://pt.wikipedia.org/wiki/Doo-wop
} 


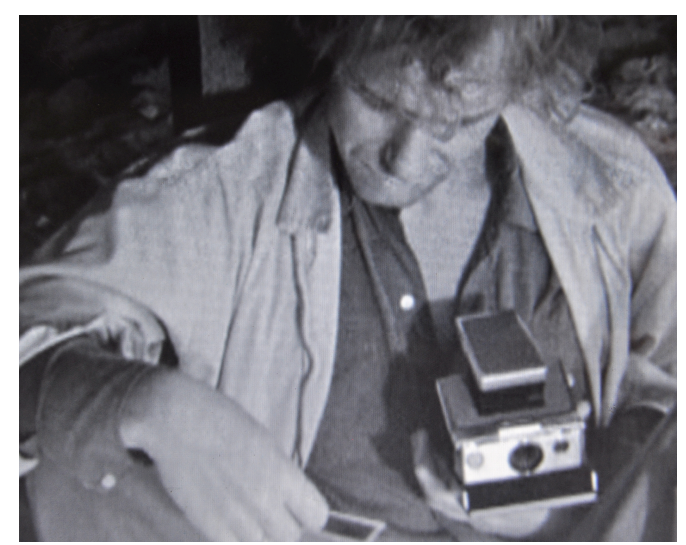

Figura 5 - Philip Winter observa a fotografia que tirou

Na poética de Wenders, a fotografia pontua todo o filme. Não apenas no encadeamento natural (sintagma) das fotos em movimento do cinema, mas também por meio das fotos instantâneas tiradas por Phil que são bastante representativas de um mundo diluído pelo imediato, por uma experiência vazia de mundo, que se revela e, rapidamente, se esvai. Assim como as paisagens, nada é perene, tudo é móvel, líquido e transitório. A verdade é sempre questionável. É interessante observarmos essa analogia de sentidos que o diretor faz através das imagens.

Até a segunda metade dos anos 70, a fotografia tinha um caráter predominantemente documental. No entanto, parece que Wenders questiona, ao longo do filme, esse percurso da fotografia, conforme conceituou Rouillé (2009), entre a fotografia-verdade (documental), uma espécie de espelhamento de um real e a fotografia-expressão (artística), poética por natureza, e repleta de sentidos, além do próprio nascimento de uma história (narrativa audiovisual) por meio da relação entre os atores Rüdiger Vogler (Philip Winter) e Yella Rottländer (Alice) que atuam de uma forma tão natural que fazem do filme uma espécie de documentário sobre a relação deles.

No próprio ato da direção de seu filme, Wenders se encontrava na busca de uma espécie de espelhamento de um real. De acordo com o depoimento do ator Rüdiger Vogler, ${ }^{30}$ ele estava sempre perto da câmera durante as filmagens. Wenders era a única pessoa que realmente via o que o ator tinha feito. Cada pequeno movimento ou mesmo

\footnotetext{
${ }^{30} \mathrm{O}$ ator faz esse depoimento na sua entrevista gravada no documentário intitulado Os primeiros anos de Wim Wenders.
} 
uma expressão facial, mesmo que fosse um pequeno movimento dos olhos ou da boca, ele sempre observava.

Wim Wenders usa a fotografia como se por meio dela pudesse lidar com a transitoriedade da vida, das imagens e do próprio cinema. Assim como o seu personagem Philip Winter, ele se encontra no filme como uma espécie de diretor entregue às imagens e a tudo aquilo que consegue captar delas. Os planos cinematográficos são repletos de silêncios entrecortados pelos ruídos das ruas e os monólogos interiores do Phil que, por vezes, são expressos na tela. É importante observarmos que esses silêncios, ruídos e monólogos duram quase dezoito minutos até o momento que ele cruza, literalmente, com a Alice numa porta-giratória do aeroporto.

Em algumas entrevistas, Wenders diz que escreve roteiros apenas para garantir o financiamento dos seus filmes. Aquilo que ele realmente filma é escrito no dia anterior. É essa a impressão que temos realmente. As imagens que conduzem o filme parecem com o seu diário de bordo ou bloco de notas. As fusões em preto (fade out) sucedem-se sem que nada de significativo aconteça, como supostas páginas em branco, com passagens de tempo indefinidas. O pintor Edward Hopper é citado, por diversas vezes, nos planos do filme. Vemos a imagem de um posto de gasolina que podia ser de um quadro feito por ele, caso o preto-e-branco não tivesse se imposto no filme. Wenders, aliás, sempre teve uma certa predileção pelas pinturas desse artista que soube representar muito bem as paisagens tipicamente americanas - mais do que paisagens, ele registrou lugares banais, do cotidiano das pessoas, como um posto de gasolina. $\mathrm{O}$ olhar pictórico de Hopper sobre as paisagens transmitem a experiência da "fronteira", o deslocamento em paisagens atravessadas pelos símbolos da civilização representados por imagens de estradas, postos de gasolinas, teatros, quartos de hotéis, faróis etc.

Nessa fotografia tirada por Phil, surge um garoto negro encostado à bicicleta, na frente de um posto de gasolina, que pergunta "Por que é que você está fotografando? O patrão não vai gostar." Ele responde depois de ter contemplado a fotografia: "Por nada." 


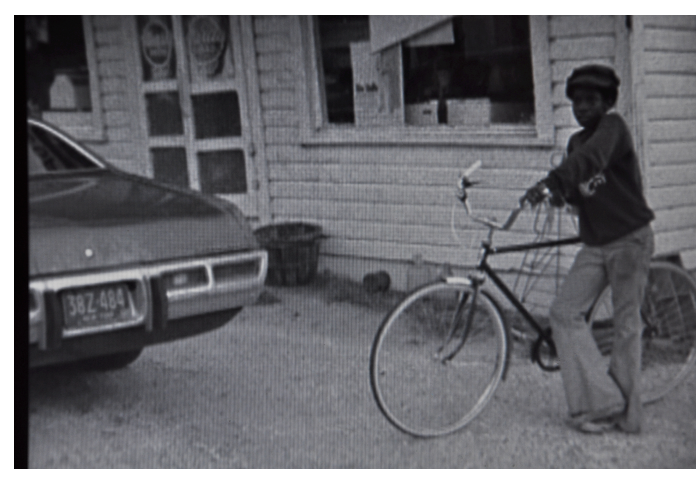

Figura 6 - O menino que fora fotografado no posto de gasolina

No carro, Phil confessará o seu desalento: as fotografias "nunca mostram aquilo que vimos." E de novo: "To shoot pictures: Jogando fora tudo aquilo que não suportamos."

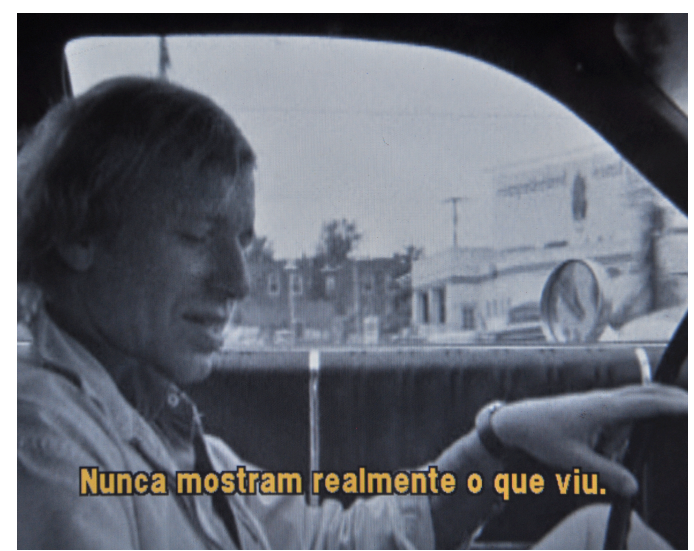

Figura 7 - Desalento de Phil ao observar a fotografia tirada por ele

De algum modo, parece que a queixa de Phil Winter ao negar "o real" da fotografia faz com que ele celebre, justamente, o cinema. A partir de tudo aquilo que a fotografia não consegue dizer, surge o cinema. Somente essa linguagem consegue caracterizar, discutir e avaliar a mobilização poderosa dos afetos, além da celebração dos valores e reconhecimentos ideológicos, fora toda consciência crítica que ela, de certo modo, impõe. É uma espécie de declaração do cineasta que se tornará clara mais tarde, quando Winter, também revoltado com a manipulação de imagens e palavras, destrói uma televisão com chutes e pontapés no quarto do motel Skyway.

Mais uma vez, a incomunicação se mostra de maneira gritante. De certo, o desejo dele é pôr abaixo a hegemonia alienante da televisão, na cultura americana, com todos os excessos de publicidade e programas banais, e de maneira irônica, fazer com que o espectador pense por meio do próprio discurso publicitário evocado na cena do filme que diz "que uma mente é uma coisa terrível para ser desperdiçada". Assim como 
a televisão mudou o cinema, a publicidade mudou a televisão; e hoje nos cabe, sem nenhuma dúvida, olhar as coisas de frente: o espírito publicitário se introduziu em quase todos os domínios da comunicação visual (Wenders). ${ }^{31}$ Na televisão, o enquadramento é mais fechado (close) para enfatizar o produto. Já nas paisagens urbanas, grandes outdoors publicitários disputam espaços junto aos carros e pedestres.

Essa crítica deixa bem claro as mudanças de rumo que as imagens tiveram: tornaram-se, cada vez mais, comerciais. É uma disputa freqüente entre a nossa atenção e entre cada imagem tentando superar a precedente. Em outras épocas, a missão mais nobre da imagem era se mostrar, hoje parece que o que ela mais quer é se vender.

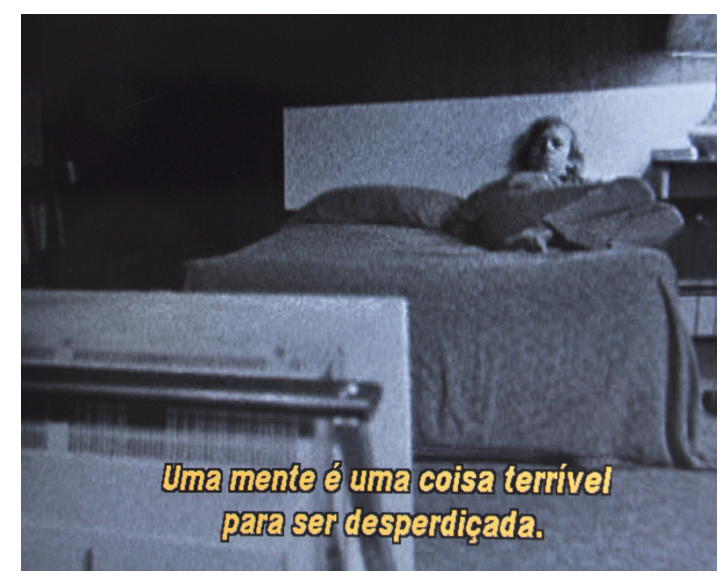

Figura 8 - Philip Winter assiste televisão no quarto do motel

É importante percebermos a alternância da densidade da construção dramática que o cineasta trabalha com o seu personagem. Em um determinado plano, dirigindo o carro pela estrada, ele desliga o rádio bruscamente "Falar consigo mesmo é mais ouvir do que falar" diz a personagem. É como se ela se fosse reinventando, construindo ao mesmo tempo o nosso universo metafórico: o das imagens.

E é assim que a imagem aparece nos filmes de Wenders. Esta conotação permite ao realizador organizar, minuciosamente, o filme: as fusões que remetem para as passagens de tempo, as horizontalidades dos travellings inevitáveis no carro, o uso da música e do som para estabelecer atmosferas e reações: o rádio, a televisão no motel (o berimbau que toca um can-can), a música dos Can que continua no seu arpejar melancólico, o órgão do estádio que Winter escuta ao longe. Todos estes elementos vão

\footnotetext{
${ }^{31}$ Wim Wenders. “A paisagem urbana”. Tradução de Maurício Santana Dias. Revista do IPHAN no 23/1994. Pág. 180.
} 
sendo delicadamente justapostos uns aos outros, apresentando Philip Winter na sua solidão à deriva, mas também o olhar com que Wenders atravessa os EUA.

É um olhar transitório, de passagem, documental, como comprova a sucessão de meios de transporte: carro, trem, avião, barco, bonde. Até as esteiras rolantes servem para confirmar a horizontalidade dos travellings do filme.

Philip Winter é enviado por uma revista alemã ao novo continente para escrever uma história sobre os Estados Unidos. Mas ao chegar na redação da revista, em Nova Iorque, ele aparece apenas com algumas fotos polaroid. Winter se justifica ao dizer que as histórias são sempre sobre coisas que se vê: imagens e signos. O editor, obviamente, quer uma história escrita em palavras, mas Phil só tem imagens. A importância dessas imagens é que somente elas conseguem narrar aqueles EUA que apenas ele vivenciou e, quem sabe um dia, vão ajudá-lo a compor a sua história. Ao seu modo, Wenders ressalta a fidelidade às imagens. No século XIX, o desenvolvimento das imagens deu um grande salto. A invenção da fotografia trouxe uma relação inteiramente nova entre a realidade e a sua representação, começou a existir "uma realidade de segunda mão".

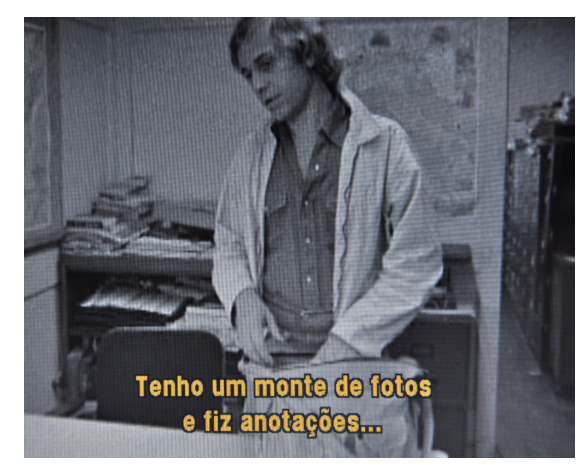

Figura 9 - Phil leva as fotos para o editor da revista

Também Wenders anda à procura de uma história. Isso se confirma quando ele ${ }^{32}$ diz que as histórias dão às pessoas a sensação de que há um sentido, de que por trás da confusão incrível de todos os fenômenos que as rodeiam se escondem uma ordem e uma última seqüência. As pessoas desejam esta ordem mais do que todo o resto; Wenders quase diria que a concepção de ordem e de história se relaciona com a concepção de Deus. As histórias são o substituto de Deus. Ou vice-versa.

\footnotetext{
${ }^{32}$ Wim Wenders. A lógica das imagens. Edições 70, Lisboa, 1990. Pág. 76
} 
Na busca por uma história, Phil ruma para o aeroporto. O encontro das duas personagens principais - Phil e Alice - se dá por meio de um belo recurso entre direção e fotografia: os dois se encontram em uma porta giratória do aeroporto. É como se a fotografia girasse para o cinema entrar. A partir dali, os dois destinos passam a ser um. $\mathrm{O}$ acaso entre a impossibilidade de embarque por causa de uma greve no aeroporto une os destinos da família de Alice e de Winter. A mãe da menina foge de uma relação amorosa fracassada. A partir de agora, Alice passa a ser o fio condutor da história de Winter. Antes de voltar para junto da família, ele tenta passar a noite com uma exnamorada alemã, com quem partilha a sua angústia:

(Winter): - Perdi o contato com o mundo;

(Ex- Namorada): - Sim, há muito tempo;

— Você não precisa cruzar a América por isso;

- Você se desconecta quando perde o seu sentido de identidade;

— Foi por isso que você veio para cá?;

- Para que alguém ouvisse as histórias que você conta a si próprio?

— A longo prazo isso não basta, meu querido.

Por fim, decide ir embora. Volta ao hotel e passa a noite com a mãe de Alice, quando ela diz para ele: “- Não quero dormir contigo, mas gostaria de dividir a cama contigo." Em pleno silêncio e solidão, parece que Wenders está tecendo um fio de uma trama poética, sensível e extremamente humana.

Quando acorda, Winter escreve no bloco de notas, enquanto olha a televisão. Em profundidade de campo, Alice dorme profundamente. Esse plano dá indícios da escrita de Phil. Será que ele está escrevendo sobre Alice? Será que, de fato, ele consegue começar a sua história? Na verdade, ele escreve uma série de desabafos sobre a televisão americana e a maneira como confirmam o status quo, mais uma crítica aos Estados Unidos e ao distanciamento das imagens frias da TV. 


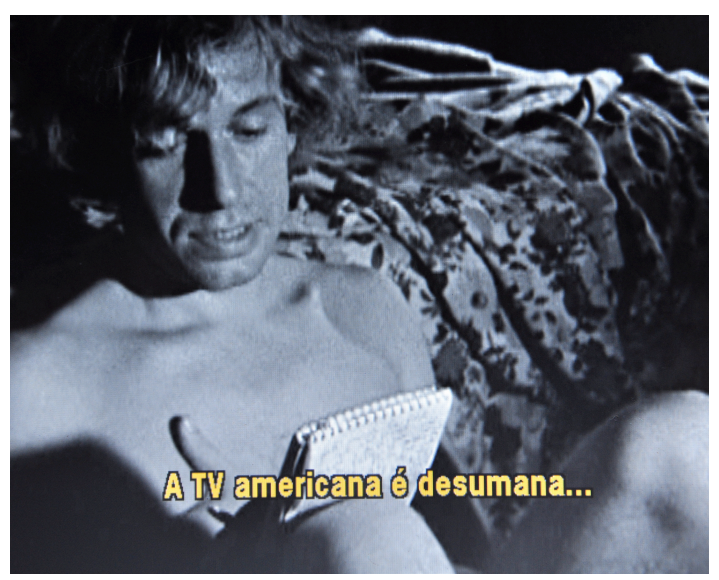

Figura 10 - Phil critica a televisão americana

Alice ainda não começou a transformá-lo. No outro dia, a mãe de Alice sai de casa sozinha. Deixa um bilhete marcando um encontro para mais tarde, mas ela não aparece. A partir daí, Alice também passa a ser uma pessoa perdida, assim como Winter. $\mathrm{O}$ encontro entre eles é o início de uma aventura, já a história é pela busca das identidades. No entanto, ao longo do filme, Wenders utiliza a fotografia ou a própria história das imagens para mostrar o quanto estamos perdidos: Phil, Alice, as pessoas que os rodeiam, os lugares, as paisagens e as imagens.

Em seguida, os dois pegam um avião para Amsterdã na tentativa de mais um encontro com a mãe de Alice. A partir dali, a transformação de Philip Winter começa a ser visível. A sua repulsa em relação à televisão é posta à prova justamente por Alice. Enquanto esperam pelo avião, a menina, com as suas próprias moedas, decide gastar dinheiro para ver televisão. Winter, simplesmente, olha para ela. Alice pede mais comida. Winter sai sem dizer nada. A televisão é o símbolo de uma inevitável e nova maneira de ver as coisas. Da maneira como essa janela for aberta, pode significar um "dar de cara" com o abismo do cinema.

O filme e a fotografia ganharam, de fato, um concorrente: a imagem eletrônica. No entanto, conforme salientou Wenders, ${ }^{33}$ a televisão instaurou, ao mesmo tempo, uma proximidade e uma distância. Sua imagens eram mais frias, menos emotivas que as do cinema; e além disso, ela nos afastou da idéia de que uma imagem pudesse possuir uma ligação direta com a "realidade". Não há mais "uma imagem única”, um negativo único, como no procedimento fotográfico.

${ }^{33}$ Wenders. A paisagem urbana. op.cit. pág. 181. 


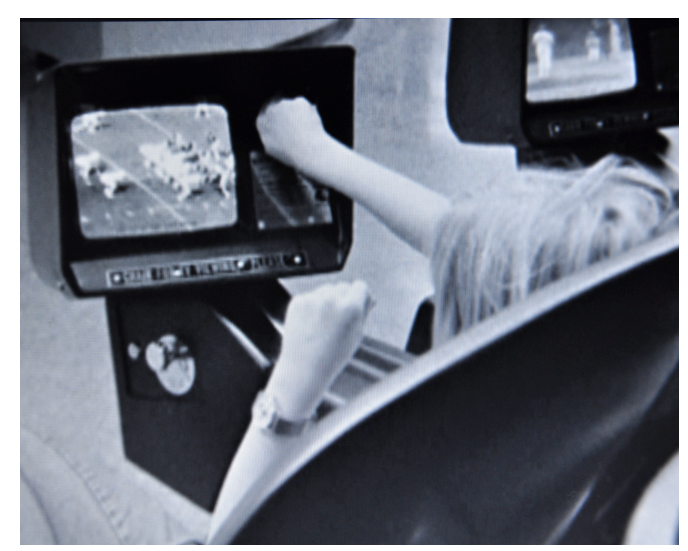

Figura 11 - Alice tenta assistir televisão no aeroporto

A ligação entre os dois vai crescendo, a tal ponto, que dividem a mesma escova de dentes no quarto de hotel. Alice, aos poucos, o vai tirando da sua angústia existencial. É a história de Alice que Winter vai construindo, ao mesmo tempo que constrói uma saída para a sua depressão. Quando a mãe de Alice falta ao encontro de Amsterdã, a crise se instala. Alice se desespera. É Winter quem a salva. Ele sugere que ela vá à procura da sua avó. A menina não sabe onde ela vive. Winter fala, ao acaso, dezenas de cidades alemãs. Alice é quase obrigada a escolher um destino com Winter. Veremos mais tarde que Wuppertal não foi uma escolha intencional, mas sim um modo de viajar para que eles descobrissem a Alemanha e, ao mesmo, a si próprios. No café da manhã, Alice descobre umas chaves na mochila de Winter: são do motel Skyway.

Quando vemos o insert do plano das chaves e o ouvimos dizer o nome percebemos como ele já está longe do sentimento dos EUA. No fundo, há um forte sentimento de vazio dentro deles. Por meio da imagem, Wenders reforça a densidade dessa poética metafórica do vazio. Este processo se iniciou na viagem de volta à Europa. No avião, Winter faz uma foto da janela. Ele entrega a foto para Alice que diz não ver nada ali. Em seguida, diz para ela esperar. Eis que surge a imagem em suas mãos. Alice faz uma cara de espanto e comenta: "É uma foto bonita. Tão vazia." 


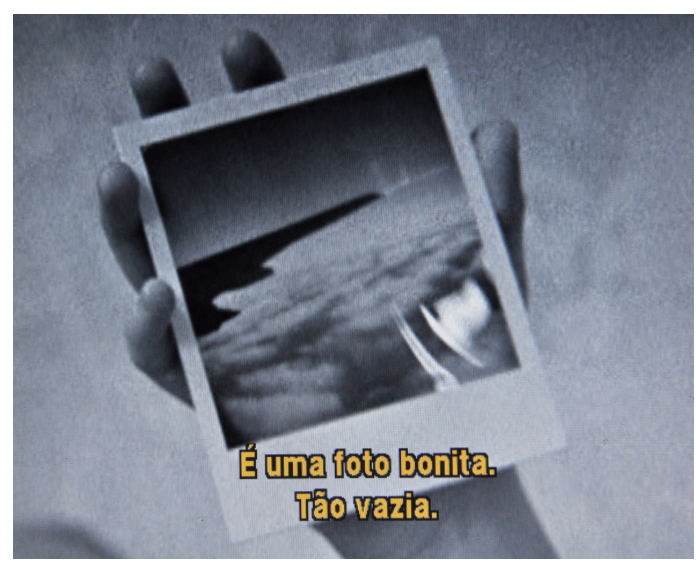

Figura 12 - A fotografia tirada por Phil surge na mão de Alice

Nesse plano detalhe da foto, percebemos mais uma idiossincrasia de Wim Wenders sobre essas superfícies vazias, essa no man's land (terra de ninguém). Quando há muito o que ver, quando uma imagem é muito cheia, ou quando há muitas imagens, não se vê nada. O cineasta acredita que "o muito" torna-se bem rápido "absolutamente nada". Ele prefere o efeito inverso. Quando uma imagem é quase vazia, muito despojada, é capaz de fazer surgir tantas coisas que chega a preencher totalmente o observador, transformando o vazio em tudo. ${ }^{34}$ Isso confirma-se na sua maneira de enquadrar os planos dos seus filmes. Em meio às imagens vazias e contemplativas, Wenders evoca os nossos sentidos.

Quando chegam a Amsterdã, a menina conta um sonho que teve para Winter. Mais tarde, à noite, para fazê-la dormir, ele decide lhe contar uma história. Estas duas seqüências são paralelas entre si. Elas permitem a Wenders, estabelecer os tais contextos de que ele fala na citação usada anteriormente. A viagem como sonho, mas, principalmente, como um processo de (re)construção de uma narrativa. Ele consegue ilustrar muito bem esse processo em uma cena de um passeio de barco entre os dois. Alice pede ao Winter para contar algo sobre ele. Confuso, hesita ao responder. Ela pega a câmera na bolsa dele e tira um retrato. Em seguida, ela entrega a foto para ele e diz: pelo menos agora você vai saber quem você é. Neste momento, há um corte para o detalhe do olhar de Winter e a fotografia. A fotografia é o texto das nossas vidas. Em cada uma delas, inscreve-se o nosso destino. Na fusão dessa imagem, Alice e Winter se tornam um só. Essa unicidade é o prenúncio de várias mudanças que vão ocorrer. Neste momento, o cineasta nos mostra, mais uma vez, a força da imagem. Foge, por completo,

${ }^{34}$ Wenders. A paisagem urbana. op.cit. pág. 185. 
da precariedade do significado da fotografia frente ao cinema. Essa fusão entre as imagens aparece como uma maneira de reconstituir a identidade, o grande drama das personagens. Parece que a fotografia muda de sentido ao longo do filme. Ela deixa de representar apenas as paisagens e o vazio existencial e passa a focar na essência dos personagens e, ao mesmo tempo, na força das imagens e da linguagem do cinema.

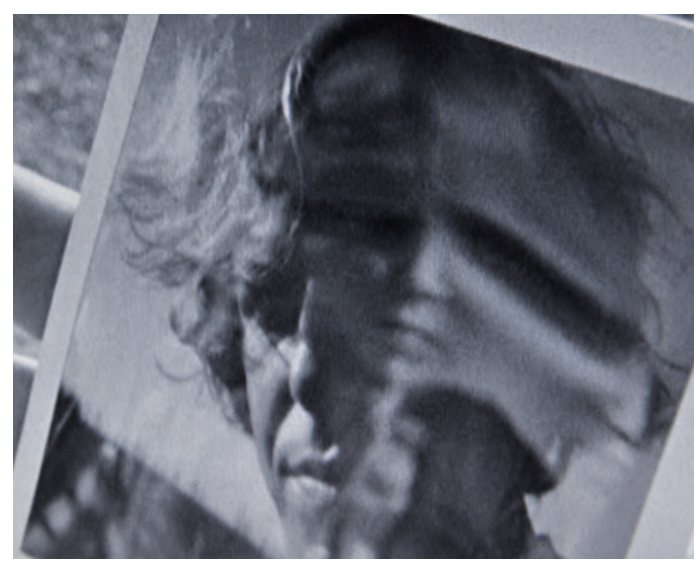

Figura 13 - Fusão da imagem de Phil e Alice na fotografia

Winter convence Alice para viajarem até Amsterdã. Alice disse, ao acaso, que a sua família morava em Wuppertal. Ela mostrou para ele uma foto, que retirou da carteira, da casa de sua avó. Após percorrerem, pela estrada, diversas cidades da Alemanha, Alice confessa que não tem muita certeza sobre o nome da cidade. Diz isso para ele, em um café, na Alemanha, ao som de um blues de Chuck Berry tocado por uma máquina de jukebox. O lado ameaçador e repetitivo do blues sublinha o conflito eminente, mas também projeta a história para a frente. Winter decide entregá-la à polícia. A história suspende-se. Interrompe-se. Ao sair da delegacia, Winter vê o cartaz de um concerto de Chuck Berry e decide ir ao concerto. Vemos ele beber uma CocaCola e, de certo modo, confessar a sua admiração pelos EUA.

Quando regressa, Alice espera por ele na porta do hotel. É difícil quebrar o elo entre eles. Winter fica contente de vê-la. Seguem viagem, mas desta vez o destino é a cidade de Ruhr. Novamente, a busca é fracassada. Mas nada abala o espírito deles: fazem jogging e tiram fotografias juntos.

Mais uma vez, Wenders usa uma cabine de fotografia instantânea nos seus filmes para "provar" aquilo que, de fato, aconteceu, que aquela felicidade foi "real". No entanto, o mais importante que ele enfatiza é o papel da imagem também como 
constituidora de uma memória pessoal, do profundo estreitamento dos laços entre os dois personagens.

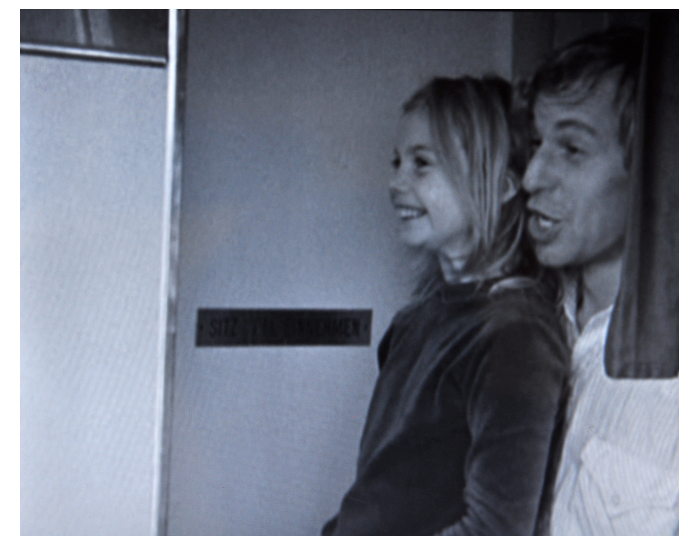

Figura 14 - Alice e Phil sorriem na cabine fotográfica

A viagem podia durar para sempre. Embora Alice ainda não saiba qual é o seu papel na vida de Philip Winter. A viagem prossegue, mas a policia continua à procura de Alice. Em uma viagem de barco, Winter é abordado por um policial. A mãe e a avó da menina a querem de volta. No entanto, os policiais têm ordens para embarcar Alice no primeiro trem para Munique. É Alice quem oferece 100 dólares para que ele compre a passagem. Quando ela lhe pergunta, já no trem: "O que você vai fazer em Munique?" Ele responde "Acabar esta história." Aqui temos um exemplo da subjetiva indireta livre pensada por Pasolini. Seria como se Wim Wenders entrasse na fala do personagem, assumisse a sua identidade e passase a ser o dono da história.

Em um plano aéreo dos dois à janela do trem, subimos em um travelling vertical, cada vez mais alto, até o enquadramento abranger todo o trem, o rio e as montanhas, estamos de volta ao avião do primeiro plano do filme, só que desta vez a perspectiva é inversa. No primeiro plano do filme, o travelling vertical desce do avião até encontrar o Winter, sozinho, sentado na areia da praia, embaixo de um pontão. Mais uma vez, o cineasta nos dá a noção dos delocamentos. O deslocamento da narrativa entre as paisagens, das identidades das personagens, dos movimentos de câmera e da própria estrutura transitória do road movie. 


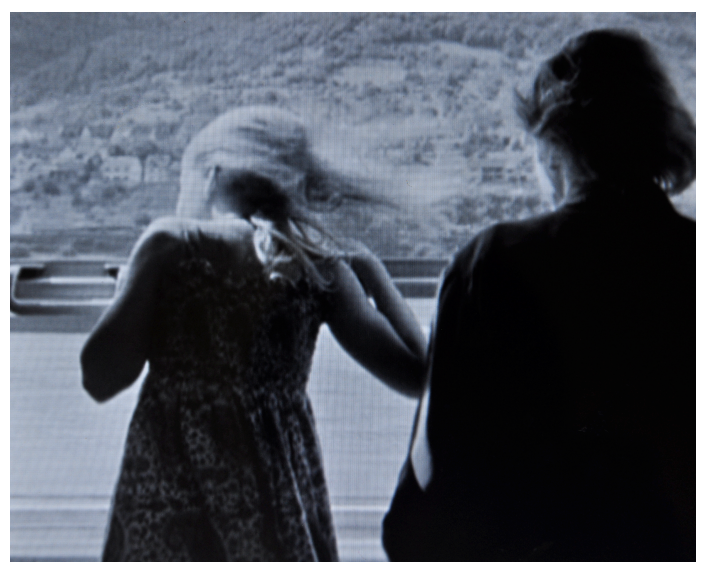

Figura 15 - Alice e Phil na janela do trem

A história ganhou asas e voou. Com ela assistimos à transformação da dúvida, da angústia, da depressão e do medo (o "medo de ter medo" como disse Winter à Alice) em ação, esperança, movimento. Este movimento é também parecido com a novidade que o cinema representa em relação à fotografia Polaroid e tantas outras linguagens (televisão, vídeo, imagem digital etc) que hoje, por mais ameaçadoras que sejam ao cinema, não deixam de ser recorrentes.

Mais uma vez, o protagonista da história e o realizador sofrem transformações similares. Com o filme Wenders ganhou definitivamente estatuto no cinema alemão, mas a diferença é que este filme marcou a filmografia do cineasta pela abordagem sensível com as personagens, na confiança que ele depositou no valor metafórico da viagem, na relação que estabeleceu com a imagem de cinema. Ao seu modo, soube usar a enumeração exaustiva de cidades americanas e alemãs para marcar um ponto na história do seu cinema. Um cinema influenciado fortemente pela iconografia norteamericana, mas que confia no uso ponderado e significativo do enquadramento, onde o travelling predomina contrariando o plano fixo, afastando-se de uma fotografia banal para abarcar a poesia das imagens em movimento.

Neste filme, Wenders inicia a sua trilogia dos road movies e questiona, por meio das personagens, a relação deles com os lugares, o expatriamento e a busca da identidade, a fotografia estática e a força dela na linguagem do cinema, a banalização das imagens pela televisão, o excesso de publicidade, o vazio das imagens e o vazio existencial das personagens, a relação confusa e deteriorada entre homens e mulheres, a incompreensão da escrita frente às imagens, a viagem e, principalmente, o início de uma 
questão que permeia muitos dos seus filmes: a incomunicabilidade frente a uma comunicação arbitrária. No entanto, nada é perene. A televisão, por exemplo, surge como um meio alienante, mas ao longo do filme, ela se torna um elo entre os personagens. Pretendemos demostrar, ao longo dessa pesquisa, que a assimilação da cultura americana também sofre modificações de sentido. Aquilo que foi, inicialmente, criticado passou-se a ser consumido: refrigerante, blues, rock, televisão etc. Passou-se, também, do exílio para a volta à pátria e isso coincide com alguns outros retornos: dos laços afetivos, da conciliação com a cultura de massa, da busca da identidade, inclusive, de uma maneira muito própria de fazer cinema. Isso será desenvolvido no próximo capítulo e ao longo da continuação dessa pesquisa. 


\title{
3. Incomunicação, solidão e silêncio - movimentos de interiorização e a representação da subjetividade no cinema
}

\author{
Solidão, o silêncio das estrelas, a ilusão \\ Eu pensei que tinha o mundo em minhas mãos \\ Como um deus e amanheço mortal. \\ Lenine (O silêncio das estrelas) \\ Difícil fotografar o silêncio. \\ Manoel de Barros (2000)
}

Diz o Littré $^{35}$ que o som é aquilo que a audição percebe devido ao efeito de movimentos vibratórios rítmicos. É sob esse aspecto que a Índia faz dele um símbolo fundamental. O som está na origem do cosmo. Se a palavra, o verbo (Vak), produz o universo, é através do efeito das vibrações rítmicas do som primordial (nada). Nada é a manifestação do som (shabda), da qualidade sonora, que corresponde ao elemento Éter (akasha). Tudo que é percebido como som, dizem os textos é xácti (força divina). O que é desprovido de som é o próprio Princípio. Quanto ao som, pode ser não manifestado (para), sutil (pashyanti) ou articulado (vaikhari). O som é percebido antes da forma, a audição é anterior à visão. De shabda nasce o bindu, ou germe da manifestação. Por analogia, o nascimento individual é às vezes designado como um som. O conhecimento não aparece como uma visão, mas como uma percepção auditiva (luz auricular, diz o Tratado da Flor de Ouro, em que é patente a influência tântrica). ${ }^{36}$

Apesar de esperarmos palavras e sons, tanto a literatura quanto a música são pródigas em produzir silêncios. A página em branco é uma promessa, é a maior dúvida de tudo aquilo que se quer dizer, de um porvir. A escritora Clarice Lispector, no seu $A$ hora da estrela, dizia que a palavra é tão forte que poderia atravessar a barreira do som. No entanto, a sua busca sempre foi realizar uma escrita em direção ao silêncio. Escrever, para ela, era uma fatalidade. Em seus livros, personagens situados entre o ato

\footnotetext{
${ }^{35}$ Émile Maximilien Paul Littré (Paris, 1 de fevereiro de 1801 - Paris, 2 de junho de 1881) foi um lexicógrafo e filósofo francês, famoso pela autoria do Dictionnaire de la langue française, mais conhecido como o Littré.

${ }^{36}$ Verbete extraído do Dicionário de Símbolos. CHEVALIER, Jean. GHEERBRANT, Alain. p. 841.
} 
de ver e o momento de conhecer, submetidos às forças aleatórias da ausência, buscam uma comunhão com o inexprimível, com o silêncio inenarrável. O escritor em seu ofício descortina palavras, escava verbos, busca os silêncios. Essa é a escritura de Clarice. Uma escritura que está às voltas com um semi-dizer, um dizer não-todo ou meio-dizer, no sentido lacaniano ${ }^{37}$, porque nele não há respostas, apenas questões. Poderíamos imaginar um filme com as imagens literárias da escritora; imagens distantes, obscurecidas, que restam como uma paisagem na neblina.

Para Wim Wenders e os filmes por ora analisados, o cineasta russo Andrei Tarkovski também é outra fonte de inspiração quando pensamos em cinema, literatura, solidão e silêncios. Talvez, uma boa metáfora para nos lembrar de tudo isso seja a figura de um relógio inerte, na parede, com o barulho distante e não menos ensurdecedor do vagar de seus ponteiros. Em seu livro emblemático Esculpir o tempo, não por acaso, esse tempo lento e fugidio é impresso na maneira que ele deixa rastros e vestígios. Já nos filmes de Wenders, essa lentidão se comprova pelo próprio vagar dos personagens pelas estradas, pela contenção dos gestos mínimos, quando um personagem olha subjetivamente para o mar (Alice nas Cidades), passeia de bicicleta por campos infindáveis (Movimento em Falso) ou quando conserta, lentamente, a bobina de um antigo projetor (No Decurso do tempo).

De maneira poética, Wenders também “esculpe o tempo" diegético de seus filmes. Tarkovski disse que assim como o escultor toma um bloco de mármore e elimina tudo tudo que não faz parte da obra, o cineasta , a partir de um "bloco de tempo", corta e rejeita tudo que não necessita. Ou seja, deixa apenas tudo aquilo que será um elemento do futuro filme. Muitas vezes, esse filme pode ser considerado o substrato de toda uma vida, repleta de percalços, dúvidas, anseios e poesia. É essa poesia que Tarkovski perseguiu em quase todos os seus filmes que, por sua vez, serviu de espelho para muitos cineastas. Os seus filmes se afastavam do real pois captavam a vida como um reflexo, como um sonho e, por isso, davam origem a símbolos, alegorias e outras figuras do gênero. Uma obra marcada por um profundo sentido espiritual, que marcou um cinema intimista, conciso, com os olhos voltados para os detalhes que se perdem no silêncio.

\footnotetext{
37 Termo assimilado do livro de ROUDINESCO, Elisabeth. Lacan a despeito de tudo e de todos. Rio de Janeiro : Zahar, 2011. p. 95.
} 
Os espectadores dos seus filmes sentiam-se aturdidos e, de certa forma, desorientados. Tarkovski penetrava no mundo emocional de adultos e crianças, fazianos sentir a beleza do mundo que nos circunda, transformava cada detalhe do filme num símbolo, exprimia um significado filosófico geral a partir de uma extraordinária economia de meios, além de encher com uma poesia silenciosa cada imagem de cada fotograma.

Certa vez, uma senhora the enviou uma carta que fora escrita pela filha e nela expressava o quanto os seus filmes poderiam ser vistos como uma criação artística sob a forma de comunicação sutil e versátil. Ela dizia assim: ${ }^{38}$

\footnotetext{
“...Quantas palavras uma pessoa conhece?”, pergunta ela à mãe. "Quantas ela usa na sua linguagem cotidiana? Cem, duzentas, trezentas? Envolvemos os nossos sentimentos em palavras e tentamos expressar através delas a tristeza e a alegria e todo tipo de emoções, exatamente aquelas coisas que, na verdade, são impossíveis de expressar. Romeu disse belas palavras a Julieta, palavras vivas e expressivas, mas ela certamente não disseram nem a metade daquilo que dava a Romeu a sensação de que o coração ia saltar-lhe do peito que lhe prendia a respiração, e que levava Julieta a esquecer-se de tudo, exceto do seu amor.

"Existe um outro tipo de linguagem, uma outra forma de comunicação: a comunicação através de sentimentos e imagens. Trata-se do contato que impede as pessoas de se tornarem incomunicáveis e que põe por terra as barreiras."
}

Para ser fiel à vida e intrinsecamente verdadeira, Tarkovski achava que as obras deveriam ser, ao mesmo tempo, um relato exato e efetivo de uma verdadeira comunicação de sentimentos. Talvez seja isso o que o identificava tanto com Dostoievski. Para ele, os personagens mais interessantes são aqueles exteriormente estáticos, mas interiormente cheios da energia de uma paixão avassaladora.

Filmes de estrada são bem assim. Nos road movies, o silêncio prepondera e ecoa nas subjetividades. Podemos imaginar os movimentos escassos. Travellings contidos e lentos de estradas pouco habitadas, e permanentes na sua distância, as longas panorâmicas do deserto no oeste americano e fotografias em ângulos onde a ênfase é no céu muito claro, de um azul cheio de agressividade, e uma poeticidade que berra, de tão explícita. Nos filmes em preto e branco, o tom é dado pela essência do viver. Tudo com muitos poucos cortes e, ao mesmo tempo, conduzindo o sentido do olhar para um estado de silêncio e prolongamento. Nesses filmes, são recorrentes os planos mais econômicos

${ }^{38}$ TARKOVSKI. Esculpir o tempo. São Paulo: Martins Fontes, 1990. p. 8. 
ou mesmo intimistas, que favorecem a presença pungente dos personagens e de seus estados de ânimo.

Wim Wenders persegue essas proposições desde o seu primeiro longa-metragem. A fuga, o deslocamento, a incomunicabiliade e a solidão são características das sensações, possivelmente, apreendidas nos quadros melancólicos e silenciosos do pintor americano Edward Hopper, uma referência importante no cinema de Wenders. Na miseén-scène desses filmes, muitas vezes, o campo visual da câmera é composto pela parte frontal do carro, com destaque para os retrovisores e o pára-brisa voltado para a infinitude da estrada. O reflexo dos personagens em vidros e espelhos, na maioria das vezes, serve como metáfora da projeção do personagem na paisagem na qual ele viaja, na sua busca por um mundo idílico.

Feito de incomunicabilidades e de busca de identidades, é um cinema de tempos mortos, que antecede momentos transparentes onde a narrativa fica, por vezes, suspensa, como se desprovida de peso, detendo-se sobre um gesto, um sinal, uma palavra, um silêncio ou apenas uma imagem. Um cinema espantosamente concreto e, no entanto, um deslocamento constante. Filmes de estrada são filmes repletos de silêncios, aridez, solidão. A personagem, na maioria das vezes, está sempre em busca de algo ou alguém. Mas, no fundo, esse busca gira em torno de si mesmo.

Esse tipo de filme, muitas vezes, é considerado literário. Tarkovsky, no seu Esculpir o tempo, já havia dito que algumas obras possuem uma grande unidade no que diz respeito aos elementos que a constituem, e a imagem literária que nela se manifesta é original e precisa. Os personagens são de uma profundidade insondável, a composição tem uma extraordinária capacidade de encantamento, e o livro é indivisível. O cineasta russo considerava que esse livros são obras-primas, e filmá-los, ao seu ver, é algo que só pode ocorrer a alguém que, de fato, sinta um grande desprezo pelo cinema e pela prosa de boa qualidade.

Tarkovsky tinha uma afinidade com o cinema e as suas articulações poéticas, com a lógica da poesia. No entanto, essa afinidade não se ligava com qualquer cinema. Mas 
com um cinema mais complexo, permeado por um universo filosófico de poesia (1990, p. 16).

Parecem-me perfeitamente adequadas ao potencial do cinema enquanto a mais verdadeira e poética das formas de arte. Estou muito mais à vontade com elas do que com a dramatrugia tradicional, que une imagens através de um desenvolvimento linear e rigidamente lógico de enredo.

Essa verdade do cinema é refletida por uma mise en scène. ${ }^{39}$ Ela se dá por meio da posição dos atores entre si, em relação ao cenário. Podemos dizer, então, que é fundamental que a mise en scène ao invés de ilustrar alguma idéia, exprima a vida - o caráter dos personagens e seu estado psicológico.

Segundo Tarkovski, a chave da poesia do cinema nasce da observação da vida. Um exemplo bem lírico que fascinava Eisenstein, além do próprio cineasta, é encontrado neste haicai ${ }^{40}$

\author{
Enquanto passa \\ A lua cheia mal toca \\ Os anzóis entre as ondas.
}

Assim como o cinema, o haicai é a observação em estado puro. Assim como o encadeamento dos fotogramas do cinema (sintagmas), a combinação de três elementos é capaz de criar algo que é diferente de cada um deles. Tarkovski se sentia arrebatado pelos filmes do Eisenstein. O Encouraçado Potemkin, por exemplo, é citado como um filme cheio de vida e de poesia. No entanto, ele se sentia irritado com as afetações e

39 Segundo Fernão Ramos, em seu artigo “A mise-en-scène realista: Renoir, Rivette e Michel Mourlet”"o conceito de 'mise-en-scène' define, entre outros elementos, o espaçamento de corpos e coisas em cena. Vem do teatro, do final do século XIX/início do XX, e surge com a progressiva valorização da figura do diretor, que passa a planejar de forma global a colocação do drama no espaço cênico. Penetra na crítica de cinema na década de 50, quando a arte cinematográfica afirma sua singularidade estilística deixando para trás a influência mais próxima das vanguardas plásticas. Mise-en-scène no cinema significa enquadramento, gesto, entonação da voz, luz, movimento no espaço. Define-se na figura do sujeito que se oferece à câmera na situação de tomada, interagindo com outrem que, por trás da câmera, lhe lança o olhar e dirige sua ação. Na cena documentária, o conceito de mise-en-scène desloca-se um pouco e pousa, de forma mais solta, na fagulha da ação da circunstância da tomada". Disponível em http://www.iar.unicamp.br/docentes/fernaoramos/20Mise-enSceneSiteRealista.pdf $\quad$ Acessado em $12 / 03 / 2015$

40 Haicai de Robert Bird retirado em Andrei Tarkovsky: elements of cinema, Reaktion Books, 2008, p. $199-200$ 
preciosismos do moderno "cinema poético", repletos de um simbolismo vazio, câmeras na mão e tomadas embaçadas.

Buñuel e Kurosawa, por exemplo, são citados no livro de Tarkovsvski pela capacidade de as suas imagens expressarem um fato específico, único e verdadeiro. A mise en scène dos seus atores passa uma naturalidade impressionante. Por outro lado, o papel do roteirista também é evidenciado. É importante que ele tenha um talento literário para criar perfis psicológicos de determinadas personagens, além de ser responsável, em um trabalho de estreita parceria com o diretor, pela atmosfera do filme. Tarkovski enfatiza que a obra do autor nasce do seu pensamento, da sua intenção, da necessidade de dar seu depoimento sobre algo importante. Para ele, existem poucos gênios no cinema. Bresson, Mizogushi, Dovjenko, Paradjanov e Buñuel têm um jeito único de filmar e nenhum deles pode ser confundido com outro.

Em seu artigo intitulado "Robert Bresson: o cinema num atormentado silêncio", Susana Dobal descreve algumas características fundamentais desse cineasta que soube trabalhar essa "silenciosa precisão" nas telas. Para Dobal, Bresson recorreu frequentemente ao silêncio como uma forma de fazer com que os gestos e os seus objetos se tornassem falantes e os sons voltassem a ser realmente sonoros (DOBAL, 2003, p. 275).

Para ele, o cinema deveria dizer o que outras artes não podiam expressar, isto é, era necessário que houvesse o pleno conhecimento e aproveitamento dos seus recursos, pois só assim o cinema poderia ser empregado como uma forma de descoberta do mundo. A opção pelo silêncio vem atender essa demanda.

O cinema, em seus filmes, não é usado de maneira aleatória. No filme $A u$ hasard Balthazar, por exemplo, ele cria um ar de descoberta, como se as coisas estivessem sendo vistas pela primeira vez. Esse estranhamento se dá pelo fio narrativo que, de maneira simples, mas não menos complexa, segue o percurso passivo de um asno, seus diversos donos, fatos desconexos, encontros fugazes e mais ou menos arbitrários com as pessoas e os diálogos que elas deixam pelo seu caminho. Uma cena emblemática do filme é a famosa sequência da troca de olhares do burro com outros animais do circo. Embora nada seja dito nesse diálogo de olhares, ele é pungente. Pela carga dramática do silêncio, vemos uma cumplicidade muda entre os animais atrás das grades. Esse aprisionamento também é uma outra marca dos personagens de Bresson. De certa 
forma, todos estão distanciados da vida ao seu redor, e os filmes narram a tentativa vã de encontrar uma saída para esse mundo exterior.

Dobal faz, ainda, uma comparação poética entre o cinema e a teoria musical para adentrarmos, ainda mais, nesse universo bressoniano. Assim como percebemos uma pausa proposital no meio da execução de uma partitura, também passamos a ouvir a ausência das palavras no laconismo de seus filmes. No entanto, enfatiza, que tudo é construído para que as palavras não façam falta, conforme nos detalha em seu artigo:

\begin{abstract}
Mouchette arrasta os seus pesados tamancos e o som exagerado dos seus passos são um sintoma da sua impossível adequação na trilha sonora doméstica. Em Lancelot du Lac o barulho insistente das ferraduras, dos arreios e da mistura de couro e metal intercalando os cavaleiros e seus cavalos criam uma ambientação ruidosa tão ou mais poderosa do que um cenário que mostrasse a localização histórica do enredo. Isso ocorre porque mais do que dar uma informação que ajude na compreensão do enredo do filme, Bresson está interessado em produzir sensações capazes de oferecer alguma revelação.
\end{abstract}

Ele pensa no som e, até mesmo na ausência dele, com uma espécie de força imagética reveladora. Isso nos remete, novamente, ao início do capítulo quando mencionamos o mito indiano que valoriza o som como a origem do cosmo, que enfatiza, sobremaneira, a sua primazia frente à visão, pois, para eles, o som vem antes da forma. É por meio da audição que assimilamos o conhecimento. Para Bresson, o olho, muitas vezes, é superficial, mas a orelha é profunda e inventiva, pois o barulho de um apito de trem, por exemplo, traz toda a lembrança de uma pequena estação. $O$ silêncio que percebemos não se trata de um silêncio total, mas sim um silêncio de palavras. O som é presença e ausência, e está, por menos que isso apareça, permeado de silêncio. Há tantos ou mais silêncios quantos sons no som, e por isso se pode dizer, com John Cage, que nenhum som teme o silêncio que o extingue (WISNIK, 2006, p. 18). Os sons, assim como as imagens, tem o seu léxico e nos falam de uma maneira própria. $\mathrm{O}$ som tem um poder mediador, hermético: é o elo comunicante do mundo material com o mundo espiritual e invisível. Nos filmes de Wenders, por exemplo, um simples sobrevoar de um avião que rompe os céus, traz consigo um barulho ensurdecedor frente à calma de uma melodia assoviada por um personagem enquanto contempla o ir e vir das ondas do mar. Foi isso que ouvimos pelos olhos subjetivos de Philip Winter nesse momento de sinestesia (fusão dos sentidos) no filme Alice Nas Cidades. O ruído do 
avião pontua a poética de um silêncio contemplativo que, por mais perturbador e inquisitivo que seja, insiste em ficar.

Separar os sons das imagens foi um outro método que o cineasta utilizava para tirar o máximo proveito do som. Bresson gostava de testar os espectadores ao utilizar a impaciência de só ouvir ou só ver. A seu modo, buscava aproveitar outros recursos expressivos que não apenas a ênfase nas palavras. A partir disso, podemos perceber algumas diferenças entre o cinema de Bresson se comparado ao jeito de filmar de Tarkovski. Enquanto Tarkovski também explorava o silêncio, mas preferia enfatizá-lo em planos estáticos e longos, Bresson povoa seus silêncios de sons, mas também de imagens, ações e gestos, essencialmente, reveladores. Talvez seja esse seu jeito de filmar que acabou por conquistar Andrei Tarkovski. No papel de cineasta e admirador confesso, ele admirava a obra de Bresson por achá-la longe de um cinema espetáculo, mas algo muito parecido com a própria vida. Por outro lado, o som da água, por exemplo, água correndo, água pingando, é bastante presente em alguns filmes de Tarkovski. Tal qual Bresson, ele exagera no volume para tornar mais presente a sensação e, ao mesmo tempo, enfatizar a densidade daquele elemento do cenário.

Podemos, de alguma forma, resumir algumas características desse cinema com uma linguagem tão especial. Um cinema calcado na força dos gestos, com uma ênfase nas mãos dos atores, que não deixava escapar o rigor em representar uma atuação quase que natural, na maioria das vezes, repetida à exaustão. Para ele, o sobrenatural está no gesto espontâneo. Isso fica nítido quando percebemos que o seu olhar se volta para um certo interesse profundo pelas personagens, sem se esquecer dos mistérios carregados pelas pessoas e objetos. O silêncio, nos filmes de Bresson, é afirmado como algo libertador ou até mesmo massacrante. A força do seu silêncio está no potencial do próprio silêncio. Conforme mencionou Dobal, Bresson nos faz apreciar o seu uso do silêncio como uma fala cinematográfica, mas também como um depoimento de alguém imerso no mundo com os olhos abertos e os ouvidos atentos.

\section{Um silêncio poético}

O professor e pesquisador Adalberto Müller nos conta que as primeiras tentativas de definir uma certa noção de cinema poético surgiram na década de 20 . 
(Müller, 2012, p. 210). Jean Epstein, por exemplo, deu algumas definições da maneira que isso poderia ser entendido e assimilado. Ele defendia que o cinema se tornava artístico a partir da definição de fotogenia. Epstein também reforçava o uso do close-up e da câmera lenta como dispositivos que permitiam alterar a percepção das coisas e, ao mesmo tempo, demarcar esse território poético na tela do cinema:

\begin{abstract}
Epstein valorizou as noções de fotogenia e de ritmo, considerando que tanto a plasticidade quanto os movimentos de câmera são capazes de extrair das coisas do mundo significados recônditos que sua existência prosaica retém. O poético se manifestaria, assim, no ponto em que o discurso fílmico, decompondo "um fato em que seus elementos fotogênicos", libertar-se-ia da lógica da seqüencialidade do relato e, através dos recursos técnicos de que se constitui, revelaria a essencialidade de um gesto, de um objeto, de um sentimento (Maciel apud Müller, 2004, p.71).
\end{abstract}

Em 1960, Pasolini desenvolveu o conceito de cinema de poesia que poderia ser aplicado a muitas obras do cinema contemporâneo; um cinema que acentua, ainda mais, a subjetividade da narrativa. Foi criação sua aquilo que é chamado na linguagem do cinema de "subjetiva indireta livre", conforme citamos anteriormente, que vem a ser a utilização do personagem para passar questões que concernem o cineasta. Na Nouvelle Vague, por exemplo, existem alguns filmes que trazem dentro de si um outro filme. Este segundo filme é aquele que o autor não pode ou teve coragem de fazer. Isso não quer dizer que não existam filmes onde o autor conte a história em primeira pessoa. $\mathrm{O}$ estilo não consiste apenas em fazer de si o objeto da obra, mas em ver o mundo através de si mesmo, interiorizar o mundo.

Pasolini via o cinema como uma espécie de plano-sequência infinito carregado de subjetividades. De certa forma, essa definição nos aproxima dos filmes analisados nesta tese. Road movies são estruturados por meio de personagens que seguem por uma estrada sem saber direito aonde aquilo vai dar. Esse caminhar, muitas vezes, é solitário, cheio de acasos, silêncios e incertezas. O viajante, pela estrada afora, ouve os ruídos dos seus próprios passos entremeados pelos motores dos carros que passam ao longe, a presença do silêncio empresta ao cinema a força poética de uma escritura que não se solidifica com a palavra, mas ecoa no encadeamento das escolhas imagéticas. Na dança da solidão, dos silêncios e das subjetividades, os personagens dos road movies têm a literatura como par. 


\subsection{Movimento em falso - um cinema contemplativo}

Pelo ar, o estranhamento. Ao longo de quase dois minutos, a câmera sobrevoa uma cidade fria, chuvosa e cinzenta, acompanhada de um som repetitivo, com um certo ar de suspense, até adentrar a janela de dentro do quarto de um apartamento. A câmera subjetiva nos mostra o personagem que se encontra de frente para uma janela, com um olhar tristonho observa as pessoas que passam por uma praça. A trilha, a partir dessa cena, é um rock and roll rasgado que toca na vitrola. Em seguida, a câmera acompanha o personagem caminhando até a vitrola, escolhe uma faixa do disco, com um plano detalhe para uma capa de um disco do "The troggs". O som aumenta, repentinamente, e ele volta a caminhar, com uma cara absorta, até a janela. Olha para um casal de idosos que caminham pela praça e parecem observá-lo na janela e, de maneira tão inusitada quanto abrupta, dá um soco na janela. Com a mão sangrando, volta em direção à vitrola e levanta a agulha do disco. Um silêncio arrebatador invade o quarto. Ele ergue a mão até a boca, e lambe, vagarosamente, o sangue entre os dedos. A câmera se direciona até a porta e mostra a mãe, com uma cara de enfado, mirando os olhos dele. Ao lado dela, na estante, vemos um detalhe da capa de um livro do William Faulkner chamado "Moskitos". Em seguida, a câmera corta para o rosto dele e, neste momento, ele enxuga as lágrimas que escorrem pelo rosto, enquanto observa, na mais profunda tristeza, a mãe prostrada à sua frente. Ela esboça uma tentativa de balbucio, titubeia, um pouco, com a cabeça, vira-se em direção à porta e sai.

$\mathrm{Na}$ cena seguinte, o personagem se encontra sentado sobre a banheira, enquanto desenrola uma faixa para proteger a mão machucada. A mãe se dirige até a porta e brada de maneira impiedosa: "Quero que você vá embora daqui". Ao longo de três minutos e quarenta do filme Movimento em Falso (Falsche Bewegung, 1975), essa é a primeira fala que rompe o silêncio do ambiente.

A aspereza, a incomunicação e a imobilidade fazem um contraponto com o próprio título do filme. Um personagem marcado por um "movimento atávico", ancorado feito um barco bêbado no seu próprio quarto, prisioneiro, dele mesmo, em um estado de puro isolamento, na mais completa solidão. Em diversos trabalhos de Wenders, a narrativa é composta por alguma situação de um personagem que viaja, seja 
de trem, carro, ou a pé. A estrada é sempre um elemento fundamental e constante. No entanto, alguns outros componentes também complementam essa "marca" do diretor. Seus personagens estão sempre deslocados, em trânsito, despatriados, sem relações estáveis e duradouras. Já neste filme, que segue como o segundo da sua trilogia on the road, Wenders escreveu um roteiro fluido e livre de linearidade. A estrada é substituída pela errância do personagem em busca de si mesmo e da sua possível escrita. Movimento em Falso foi inspirado no texto Os Anos de Aprendizado de Wilhem Meister, de Goethe. Conforme vimos no plano descrito acima, o aspirante a escritor Wilhem Meister (Rudiger Vogler) deixa para trás sua mãe opressora e sua casa e, por fim, resolve partir em uma jornada silenciosa pela estrada.

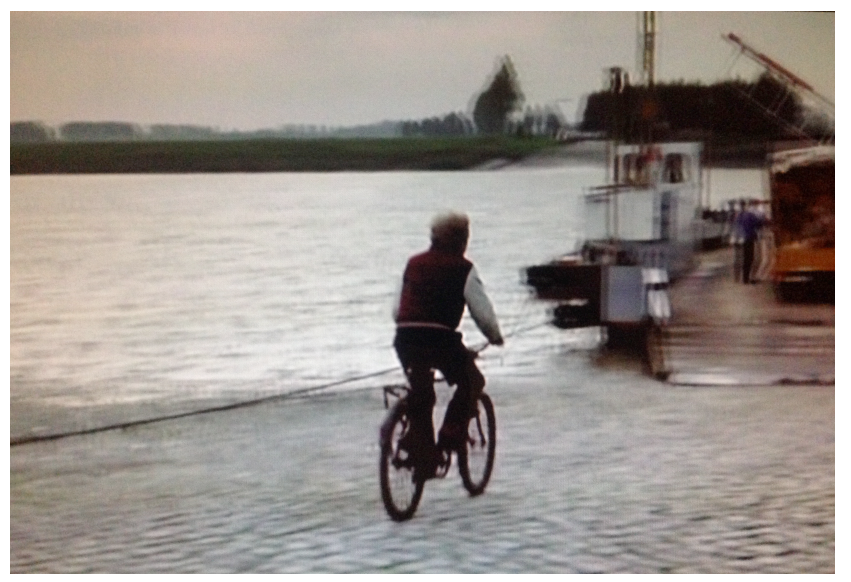

Figura 16: Wilhelm sai de casa em busca da sua escrita e de si mesmo

Sem rumo definido, ele segue sua rota e encontra pelo caminho uma série de personagens interessantes e figuras bizarras. Em sua errância, acaba por formar um grupo peculiar composto por um ex-atleta hitlerista (Hans Christian Blech), uma jovem contorcionista (Nastassja Nakszynski - ela ficou conhecida como Natassja Kinski), uma atriz (Hanna Schygulla) e um poeta medíocre (Peter Kern). No filme, temos duas representações: a formação identitátria do indivíduo e a do coletivo (amigos que ele faz ao longo da jornada), que se organiza em função do primeiro (Wilhem), mas que acaba, irremediavelmente fragmentada, no final do percurso, quando todos seguem sozinhos.

Em busca da solidão para satisfazer seu desejo de escrever, Wilhem encontra um destino para terminar sua viagem: Zugspitze, uma montanha nos Alpes Bávaros, na 
Áustria. No caminho do mundo de Goethe e do espectro da Alemanha Nazista, o percurso de Wilhelm segue na tentativa de construir a sua própria lógica. Em seu bojo, o movimento, de início, não é excludente, não recusa indivíduos e suas histórias, cujos sonhos e anseios podem se tornar matéria-prima para anotações, escrita e romance. Mas, ao mesmo tempo, não os tornam parte integrante do seu desenvolvimento pessoal, interior, sobretudo porque tais personagens não afetam, e, de alguma forma, não geram envolvimento, emoção. Assim, a partir de algum ponto do território alemão, a viagem de Wilhelm à cidade de Bonn agrega alguns personagens que vão aparecendo no meio do caminho, buscando uma certa totalidade do enredo ao retirá-los da condição de figurantes para o centro da narrativa. Especificamente porque, a um escritor em formação, o mundo de suas experiências constitui-se em matéria para o engenho e a arte da literatura. Entretanto, para preencher uma ausência, o movimento do personagem em busca de algo, ainda indefinido, só assimila as pessoas ao redor no momento em que a experiência começa a ser vivida.

Em contraposição às narrativas fundadas no bildungsroman, Wim Wenders tem seu herói distante das afetações em relação ao outro e ao mundo. A lógica de sua travessia pertence à solidão, e, a cada sequência, os personagens entram em deslocamento para chegar a algum lugar (Bonn, Frankfurt), encontrar a força não localizada (talento) e recolher os elementos para a formação, especificamente a experiência do mundo vivido e não, necessariamente, observado, como lembra Wilhelm em um diálogo. Movido por algum impulso, o personagem que parece insensível, não sente qualquer afetação nem mesmo pelo seu corpo, quando, logo na abertura, arrebenta o vidro da janela e sua própria mão, conforme descrevemos na cena inicial.

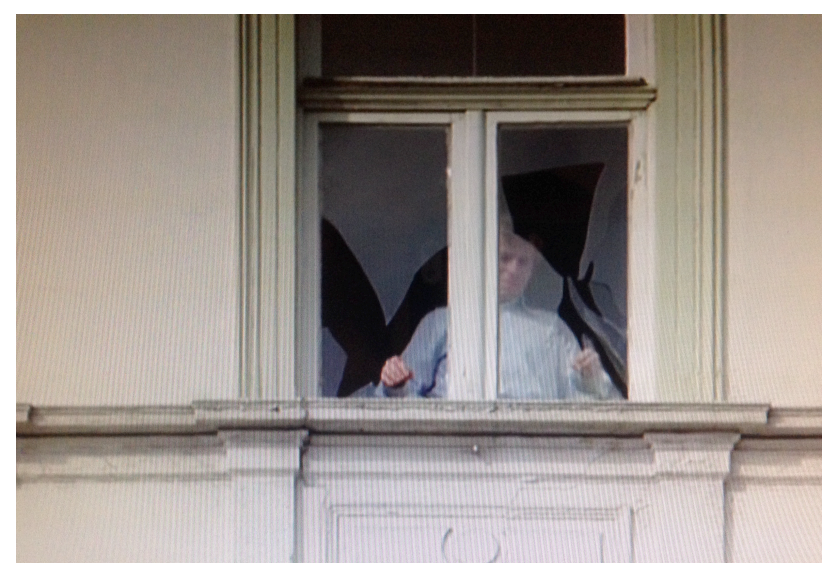

Figura 17: Wilhelm dá um soco na janela em um momento de raiva e frustração 


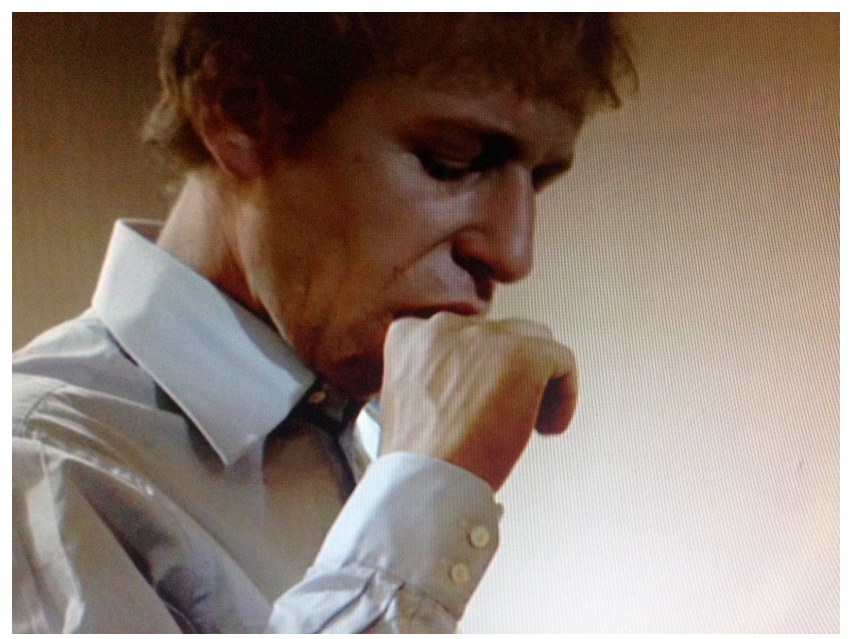

Figura 18: A dor é outra. Ela não se reflete na mão machucada

Afetação que não sentimos pelo próprio Wilhelm, afinal a câmera, numa das seqüências iniciais, o abandona à mesa de um restaurante em frente ao mar a escrever em sua caderneta de anotações: "uma câmera preocupada com as ausências". A câmera constitui-se, assim, apenas em imagem, quando se move em direção ao mundo e recusa o narrador sem talento.

Conforme bem observou o pesquisador Felipe (2007), o movimento de Wilhelm, demarca afastamentos constantes. Ao localizar seus personagens em deslocamento, Wenders desenvolve um filme onde o vagabundear é norma moldando a travessia como dimensão em si. Em "Movimento em Falso", a própria mãe de Wilhelm, ao despedir-se do filho, lembra que é preciso não ter medo quando lhe perguntarem do ofício inútil de ser escritor. Viajar por viajar, portanto, domina os personagens, especificamente Wilhelm e o casal de artistas que encontra no vagão do trem em direção a Bonn: o cantor (Peter Kern) e a jovem contorcionista (Nastassja Kinski), em sua primeira aparição nas telas de cinema. No entanto, do início ao fim, a travessia constitui-se no espaço, onde, em movimento, fuga ou liberdade, os indivíduos perdem o "afeto" e os "amigos" de estrada (Wilhelm), fogem de alguma ameaça (o cantor) e/ou se salvam de alguma forma de prisão (Kinski). Com parceiros que, permanentemente, o acompanham em seus projetos de cinema, Wenders tem na fotografia de Robby Muller um certo cromatismo meio envelhecido com se os personagens fossem vivendo uma história contaminada por um passado. 
O roteiro de Movimento em Falso foi escrito por Peter Handke. A partir dele, consolida-se a parceira e o segundo encontro fílmico entre o escritor e o cineasta Wim Wenders. Esse romance é considerado por muitos críticos literários como um dos prenúncios do moderno Bildungsroman, ou romance de formação, cujo "conteúdo é a educação dos homens para a compreensão prática da realidade" (LUKÁCS, p.592, 2006). Em uma entrevista dada para a pesquisadora Simone Malaguti (2004), Wim Wenders nos conta como surgiu a idéia do filme:

Simone Malaguti: E em Falsche Bewegung ? O sr. partiu do texto de Handke ou se inspirou em Goethe primeiramente?

W.W: Peter e eu decidimos fazer um filme juntos que se baseasse no material de Goethe, mas que não fosse simplesmente uma filmagem do romance Wilhelm Meisters Lehrjahre (Os anos de aprendizagem de Wilhelm Meister), do qual nos dois sempre gostamos muito; mas que fosse um filme que contasse a mesma história, tomando o romance como substrato. E nós percebemos que não era mais possível contar a mesma história hoje, pois somente o contrario dela era possível. A ânsia, ainda totalmente possível de ser vivida no século XIX, essa ânsia de sair pelo mundo, de se encontrar, de encontrar seu caminho, de aprender algo e ainda retornar como homem feito, essa era uma ânsia e que nós a descrevemos como impossível e, finalmente, como um caminho errado no século XX. E e por isso que o filme se chama Falsche Bewegung, pois ele conta, por assim dizer, como esse movimento era possível e ainda frutífero em Goethe.

No filme, não por acaso, acompanhamos toda a dificuldade dessa narrativa de Wilhelm acontecer. Santiago (2002), nos conta sobre as quatro questões básicas que acometem o narrador na pós-modernidade. Quem narra uma história é quem a experimenta, ou quem a vê? Ou seja, é aquele que narra ações a partir da experiência que tem dela, ou é aquele que narra ações a partir de um conhecimento que passou a ter delas por tê-las observado em outro?

No primeiro caso, o narrador transmite uma vivência; no segundo caso ele passa uma informação sobre outra pessoa. No primeiro caso, a narrativa expressa a experiência de uma ação; no outro, é a experiência proporcionada por um olhar lançado. Num caso, a ação é a experiência que se tem dela, é isso que empresta autenticidade à matéria que se tem dela e ao relato, no outro caso, é discutível falar de autenticidade da experiência e do relato porque o que se transmite é uma informação obtida a partir da observação de um terceiro.

Ainda segundo Santiago, questões sobre a autenticidade também devem ser discutidas. Só é autentico o que eu narro a partir do que eu experimento, ou pode ser 
autêntico o que eu narro e conheço por ter observado? Será sempre o saber humano decorrente de uma experiência concreta de uma ação, ou o saber poderá existir de uma forma exterior e essa experiência concreta de uma ação? Ao contrário do narrador clássico, inicialmente, o nosso narrador olha para se informar e não com o que narra mergulhado na sua própria experiência.

Para Benjamin os seres humanos estão se privando hoje da "faculdade de intercambiar experiência", isto porque as ações da experiência estão em baixa, e tudo indica que continuarão caindo até que se valor desapareça de todo". À medida que a sociedade se moderniza, torna-se mais e mais difícil o diálogo enquanto troca de opiniões sobre ações que foram vivenciadas. Assim como o nosso personagem principal - Wilhelm -, as pessoas já não conseguem hoje narrar o que experimentaram na própria pele. Dessa forma, Benjamin pode caracterizar três estágios evolutivos por que passa a história do narrador. Primeiro estágio: o narrador clássico, cuja função é dar ao seu ouvinte a oportunidade de experiência (único valorizado no ensaio); segundo: o narrador do romance, cuja função passou a ser a de não mais poder falar de maneira exemplar ao seu leitor; terceiro: o narrador que é jornalista, ou seja, aquele que só transmite pelo narrar a informação, visto que escreve não para narrara ação da própria experiência, mas o que aconteceu com x ou y em tal lugar e a tal hora (SANTIAGO, 2002, p. 46). Para Benjamin, a narrativa é narrativa "porque ela mergulha a coisa na vida do narrador para depois retirá-la dele".

O narrador pós-moderno é aquele que transmite "uma sabedoria" que é decorrência de uma experiência alheia a ele, visto que a ação que narra não foi tecida na substância viva da sua existência. Nesse sentido, ele é o puro ficcionista, pois tem de dar "autenticidade" a uma ação que, por não ter o respaldo da vivência, estaria desprovida da autenticidade. Esta advém da verossimilhança, que é produto da lógica interna do relato. O narrador pós-moderno sabe que o "real" e o "autêntico" são construções de linguagem. Ele é aquele que quer extrair a si da ação narrada, em atitude semelhante à de um repórter ou de um espectador. Pode-se narrar uma ação de dentro dela, ou de fora dela. Para testemunhar do olhar e da sua experiência é que ainda sobrevive a palavra escrita na sociedade pós-industrial. 
A ficção existe para falar da incomunicabilidade de experiências: a experiência do narrador e do personagem. A incomunicabilidade, no entanto, se recobre pelo tecido de uma relação, relação esta que se define pelo olhar. Uma ponte, feita de palavras, envolve a experiência muda do olhar e torna possível a narrativa. No entanto, as narrativas, hoje, conforme pontuou Santiago (2002, p. 54), são, por definição, quebradas. Sempre a recomeçar.

Segundo Gonçalo (2013), o então escritor e dramaturgo Peter Handke, em uma espécie de lampejo, escreveu direto o roteiro, sem passar por uma escrita literária prévia, e escolheu mudar a "cronotipia" da obra e passar o enredo do século XVII ao seu momento contemporâneo; ou seja, os anos 1970. Ao seu modo, Handke subverteu a escrita de Goethe e deu uma roupagem moderna ao filme. Ainda segundo Gonçalo, nessas mediações, o sonho de realização pessoal de Wilhem não é mais se tornar ator ou um homem de teatro, como primeiro nos narrou Goethe, mas se transformar em um escritor peculiar. Wilhelm tampouco faz uma trajetória pela Alemanha a cavalo ou de carruagem, em vez disso, no filme, anda de bicicleta, trem, carro e, deambulante, também passeia a pé entre paisagens ermas e figuras urbanas industriais. Esse filme revela também um trânsito intermidiático entre Bildungsroman e road movies, entre a escrita e o cinema, entre as paisagens e o teatro de Goethe - rastros intermidiáticos que são compreendidos e potencializados pelas filmagens de Wenders.

Nesse passeio entre a literatura e o cinema, essas seriam algumas cenas que nos ajudam a resumir um filme intimista, contemplativo, que, ao seu modo, descreve com imagens compostas de uma maneira quase que pictórica, a angústia de uma personagem errática, insatisfeita, cheia de dúvidas e anseios, que chancela a linguagem de um cinema europeu que se pronuncia pelo vagar das imagens, com movimentos mínimos, mas carregados da brutalidade de "um real" na figura de um personagem que busca pela sua escrita, repleto de indagações que o faz percorrer alguns momentos de uma história que se quer esquecer (nazismo) até um certo momento atual (década de 70). No transcorrer do filme, percebemos aonde Wim Wenders pretende chegar com esse "movimento em falso". O seu personagem Wilhelm, apesar de ser um viajante, é um homem que olha para dentro. Por meio desse road movie intimista e contemplativo, ele nos ajuda a analisar a identidade cultural de uma Alemanha ressentida pelo nazismo, 
que ainda não sabe bem como lidar com esses reflexos comportamentais do pós-guerra. Ao longo das análises do filme, percebemos algumas incongruências. Por meio dos diálogos e gestos dos personagens, constatamos que por mais que se tenha uma total liberdade comportamental e sexual, as pessoas mal conseguem ser verdadeiras e dialogar. No entanto, assim como o personagem Wilhelm, se encontram encarceradas nos seu próprios medos e neuroses vindas de um mundo em que impera a solidão, a competividade, a incomunicabilidade e o individualismo que, por ora, passa a ser denominado pós-moderno.

Neste capítulo, veremos o quanto um road movie pode se aproximar da literatura. Por meio de movimentos de câmera lentos, enquadramentos fechados, monólogos interiores, diálogos mais densos e um som diegético perturbador, vamos acompanhar o deambular de Wilhelm. São estas as particularidades que nos incitam a percorrer esse segundo road movie de Wim Wenders. Pretendemos demonstrar as marcas discursivas de um gênero cinematógráfico que vão surgindo, ao longo do caminho, e reforçam a identidade de uma cultura, a incomunicabilidade de um escritor, reforçada por um cinema contemplativo, que se afirma na tentativa do ato de escrever, sentir, dialogar, amar, se relacionar, viajar.

O sociólogo Zygmunt Bauman descreveu, em um depoimento gravado em vídeo, uma história corriqueira que, a seu ver, foi responsável por deflagar aquilo que chamou de revolução pós-moderna. Segundo ele, "a culpa" de tudo que estamos vivendo nessa total falta de intimidade é de uma certa moça chamada Vivienne.

Ehrenberg afirmou que, em sua opinião, a revolução pós-moderna começou numa quarta-feira à noite, em um outono da década de 1980, quando uma certa Vivienne, uma mulher comum, na presença de 6 milhões de telespectadores, declarou nunca ter tido um orgasmo durante seu casamento, porque seu marido, Michel, sofre de ejaculação precoce. Eis aí o começo da revolução pós-moderna. Por que o começo da revolução? Porque, repentinamente, na Ágora, as pessoas começaram a confessar coisas que eram a personificação da privacidade, a personificação da intimidade, coisas que você somente contaria, se você for católico, ao padre, no confessionário, ou aos amigos muito chegados ou realmente muito íntimos. Mas você não iria à praça pública anunciar para todos. Então, a Ágora foi conquistada, não pelos regimes totalitários, mas exatamente pela privacidade, por coisas que anteriormente eram privadas. No confessionário, que é a personificação, a encarnação da intimidade e da privacidade, você conversa diretamente com Deus. É um segredo absoluto. Ninguém pode saber o que você confessou no confessionário. Nós instalamos microfones nos confessionários (BAUMAN, 2015. Entrevista em vídeo para o Fronteiras do Pensamento). 
Essa falta de intimidade aliada ao excesso de exposição, também perpassa as idiossincrasias de Wenders quando (re)cria uma personagem errante que permanece, muitas vezes, em silêncio ao longo das suas peregrinações, mas que olha, observa tudo, ao longe, por não querer e não ter intimidade com as pessoas que conhece pelo caminho. Conforme analisou o historiador e sociólogo Sennet (1999), em seu livro que nos dá a noção de intimidade e espaço urbano do século XVIII , em "público", a pessoa observava, expressava-se, em termos daquilo que ela deveria pensar, aprovar, não como resultado de uma interação contínua, mas após um período de atenção passiva, silenciosa, concentrada. Por contraste, o "privado" significava um mundo onde a pessoa poderia se expressar diretamente, assim como seria tocada por outra pessoa; o privado significava um mundo onde reinava a interação, mas que precisava ser secreto. Após esse flashback, podemos dizer que é exatamente desse modo que a personagem de Wilhelm interage com aqueles que se tornaram, por uma causalidade, uma espécie de amigos. Quando passeiam pelas ruas, por mais que estejam em silêncio, algumas trocas de olhares revelam que há uma cumplicidade entre eles. Já no interior de um quarto de hotel, apesar de estarem juntos, cada um dos personagens em ações individualizadas constrói o seu espaço íntimo que pode ser permitido ou não, que o outro invada. Isso pode ser comprovado em uma determinada cena em que "o escritor" tenta dedilhar em sua máquina de escrever um pouco da sua vivência cotidiana, "a atriz" passa uma roupa enquanto reclama da falta de atenção que sente dele em relação a ela, e "o ex-atleta olímpico" e a "contorcionista de circo" assistem, em silêncio, uma besteira qualquer que passa na televisão.

Em plena década de 70, Wenders filma uma história que reforça aquilo que chamamos hoje de "modernidade líquida". Bauman foi categórico ao dizer que a modernidade líquida em que vivemos traz consigo uma misteriosa fragilidade dos laços humanos - um amor líquido. A insegurança inspirada por essa condição estimula desejos conflitantes de estreitar esses laços e ao mesmo tempo mantê-los frouxos. 


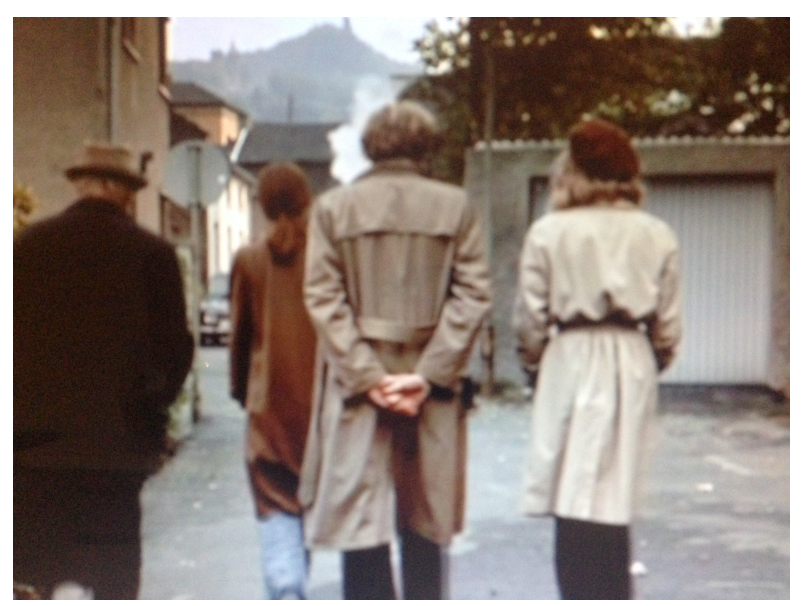

Figura 19: As personagens vagueiam pela cidade

Nas lentes de Wim Wenders, vemos o foco de um mundo repleto de sinais confusos, propensos a mudar com rapidez e de forma imprevisível. No filme, por exemplo, a amorosidade entre os personagens principais (Wilhelm e Therese) se torna uma centelha que não se concretiza. Tudo que é dito fica apenas no âmbito da racionalidade e passa ao largo pela emoção. A incomunicação é total. Por mais que se diga o que se sente, o outro só capta aquilo que ele julga essencial. Isso é fatal para nossa capacidade de amar, seja esse amor direcionado ao próximo, a nosso parceiro ou a nós mesmos.

Tudo que foi e ainda é estudado pelo sociólogo tcheco, em relação ao amor, podemos extrair de algumas cenas do relacionamento conflituoso entre Wilhelm e Therese. Por mais que ela tente ser próxima, íntima dele, há uma barreira invisível que não os deixa se aproximarem. Esse tipo de relação neurótica, cheia de mal-estar é o exemplo de algo fluido que não consegue se solidificar. Conforme observou Bauman, em nosso mundo de furiosa "individualização", onde tudo é "descartável" ou pode ser "precificado", os relacionamentos são bençãos ambíguas. Oscilam entre o sonho e o pesadelo, e não há como determinar quando um se transforma no outro.

Sem humildade e coragem não há amor. Essas duas qualidades são exigidas, em escalas enormes e contínuas, quando se ingressa em uma terra inexplorada e não mapeada. E é a esse território que o amor conduz ao se instalar entre dois ou mais seres humanos.O problema é que todo amor empenha-se em subjugar, mas quando triunfa encontra a derradeira derrota. Todo amor luta para enterrar as fontes de sua precariedade e incerteza, mas, se obtém êxito, logo começa a se enfraquecer - e definhar. O amor 
pode ser, e frequentemente é, tão atemorizante quanto a morte. Só que ele descobre essa verdade com a comoção do desejo e do excitamento. Faz sentido pensar na diferença entre amor e morte como na que existe entre atração e repulsa. Se o desejo quer consumir, o amor quer possuir. Enquanto a realização do desejo coincide com a aniquilação de seu objeto, o amor cresce com a aquisição deste e se realiza na sua durabilidade. Se o desejo se autodestrói, o amor se autoperpetua. O fracasso no relacionamento é muito frequentemente um fracasso na comunicação. A personagem Therese, por exemplo, em uma conversa com Wilhelm diz: “ - Você desconhece tantas coisas. Eu gosto disso em você." Ele, no entanto, permanece mudo, com os braços cruzados, ouvindo o que ela continua a dizer: "acho que caso contrário, você nem conseguiria a escrever. O que eu não gosto é que que quem se surpreende é sempre você. Confie a todos o seu estado." Mais uma vez, ele não esboça nenhum tipo de reação. Continua mudo, impassível, com os dedos próximos da boca, um olhar baixo e pensativo. Por mais que ela tente, a comunicação entre eles é muito difícil de se estabelecer.

No filme, Wenders nos mostra, na década de 70, como vivia um possível escritor encimesmado, preso em seu mundo, com muita dificuldade de se comunicar, de estabelecer relações. Hoje em dia, o advento da proximidade virtual torna as conexões humanas simultaneamente mais frequentes e mais banais, mais intensas e mais breves. As conexões tendem a ser demasiadamente breves e banais para poderem condensar-se em laços. Estar conectado é menos custoso do que "estar engajado" - mas também consideravelmente menos produtivo em termos de construção e manutenção de vínculos. Não admira que a proximidade virtual tenha ganhado a preferência e seja praticada com maior zelo e espontaneidade do que qualquer outra forma de contiguidade. A solidão por trás da porta fechada de um quarto com um telefone celular à mão pode parecer uma condição menos arriscada e mais segura do que compartilhar o terreno doméstico comum. Bauman definiu que um "relacionamento puro" tende a ser, nos dias de hoje, a forma predominante do convívio humano, na qual se entra "pelo que cada um pode ganhar" e se continua apenas enquanto ambas as partes imaginem que estão proporcionando, a cada uma, satisfações suficientes para permanecerem na relação. O compromisso com outra pessoa ou com outras pessoas, em particular o compromisso incondicional e certamente aquele do tipo "até que a morte nos separe", 
na alegria e na tristeza, na riqueza ou na pobreza, parece, cada vez mais, uma armadilha que se deve e se quer evitar a todo custo.

O mundo de hoje parece que está conspirando contra a confiança. Naquele mesmo depoimento já mencionado anteriormente, Bauman (2015) nos fala sobre a ilusão que muitas pessoas ainda vivem em relação à amizade e ao falso convívio coletivo:

\begin{abstract}
Um viciado do Facebook me segredou, não segredou, de fato, mas gabou-se para mim de que havia feito 500 amigos em um dia. Minha resposta foi que eu tenho 86 anos, mas não tenho 500 amigos. Eu não consegui isso. Então, provavelmente, quando ele diz "amigo" e eu digo "amigo", não queremos dizer a mesma coisa. São coisas diferentes. Quando eu era jovem, eu nunca tive o conceito de "redes". Eu tinha o conceito de laços humanos, de comunidades, esse tipo de coisa, mas não redes. Qual é a diferença entre comunidade e rede? A comunidade precede você. Você nasce numa comunidade. Por outro lado, temos a rede. O que é uma rede? Ao contrário da comunidade, a rede é feita e mantida viva por duas atividades diferentes. Uma é conectar e a outra é desconectar.
\end{abstract}

Essa é a vivência do personagem Wilhelm. Um errante que sai de casa em busca de inspiração e liberdade para exercer o seu ofício de escritor. Mas, apesar de se sentir livre, não consegue se destravar das amarras que o cerca - ou não consegue justamente criar laços, se conectar. A sua escrita não flui diante das cobranças de uma mulher que ele acaba de conhecer, mas que deseja, a todo custo, ter uma intimidade, se relacionar com ele. No início do filme, vimos a figura da mãe (castradora) que em um rompante lhe dá uma passagem de trem e pede que ele vá embora e tente, de alguma forma, exercer o seu ofício inútil de escritor. Para ela, de nada adianta ele viver ali trancafiado, mudo, sem conseguir se expressar de nenhum jeito. De uma maneira irônica, mas precisa ela diz: “ Não. Você não precisa dizer nada, querido Wilhelm. Espere até você não aguentar mais. Não perca o seu sentimento de mal-estar e mau humor. Você precisará deles se quiser escrever." Na casa da mãe, Wilhelm era um nada, praticamente sem amigos, com o refúgio da música e dos livros, além de ter a janela do quarto como um único meio de contemplação, uma espécie de válvula de escape. O filme se passa na década de 70, mas, se fosse hoje, não seria improvável de se imaginar a personagem em uma busca solitária, pela internet, na tentativa de fazer amigos ou, quem sabe, se relacionar de longe. No entanto, naquela época, ele não tinha mesmo muitas alternativas. Ouvir música, escrever, perambular pela cidade e viajar era o que lhe 
restava. Tudo isso na tentativa de buscar sentido para uma vida solitária e enfadonha, repleta de crises pessoais.

O cinema de Wim Wenders é um dos refluxos desses "fantasmas" que compõe o imaginário do Novo Cinema Alemão. ${ }^{41}$ Ele é a representação de uma identidade em crise com a "herança" de seu passado recente, de uma temática constante da busca de sentido para o homem e o coletivo, ou melhor, da busca de um novo (outro) sentido. Esse é o recorte estético-temático do filme Movimento em Falso (Falsche Bewegung, 1975). Nesse movimento em que o filme e o seu diretor (Wim Wenders) se situam, consagra a volta dos filmes alemães no mercado mundial. O grande sucesso do Novo Cinema Alemão veio a ser comemorado anos mais tarde por outros cineastas. Em 1966 em Veneza, Alexander Kluge foi premiado com um Leão de Ouro pelo filme Abschied von Gestern (Despedida de Ontem, 1965/1966). Após quatro décadas de abstinência, Rainer Werner Fassbinder, Werner Herzog, Wim Wenders e Volker Schlöndorff cuidaram para que a Alemanha voltasse novamente ao cenário mundial do cinema.

O filme Movimento em Falso que compõe a segunda parte de uma trilogia de road movies, tem como questão central a formação/aprendizagem das identidades, coletivas e individuais, através do deslocamento sobre um espaço culturalmente reconhecido que perdeu seu sentido de ser, histórico e político, demandando uma nova ressignificação. Conforme analisou Menine Jr (2009), ao se retomar o princípio da identidade heideggeriano, realizando uma analogia à leitura crítica do filme, descobre-se que, quando na unidade do ente impera o vazio, a união é impraticável. Um mais um deve ser dois. As relações só se estabelecem por meio da soma. No entanto, o protagonista Wilhelm é um símbolo do individualismo, que aprenderá sobre as experiências vivenciadas com o coletivo, mas pouco transformará sua essência, permanecendo o vazio, o sentimento de perda expressado nas palavras que encerram o filme:

\footnotetext{
${ }^{41}$ Nesse movimento, formado por 26 cineastas, entre os quais Fassbinder, Herzog, o próprio Wenders e Schlöndorff, os filmes deveriam ser novamente autênticos, contar histórias que tratassem de pessoas "reais" das ruas, como também deveriam ser filmados em locações originais. O grande exemplo era a Nouvelle Vague, que tinha revolucionado o cinema francês pouco antes. Mais informações também estão Informações disponíveis no link: http://www.dw.com/pt/novo-cinema-alem\%C3\%A3o-comemora-50anos/a-15787565, acessado em 20/03/2012.
} 
Na realidade, eu ansiava por estar só, para que ninguém me importunasse em minha apatia. Fui a Zugspitze e esperei um acontecimento como um milagre. Por que fugi? Por que ameacei o velho, em vez de ouvir suas narrativas? É como se eu tivesse perdido algo, é como se eu estivesse sempre perdendo algo - em cada novo movimento.

Wilhelm vive uma sucessão de movimentos frustrados: o desejo sexual não se realiza com Therese (Hanna Schygulla), e vice-versa; a "herança" maldita do passado de Laertes (nazismo) ainda é uma questão em aberto (Hans Christian Blech); o poema medíocre de Landau (Peter Kern) não comunica; a jovem Mignon (Nastassja Kinski) continua errante, marginal, etc. O filme é o um mero retrato de uma situação identificada pelos encontros e desencontros, de uma viagem interior em que nada se aprende e o que permanece é a frustração e o vazio; uma dura iniciação tanto para o protagonista, quanto para o grupo de pessoas que ele se envolve.

Desde o início, os laços que se estabelecem entre os personagens são frágeis, assim como se formaram quase que espontaneamente, podem dissolver-se a qualquer momento. É a sensação que impera na Alemanha, um mal-estar social generalizado. As experiências vividas coletivamente por eles apenas reforçam o espanto de existir, perambular ou compartilhar o tédio em frente à televisão. Tudo indica uma profunda apatia que só condena a possibilidade de se formar um grupo coeso. Essa sensação de solidão, melancolia e sufocamento nos faz lembrar os quadros de Edward Hopper (1882 - 1967). Por sinal, conforme já mencionamos, um dos pintores prediletos de Wim Wenders. Edward Hopper é o pintor do espaço, da solidão e da luz, da luz solar quando é dia ou da luz elétrica quando é de noite. O ponto de partida para essa luz são as vidraças que definem cenas poéticas, onde a solidão é um elemento constante. Esta maestria de saber utilizar a iluminação para contar histórias, faz com que muitas vezes relacionamos o pintor com o cinema e subscreve as ideias de Bazin que o cinema herdou da pintura o desejo de refletir a realidade. Os espaços urbanos servem para representar o vazio existencial, o que implica que pode haver uma história por trás de cada pintura. Hopper dá destaque aos objetos inanimados: os trilhos dos trens, estações, edifícios da cidade de Nova York. Em contrapartida, os personagens parecem estar absortos, bloqueados, ensimesmados, incapazes de entrarem em contato com o outro, capturam a alienação dos seres humanos no mundo moderno. Precisamente, essa habilidade da perspectiva vital é saber como utilizar uma pintura narrativa capaz de contar histórias. Isso que Hopper fez, e mantém até hoje, uma influência inegável sobre 
o cinema, que, por sua vez, mantém uma influência recíproca sobre o artista. Não por acaso, o pintor norte-americano foi mencionado, várias vezes, como uma referência para cineastas pela sua temática, enquadramento e uso da luz.

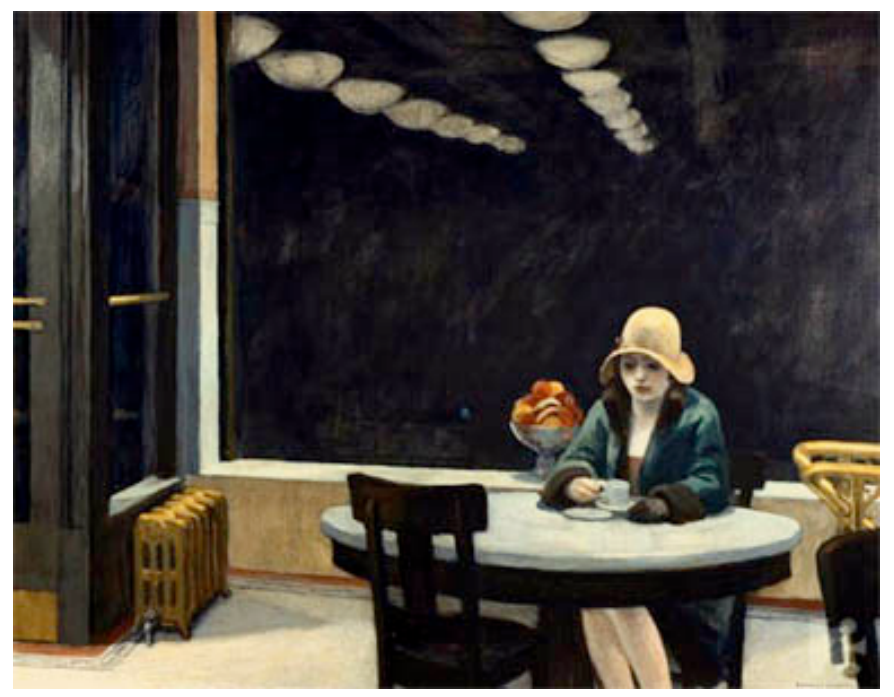

Figura 20: Automat (1927) - alienação e isolamento no quadro de Edward Hopper

Foi ele que mais entendeu a melancolia do homem moderno. Seus quadros, em sua grande maioria, retratam pessoas solitárias em seus quartos ou em espaços urbanos, quase todas com uma certa curvatura no pescoço que os empurra para baixo ou em uma posição de completa contrição, próxima da posição fetal onde o mundo parece uma ameaça detentora de um vazio imenso que não pode ser preenchido. No quadro acima, a mulher se encontra, com uma xícara de café nas mãos, em um restaurante absolutamente vazio. Essa sensação de solidão presente na maioria dos quadros de Edward Hopper, fez a pintura dele ser associada com a alienação urbana.

Wenders, em seus filmes, retrata por meio das suas personagens principais um profundo estado de descontentamento, de uma busca solitária e desenfreada por algo ou alguém. Seus personagens, são, quase sempre, viajantes solitários que percorrem estradas, cafés, aeroportos, postos de gasolina. Vale lembrarmos do Philip Winter (Alice nas Cidades, 1974) nas cenas iniciais do filme, sentado na areia, debaixo de um pontão, absolutamente solitário, de frente para o mar. Lembramos, também, do personagem Wilhelm (Movimento Em Falso, 1975) que em sua viagem solitário de trem, descortina o mundo com um olhar absorto e contemplativo, diante da janela. O personagem Bruno 
Winter (No Decurso do Tempo, 1976) também reflete um pouco dessa mistura de melancolia e solidão quando se depara com alguns cinemas abandonados pelo interior da Alemanha. Sabemos que a melancolia é um dos elementos essenciais para a arte. Como diria Cazuza, para os criadores, é uma tentativa diária de transformar o tédio em melodia. É o tempo necessário para contemplar o mundo, para refletir sobre o cotidiano, um sentimento de ausência e vazio, quase uma morte, uma sensação de perda de algo muito importante que falta em nossas vidas, mas que não sabemos dizer exatamente o que é.

De certo modo, a paisagem nos filmes de Wim Wenders refletem isso. Segundo Karina Dias (2010), a experiência da paisagem no cotidiano se forja, então, na junção entre uma certa maneira de olhar e os caminhos percorridos. Ela tomaria forma a partir de detalhes corriqueiros que, por serem vistos e (re)vistos continuamente, se tornariam in-visíveis aos nossos olhos. No entanto, a partir de um movimento do olhar que se configura como um atravessamento do mundo, ela nos revela novas percepções espaciais, uma espécie de elo singular que nos entrelaça aos lugares que nos interpelam. Para Wenders (1994), uma rua ou a fachada de uma casa, uma montanha ou uma ponte ou um rio ou o que quer que seja, são paisagens que possuem uma história, uma "personalidade", uma identidade que deve ser levada a sério. Ainda segundo Dias (2010), a paisagem deriva de um enquadramento do olhar, alia o lado objetivo e concreto do mundo à subjetividade do observador que a contempla. E assim ela se torna uma experiência sensível do espaço. Um mundo concebido a partir daquilo que vemos. De acordo com Merleau-Ponty, "o mundo é aquilo que vemos [...] mas se perguntarmos o que é nós, o que é ver e o que é a coisa ou o mundo, entramos em um labirinto de dificuldades e contradições." A distância do ato de olhar é fundamental para compreendermos a paisagem. Nos dias de hoje, nosso cotidiano é povoado por toda forma de excesso, visual ou sonoro; ele é barulhento e animado e a percepção de uma paisagem não é nada evidente. Não é fácil encontrar a distância que nos fará ver, ver de outra maneira, ver o espaço-em-paisagem. Uma paisagem que não se comporia apenas do que vemos, mas do que ouvimos, sentimos, pressentimos (DIAS, 2010).

Esse é um retrato da paisagem vivenciada por Wilhelm nos seus deslocamentos. Quando anda de bicicleta, à pé ou, simplesmente, observa pelas janelas do trem ou dos lugares onde dorme, tudo o que vê, tudo o que contempla é aquilo que o seu corpo 
cansado e melancólico pressente: uma Alemanha inerte, distante, falsamente silenciosa, sombria e fria. Tudo que se descortina, vagarosamente, à sua frente, são não lugares que os seus olhos, de algum modo, tentam decodificar. Ruelas, becos, postos de gasolina, cafés, estações de trem, prédios habitados por pessoas solitárias. Em uma das cenas, enquanto Wilhelm anda pela cidade na companhia de seus mais novos conhecidos, um homem grita diante da janela o quanto é difícil ter que conviver com o ruído de um planador dentro da cabeça. Isso, talvez, simbolize as neuroses de um povo que sobreviveu a uma guerra e, mesmo na mais completa solidão, ouve sons ou vozes imaginárias, cheias de violências simbólicas que, por mais que se esteja solitário, com tantas obsessões, fica impossível se sentir sozinho. O silêncio, por mais que seja buscado, não é possível de ser atingido, nem mesmo durante à noite, enquanto ele tenta dormir.

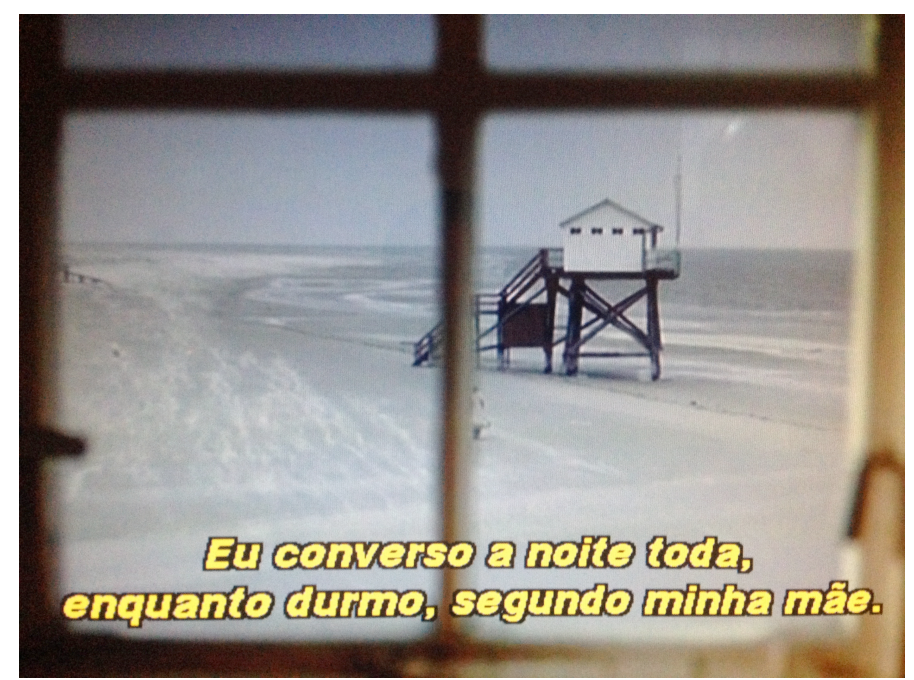

Figura 21: Plano do filme Movimento Em Falso que reflete o pensamento de Wilhelm e a sua inquietude.

A paisagem, segundo Augustin Berque, não reside apenas, nem somente, no objeto e nem apenas no sujeito, mas na interação complexa entre os dois. Nos filmes de Wim Wenders, e o Movimento Em Falso não foge à regra, a relação das personagens com a janela merece uma atenção especial. Seja pela janela do carro, do trem, do avião ou dos apartamentos em que elas se encontrem, a janela serve como uma espécie de moldura de um mundo exterior que precisa ser isolado, destacado, para ser apreendido, na tentativa de ser, minimamente, assimilado. Essa janela, ao mesmo tempo que delimita o mundo de fora, delimita, também, um mundo de dentro. Afinal, ela remete ao confinamento de quem olha. Talvez esse "enquadramento" não seja aleatório para um 
diretor de cinema que pensa e elabora os seus quadros imagéticos de maneira pictórica. Conforme Karina Dias descreveu (2010, p.139), o caminho aberto pelos italianos do Trecento com a representação da paisagem ficará estranhamente esquecido para somente ser aprofundado, na segunda metade do século 15, pelos pintores das escolas do Norte. Nas obras flamengas, o elemento decisivo foi o aparecimento da janela, essa abertura no interior da pintura que significou uma janela para o mundo, uma nova abordagem do mundo exterior. Alain Roger evoca o aparecimento da janela como a moldura que isola e enquadra, transformando na pintura, o território em paisagem. Para Raffaelle Milani, a janela é um meio de isolar as partes do mundo envolvente, ampliando assim o seu valor estético. Penetrando a cena da perspectiva tradicional, a janela nos convidaria a percorrer naturalmente a paisagem. $\mathrm{O}$ autor acrescenta que $\mathrm{O}$ enquadramento e a janela implicam a veduta, isto é, uma vista que seria a reprodução de um aspecto da realidade natural.

O filme em questão é pródigo em mostrar essa interação emocional das personagens com as janelas. Por meio delas, percebemos aproximações e distanciamentos, pensamentos e angústias, desejos, irrefreáveis, de deslocamentos por meio de paisagens inexploradas que suscitam um porvir. Através da janela, Wilhelm contempla as paisagens que anseia explorar, percebe imagens um pouco embaçadas, assim como os seus pensamentos. Foi, também, por meio da janela, que ele percebia o mundo que deveria ser explorado fora da janela do seu quarto e, também, quando avistou pela primeira vez Therese. Cada um no seu trem, cada um na sua janela, foi inevitável a troca de olhares. Ele olha através do vidro, ela, por sua vez, com a janela aberta, só faltou se lançar.

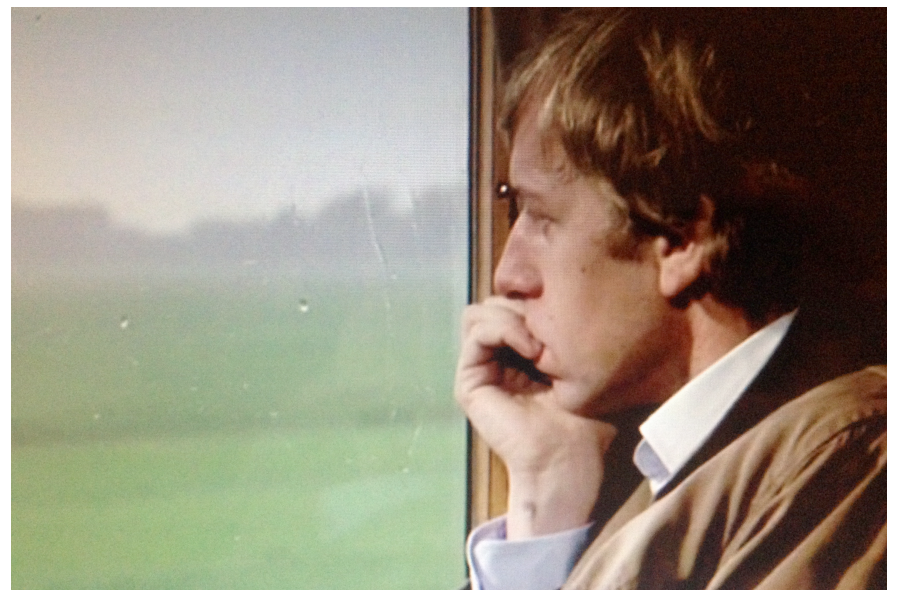

Figura 22: Wilhelm contempla a paisagem e a vida que deixa para trás, diante da janela do trem 


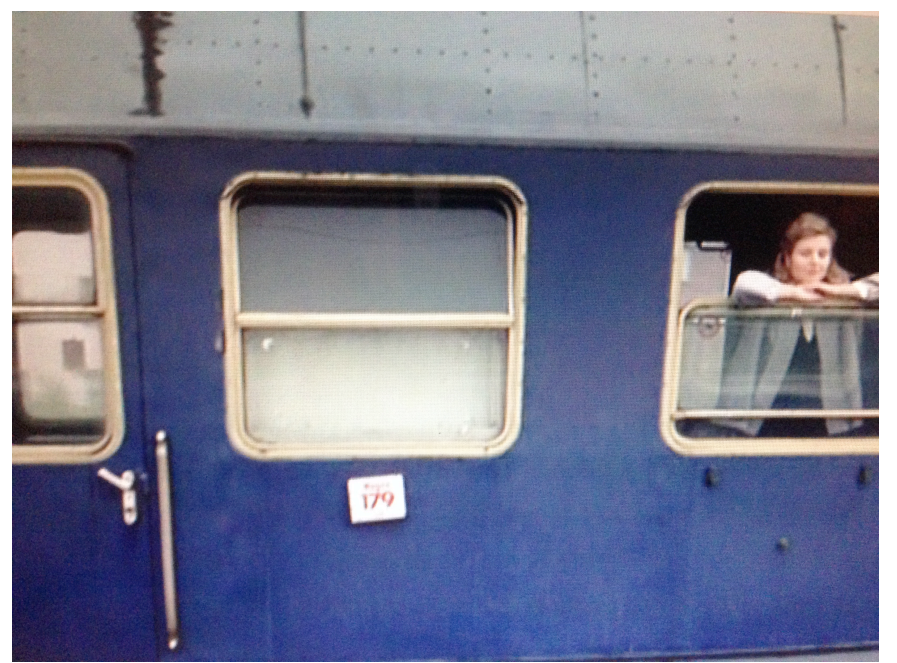

Figura 23: Diante da janela do trem, Therese se encanta por Wilhelm

A janela e a pintura são alguns artifícios utilizados pelo cineasta para representar também a sensação de solidão, vazio e isolamento das personagens. Nos road movies, janelas e pára-brisas de automóveis servem como dispositivos imagéticos para representar a fluidez das coisas, das imagens, das pessoas, daquilo que se deixa para trás. Uma espécie de tela de cinema frágil e envidraçada onde as imagens se projetam, mas, dificilmente, se conseguem evitar o aparecimento dos reflexos, sejam eles reflexos do monólogo interior da personagem que emitem o seu descontentamento ou reflexos de uma estrada desconhecida que precisa ser desvendada.

Na cena final de Movimento em Falso, Wenders refaz a cena presente no quadro O peregrino sobre o mar de nuvens (Wanderer über dem Nebelmeer, 1818), de Caspar David Friedrich. Este quadro é tido como um ícone do indivíduo romântico. Esse espírito romântico passa a designar toda uma visão de mundo centrada no indivíduo. Os autores românticos voltaram-se cada vez mais para si mesmos, retratando o drama humano, amores trágicos, ideais utópicos e desejos, irrefreáveis, de escapismo. Friedrich soube capturar de forma pictórica esse ideal romântico ao enfatizar toda essa grandeza do sublime. Por meio de suas telas questionava a incongruência do contato entre o homem e Deus, instaurando em nós, que nos limitamos a contemplar aquele que contempla, uma sensação de abismo inigualável, equilibrada entre o maravilhar-se e a impotência, a vida e a morte. O poder da paisagem em suas telas é sempre devastador, responsável por convencer o homem de sua pequenez e finitude, identificando através de uma extensão natural vazia um vazio que é inerente ao humano, não em sua 
imensidão, mas como numa destruição. No entanto, muitas das suas obras não centralizam o homem como nesta tela, pelo contrário, o reduzem a um mínimo quase deformador, intensificando a impressão do sublime pelo contraste de grandezas.
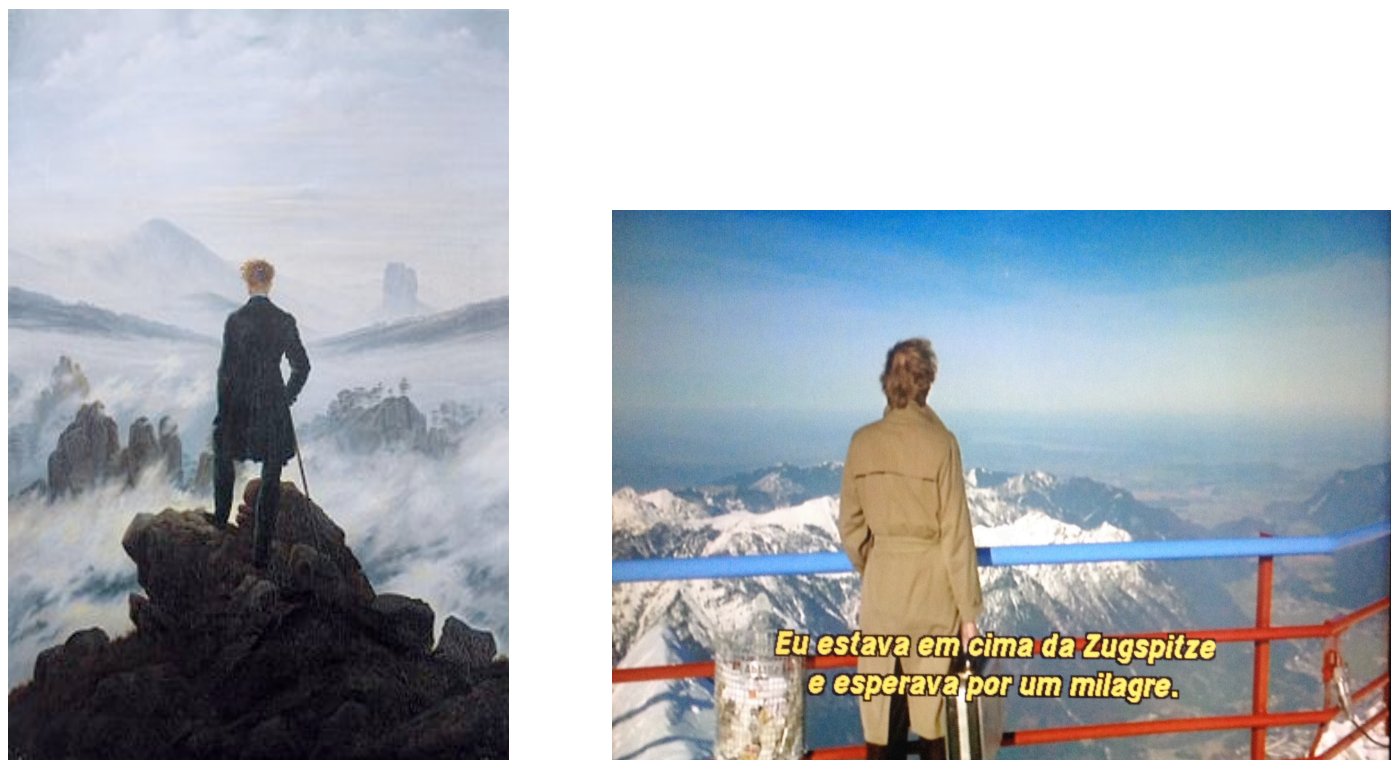

Figura 24: O peregrino no quadro de Friedrich (esq.) e o viajante (Wilhelm) no enquadramento de Wenders (dir.)

Ali está um homem (o peregrino), no alto de um penhasco, que usa um sobretudo verde e segura uma bengala na mão direita. Ele contempla as nuvens, que parecem formar um mar sobre os montes vizinhos. Com uma postura ereta, tem um certo ar calmo e controlado. $\mathrm{O}$ vento bate em seus cabelos loiros enquanto o caminhante observa os picos rochosos que se misturam com a névoa. É possível ver algumas árvores à distância, e as montanhas se misturam com o céu luminoso à medida que ficam mais longe do observador, criando um ar de mistério.

No que tange à composição, o homem está bem no centro da pintura, e as linhas horizontais das montanhas convergem para ele. $\mathrm{O}$ contorno de duas montanhas, à direita e à esquerda do homem, parecem apontar para o seu coração. Há um forte contraste entre as vestes escuras que o homem usa e a claridade do céu e da neblina. 
No filme, Wilhelm Meister se posta no mirante, no topo do Zungspite (o ponto mais alto da Alemanha), com uma capa bege de gabardine, e uma das mãos no bolso, enquanto a outra segura uma pequena maleta. Ele chega, vagarosamente, e coloca a maleta no chão. Com as duas mãos no bolso, sente o vento bater no seu rosto e esvoaçar os seus cabelos loiros. Nós, o vemos de costas. Fica, ali, absorto, protegido por algumas barras de segurança, enquanto contempla, ao longe, a neve sobre os montes. Em menos de 30 segundos, com a câmera inerte tal qual a pintura de Friedrich, o enquadramento de Wenders junto ao monólogo interior do personagem criado por Peter Handke, sintetizam uma beleza "cine-pictórica-literária" sem igual:

Eu disse a Therese que eu queria ficar na Alemanha por conhecer pouco o país, para poder escrever sobre ele. Mas isto só tinha sido um pretexto. $\mathrm{Na}$ verdade, eu só ansiava estar sozinho para poder ser estúpido, sem ser perturbado. Eu estava em cima da Zugspitze e esperava por um milagre. Mas não houve tempestade de neve. Por que eu estava aqui e não com os outros? Por que eu ameacei o velho, ao invés de deixá-lo me contar mais? Pareceu que eu havia perdido algo...E ainda estivesse perdendo com cada movimento novo. $^{42}$

Ao suturar uma imagem do presente com outra do passado (pintura de Friedrich), Wenders causa um estranhamento; uma reflexão crítica que se pergunta a que ponto se chegou com o idealismo, o iluminismo, com toda essa incomunicabilidade entre pessoas que deveriam dialogar, com todo um deambular que nos leva pra dentro de nós mesmos, com a contemplação de paisagens que só refletem a nossa errância, com um narrador pós-moderno de ideais românticos, com as identidades fragmentadas, com o projeto de um país. O final é aberto; o "fantasma", melancólico, permanece. No seu Movimento Em Falso, Wim Wenders reforça a gênese de uma linguagem de cinema que busca o deslocamento para representar uma cultura ocidental com uma identidade por ser descoberta, cheia de dúvidas, mal-estar, fluidez, e toda aquela incomunicabilidade e fragmentação apresentada por Bauman. Embora o filme não seja um clássico "road movie" com os personagens, por todo o tempo, dentro de um carro viajando pelas estradas, conforme o primeiro do gênero (Alice nas Cidades) que inicia essa trilogia, ele nos mostra, por meio das andanças da personagem do Wilhelm, que não há a necessidade da estrada para quem deseja ir, para quem precisa sair, se buscar, se

\footnotetext{
${ }^{42}$ Monólogo interior do personagem Wilhelm Meister dito na tomada final do filme Movimento Em Falso.
} 
deslocar. Embora ela exista, a sensação da busca pelo novo e o inesperado não necessita da viagem. O percurso pode ser intensificado pela sensação de uma busca interior. Ao seu modo, por meio de silêncios e enquadramentos pictóricos, Wenders nos remete a um cinema contemplativo, quase literário, cheios de significados e poesia. Talvez, a grande metáfora de um filme que, assim como a sua personagem e os seus conflitos identitários, nos remete ao trajeto da pintura, da fotografia, da literatura e, principalmente, de um cinema em transição que, ainda hoje, anseia por ser redescoberto. 


\section{A identidade como temática pós-moderna}

Quem somos nós? Por onde vagam as nossas imagens? Qual é a busca do cinema? Nesses tempos de fragmentação, insegurança e incertezas, veremos que é quase impossível ter uma única resposta sobre alguma coisa. Conforme salientado por Bauman (2007), a insegurança do presente e a incerteza do futuro nascem de um sentimento de impotência. Esse sentimento, muitas vezes, é alimentado pela globalização que transforma as cidades em campos de batalha onde poderes globais se chocam com identidades locais. Aquilo que imaginávamos ser nosso, único e exclusivo, trata-se de um espelhamento do mundo. O cultural tem perdido espaço, constantemente, para o global, mundial. Assim como nós, a linguagem do cinema pode não mudar por causa de um medo, medo da utopia de uma mudança, medo de um novo recomeço.

Neste capítulo, a identidade será estudada como uma temática pós-moderna. Ao longo da vida, assumimos identidades diferentes em diferentes momentos. Essas identidades não são unificadas ao redor de um "eu" coerente. Dentro de nós há identidades contraditórias, empurrando em diferentes direções, de tal modo que nossas identificações estão sendo continuamente deslocadas. Muitas vezes, se sentimos que temos uma identidade unificada desde o nascimento até a morte é apenas porque construímos uma cômoda estória sobre nós mesmos ou uma confortadora "narrativa do eu" (HALL, 1997, p. 14).

No final da década de 1920, Sigmund Freud já vaticinou sobre isso em seu $O$ Mal-Estar na Civilização. Esse medo pode ser quebrado. Nós, seres humanos, precisamos nos organizar em sociedade para nos defender da nossa própria natureza que nos agride. De acordo com ele, um certo sentimento de "religiosidade" poderia nos ajudar: uma sensação de eternidade, de algo ilimitado, sem fronteiras - "oceânico", por assim dizer. Ele também poderia estar falando sobre a linguagem do cinema, pois o argumento do Freud tornou-se argumentos de vários filmes como, por exemplo, esses do Wenders que analisamos por aqui. A arte imita a vida. Todo o mal estar na civilização já foi projetado nas telas: pulsões, frustrações, castração dos instintos básicos, sofrimentos, decepções e sublimações. No entanto, a maneira como esses sentimentos são expressos no cinema, nos ajudará a decodificar essa linguagem na diegese dos filmes. Freud, apesar de escrever há quase um século, ressaltou aquilo que Bauman descreve na contemporaneidade, as nossas pulsões, frustrações, dificuldades de 
estabelecer laços. Todas as suas considerações ainda permanecem válidas no nosso contexto pois os conflitos que alimentam as narrativas do cinema ainda são os mesmos.

No seu estudo sobre as cidades, Sennet (1999) comenta que os processos de individualização fazem com que os espaços públicos e de convivência percam a importância de outrora. Essa hipótese de Sennet aproxima-se dos personagens de Wenders já que todos eles partem em um ambiente externo para reatarem os laços com outras pessoas. Com o passar do tempo, as relações sociais vêm mudando. As linguagens visuais acompanham e, por vezes, questionam essas mudanças.

Para nos ajudar a entender alguns fenômenos de uma identidade em transformação, analisaremos algumas cenas do filme No decurso do tempo (1976). Por meio de uma história de amizade entre um técnico de projetores de cinema e um pediatra recém separado, que viajam juntos pela Alemanha Oriental, buscaremos respostas para a identidade de um cinema que nos ajuda a refletir a nossa própria identidade. Buscaremos confrontar essa multiplicidade desconcertante e cambiante de identidades possíveis, e a partir delas, tentar nos identificar.

Por aqui, o cinema será um norte entre o próprio questionamento da linguagem, os possíveis caminhos e descaminhos que ele poderá trilhar, além de servir como elo para um resgate da própria identidade de um cinema em constante transformação. Filmes, muitas vezes, vêm carregados de histórias. A narrativa ficcional traz conflitos enredados em um tempo fílmico remoto que nos ajuda a repensar e entender quem somos nós e como experimentamos os nossos possíveis papéis sociais. Os filmes de Wim Wenders questionam, o tempo todo, não apenas o nosso modo de vida, mas a maneira como vivemos em um mundo cada vez mais acelerado e "líquido", onde impera o narcisismo e a individualidade, com uma comunicação cheia de ruídos e, muitas vezes, invasiva ou indiferente, que reflete valores, no mínimo, deturpados.

Diante disso percorremos alguns conceitos analisados por Freud e Sennet que, apesar de tratarem de temas tão diferentes, de alguma maneira podem ser correlacionados. Freud por ter pensado o quanto somos infelizes por viver em sociedade, já Sennet distingue o modo como nos comportamos em espaços públicos e privados. Com certeza, aquilo que evidenciamos por aqui é o que Wenders tenta nos mostrar por meio de imagens poéticas, sutis, mas repletas de significados. 
Todos os seus personagens parecem vagar de maneira errática por estradas, cidades e países na busca de respostas para seus conflitos interiores, ou, ainda, na possibilidade de estabelecerem diálogos com pessoas, aparentemente, estranhas, mas que, no fundo, vivem uma série de conflitos bem semelhantes. Alguns amam, mas não se sentem amados, outros têm uma família, mas não conseguem interagir de maneira acolhedora e pacífica entre os seus, muitos trabalham, mas também não se sentem satisfeitos ou recompensados por aquilo que fazem. De certo modo, dividem uma certa angústia por não saberem como estabelecer vínculos e, mais ainda, se esses vínculos têm chances de vingarem nesse mundo onde há falta de crédito nas relações e prosperam as egolatrias. Em No Decurso do Tempo, Wenders reforça essas dificuldades. Os personagens principais (Bruno e Robert) estavam sozinhos antes de se encontrarem, cada um com a sua história, cada um com o seu passado. Mas ao longo do percurso, mesmo em silêncio, uma frágil amizade se estabelece. No entanto, na vida de cada um, existe um peso muito grande de algumas histórias inacabadas. Talvez, esse seja o maior problema para que essa amizade se fortaleça.

Segundo Sennet, as ideias modernas a respeito da psicologia dessa vida privada são confusas. Poucas pessoas afirmariam atualmente que suas vidas psíquicas surgem por geração espontânea, independentes de condições sociais e de influências ambientais. $\mathrm{O}$ eu de cada pessoa tornou-se o seu próprio fardo. Conhecer-se a si mesmo tornou-se antes uma finalidade do que um meio através do qual se conhece o mundo. No entanto, multidões de pessoas estão agora preocupadas, mais do que nunca, apenas com as histórias de suas próprias vidas e com suas emoções particulares. Neste exato momento, bilhões de pessoas estão conectadas aos seus computadores dizendo ao mundo o que estão pensando, o que comeram, aonde foram, forjando uma falsa intimidade. Sabemos que intimidade conota calor, confiança e expressão aberta de sentimentos. Diante disso, nos surge a pergunta: será que estamos conseguindo vivenciar essa intimidade em tempos tão artificiais? O mundo exterior, o mundo impessoal, parece nos decepcionar, parece rançoso e vazio. As sociedades ocidentais estão mudando a partir de algo semelhante a um estado voltado para o outro, para um tipo voltado para a interioridade com a ressalva de que, em meio à preocupação consigo mesmo, ninguém pode dizer o que há dentro. Como resultado, originou-se uma certa esquizofrenia, uma confusão entre a vida pública e a vida íntima. A televisão aberta está recheada de programas 
inúteis que fazem qualquer coisa para hipnotizar uma audiência incauta. A espetacularização do grotesco veio à tona com os reality shows (Big Brother e afins) e as revistas de fofoca que trouxeram uma intimidade forjada tida, facilmente, como pública, mas de uma maneira pra lá de superficial.

Vivemos um tempo de total ansiedade. No entanto, a ansiedade diante daquilo que se sente também poderia ser considerada como a difusão e a vulgarização da "busca da personalidade" romântica. Os personagens de Wim Wenders estão imbuídos nessa personalidade. São viajantes errantes e solitários que buscam algo ou alguém para se locupletar. Philip Winter (Alice nas Cidades) se entregava às imagens fotográficas instantâneas que, mesmo vazias de sentidos (mudas, como dizia), diziam mais coisas do que quaisquer sons ou palavras, Wilhelm Meister (Movimento Em Falso), no seu deambular ensimesmado, recorria ao texto, à busca inefável pelo universo das palavras, àquelas que foram traçadas por Goethe, já Bruno Winter (No Decurso do Tempo) se entrega ao cinema, à força das imagens carregadas de história que o ajudam a construir a sua própria narrativa.

\section{O espaço público destina-se à passagem, não à permanência}

Sennet nos diz, ainda, que a idéia do espaço público como derivação do movimento corresponde exatamente às relações entre espaço e movimento produzidos pelo automóvel particular. O carro dá liberdade de movimentos; pode-se viajar sem ser interrompido por paradas obrigatórias, como as do metrô, sem mudar a sua forma de movimento, de ônibus, metrô, via elevada ou a pé, ao ir do lugar A para o lugar B. As ruas da cidade adquirem então uma função peculiar: permitir a movimentação. A tecnologia da movimentação moderna substitui o fato de estar na rua por um desejo de eliminar as coerções da geografia. Nos road movies sabemos que o carro tem uma importância fundamental. É ele que ajuda o viajante a explorar geografias, a buscar o contato com o outro, a desbravar novas paisagens. Conforme vimos anteriormente, é por meio do automóvel que os nossos viajantes solitários buscam o rompimento das fronteiras, ao tentarem estabelecer contatos com outras identidades culturais. O automóvel, para esses viajantes, funciona como uma casa, um lugar aonde ele se sente protegido, uma espécie de templo sagrado em só ele pode permitir que o outro - 
estranho - possa adentrar e, quem sabe, comungar do seu silêncio, enquanto aprecia o imenso vazio das paisagens.

Para Sennet, existe, ainda, um terceiro sentido, um sentido um tanto mais brutal de isolamento social em locais públicos, um isolamento produzido diretamente pela nossa visibilidade para os outros. Quando todos estão se vigiando mutuamente, diminui a sociabilidade, e o silêncio é a única forma de proteção. Em outros termos, diríamos: os seres humanos precisam manter uma certa distância da observação íntima por parte do outro para poderem sentir-se sociáveis. Aumentem o contato íntimo e diminuirão a sociabilidade. Esta é a lógica de um tipo de eficiência burocrática que estamos vivendo nesses tempos de intimidade remota e, cada vez mais, virtual.

Esse é um pouco do trajeto que iremos percorrer neste capítulo. Em No Decurso do Tempo, Wim Wenders encerra a sua trilogia de road movies que o consagrou como o cineasta das viagens, do silêncio, dos espaços em trânsito, das paisagens, dos alertas sobre a nossa condição humana em constante transformação, dos personagens em busca das suas identidades. Neste filme, veremos o quanto a caligrafia de um cinema depende da sua história, do seu passado, de um legado. Na vida, assim como nas imagens, tudo se soma para se transformar.

\subsection{No decurso do tempo - Em busca da identidade perdida}

No primeiro plano do filme, a personagem Bruno Winter que, por sinal, é representado pelo mesmo ator (Rudiger Vogler) e tem o mesmo sobrenome do jornalista frustrado (Philip Winter) de Alice Nas Cidades (1974), ajusta uma bobina na bitola de um projetor. Enquanto faz seu trabalho, conversa com um senhor sentado ao fundo da sala de projeção de um antigo cinema. Pela conversa que se segue, percebemos aonde ele quer chegar: 


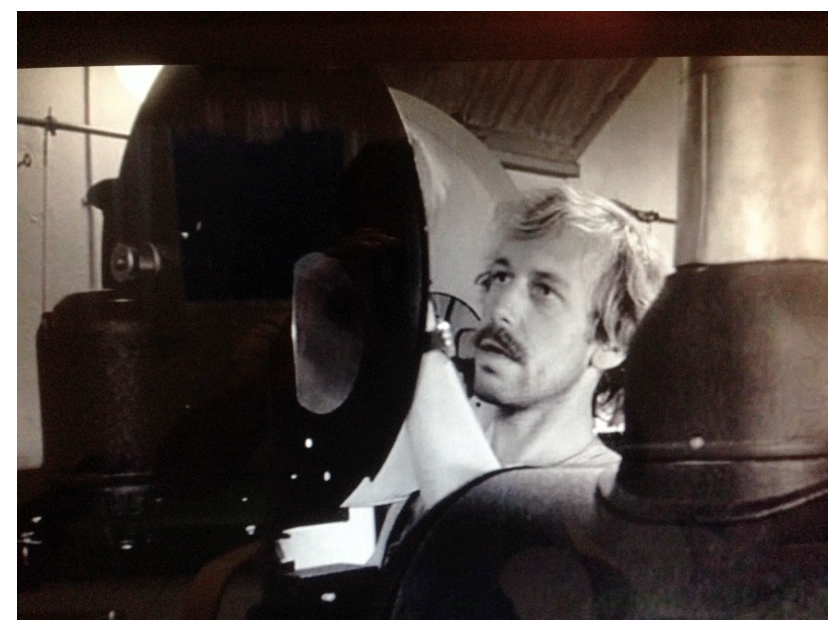

Figura 25: Bruno Winter e o seu trabalho como projecionista

(Bruno) - Você me contou que era compositor musical de cinema na última vez?

(Senhor) - Eu era compositor de cinema sim. Minha mulher tocava piano; eu, violino. Tocávamos juntos. Quando era um filme maior como "Os Nibelungos" ou "Ben-Hur" que exigia outro tipo de música contratávamos um violoncelista, um baixista, um harmonista e eventualmente um baterista. Não era fácil tocar, não é?

(Bruno) - Depois todos vocês ficaram desempregados?

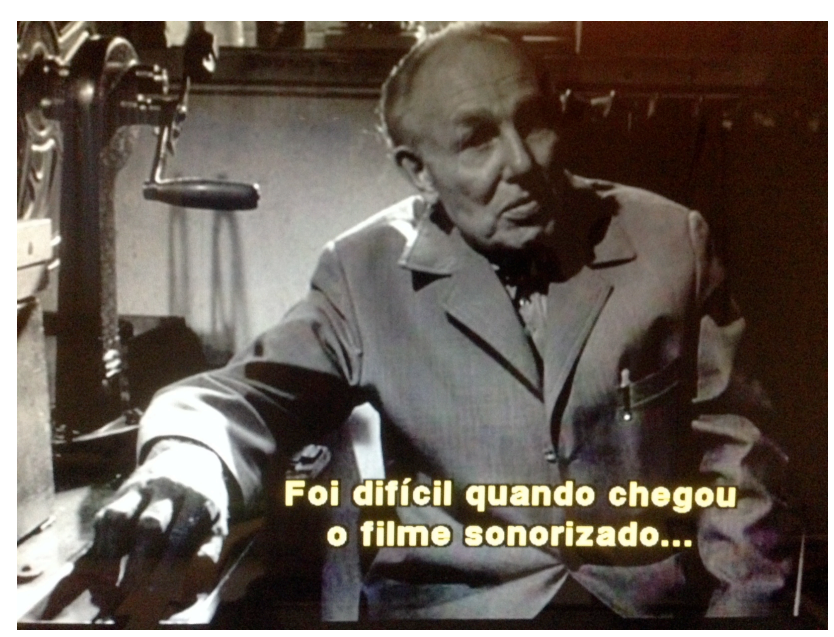

Figura 26: Ao longo da conversa, o nazista e ex-dono de cinema, faz muitas revelações

(Senhor) - Foi difícil quando chegou o filme sonorizado. O filme sonorizado de verdade porque, inicialmente, era apenas o som da vitrola. Havia as grandes chapas e os atos Havia de 12 a 14 atos. Aproximadamente nesses filmes eram atos pequenos e sempre 
algum filme rasgava, e as coisas não faziam mais sentido. Precisava colar o filme à noite, na sala de projeção e, mesmo assim, não dava certo. E, no dia seguinte, nos xingavam. Era assim que funcionava.

(Bruno) - Qual foi a sua maior música?

(Senhor) - A do filme "Os Nibelungos". Eram duas partes: a primeira parte, "A morte de Siegfried", e a segunda, "a vingança de Krimhild". Acho que "Ben-Hur" também tinha duas partes, não lembro bem. "Os Nibelungos" tinha duas partes.

(Bruno) - Se tivesse de viver de cinema, você conseguiria?

(Senhor) - Impossível. Hoje em dia, não.

(Bruno) - Consegue conceber que, em alguns anos, não haverá mais cinema nas pequenas cidades?

(Senhor) - Acredito que existiram cinemas como, por exemplo, os de nossa região: em Schierdingen, Hohenberg, em Heckstadt,... Em Diesberg todas umas cidadezinhas sem graça. Mas hoje eles sumiram. Como ainda existem cinemas, ouso afirmar que em dez anos ainda funcionarão. Enquanto filmes forem produzidos, isso se ainda forem produzidos até lá.

(Bruno) - Antigamente você conseguia viver de cinema?

(Senhor) - Só consegui a partir de 1951. Durante anos, não tive mais direito de mantêlo. Por causa do "Terceiro Reich" e coisas do gênero.

(Bruno) - Por que não teve o direito de trabalhar com ele?

(Senhor) - Porque fui membro do partido SPD, NSPDAP ou como quer que fosse chamado aquele partido. Tive que abrir um processo de 1950 a 1951 para reaver meu cinema. Antigamente, chamava-se "Teatro cinematográfico". 
Após quase cinco minutos de um diálogo tenso e cheio de revelações, eis que surge a trilha incidental que apresenta o título do filme Im Lauf Der Zeit (No decurso do tempo) e os créditos iniciais.

Em seguida, a câmera abre para uma imagem do rio Reno com um barco navegando tranquilamente pelo rio. Ouvimos o som do vento nas folhagens e, não mais que de repente, surge um carro com um forte rastro de fumaça atrás e saí, há mil por hora, cortando o quadro. Enquanto o carro se aproxima, em altíssima velocidade para um fusca, vemos, na direção, um homem de óculos escuros com o braço para fora do carro. O ruído do motor vai ficando cada vez mais alto e próximo. Em um determinado momento, enquanto dirige, o homem olha para uma foto de uma casa, mantém o foco por alguns segundos e a rasga, em pedacinhos, logo em seguida. Um pouco mais a frente, a câmera avista um caminhão de mudança e, dentro dele, está sentado um homem que contempla a vista. Há um corte, novamente, para o fusquinha envenenado que pára em um posto de gasolina, olha para um menino e, com um gesto, oferece carona.

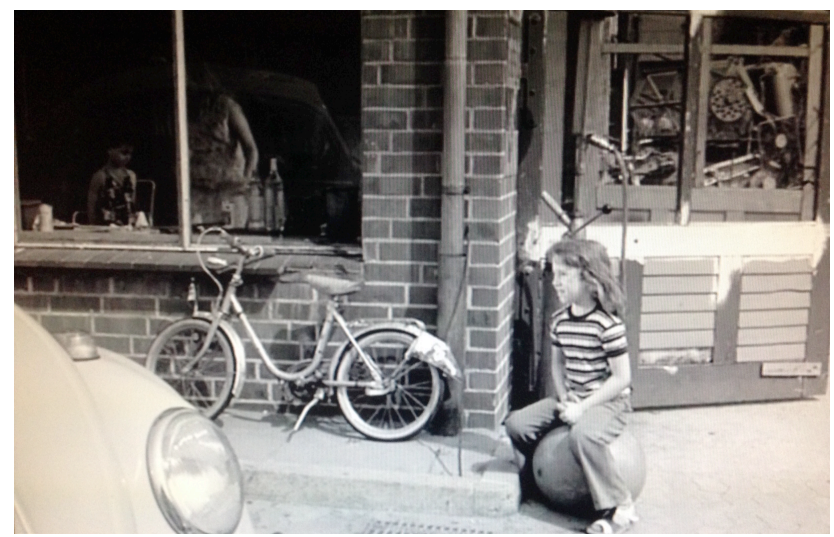

Figura 27: Um fotograma que poderia ser um quadro do Hopper

Embora o plano enfatizado seja o de um menino, o enquadramento, o não-lugar (posto de gasolina) e o silêncio das personagens em cena, nos remete a um quadro do pintor Edward Hopper e aquilo que ele mais gostava de retratar: a solidão urbana e a estagnação do homem. Já vimos, anteriormente, essa aproximação de Wenders com Hopper. Isso se dá, talvez, por uma certa afinidade do cineasta que adoraria ter sido um pintor, com o pintor que mais se assemelha a um cineasta, ao pintar quadros que nos 
contam histórias. Após a óbvia recusa silenciosa do menino, ele volta correndo para a estrada. Logo em seguida, a câmera aponta para aquele homem do caminhão, nu, tomando café, calmamente dentro da cabine. Ele sai do caminhão, veste um macacão jeans (Lee) e resolve enrolar um cigarro. Já no outro plano, temos um certo momento de suspense: o homem fecha os olhos e pisa fundo no acelerador.

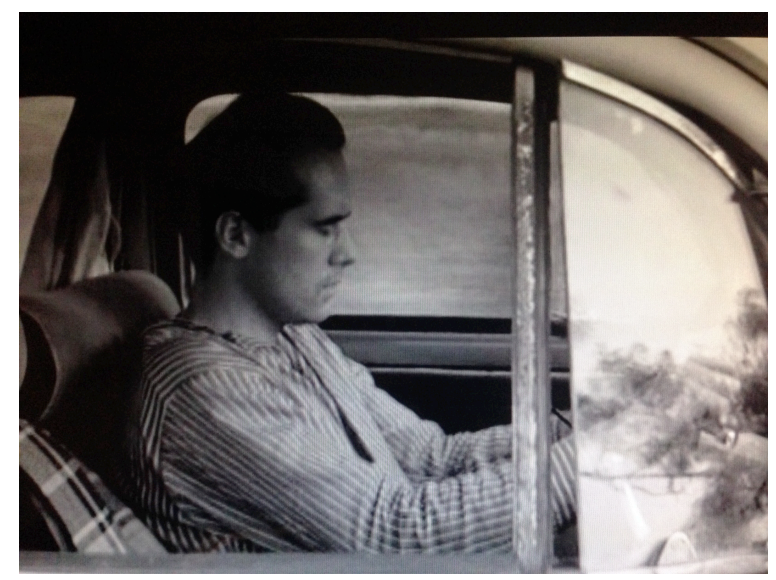

Figura 28: O personagem Robert acelera em busca do desconhecido

Enquanto o outro personagem - Bruno Winter - faz a barba, de pé, ao lado do caminhão, olha para trás e constata aquele fusca correndo feito um foguete e soltando fumaça atrás dele. $\mathrm{O}$ carro se dirige, com toda a intensidade, para dentro do rio. Bruno observa a cena e morre de rir dentro do caminhão. Logo após a tentativa de suicídio fracassada, o homem abre o teto solar do carro e observa a água que começa a inundálo. Ele sai com um paletó e uma maleta nas mãos e tenta nadar, com sofreguidão, em direção à margem do rio. Por um momento, os dois homens se observam. Bruno não consegue evitar o riso ao se lembrar daquela cena absurda. Ele oferece uma toalha e uma xícara de café. Sem ao menos mencionar uma só palavra, se estabelece, a partir daí, o início de uma amizade.

Essas são as cenas iniciais do filme. Reza a lenda que antes de dirigir o filme que encerra a sua trilogia on the road, No Decurso do Tempo (1976), Wim Wenders visitou todas as salas de cinema ao longo da fronteira das Alemanhas. Fotografou uns 120 cinemas e acabou escolhendo uma dúzia para as filmagens. O que vemos no filme não passa da metade das locações selecionadas. Na década de 70, o cinema alemão estava em plena crise, os que não fecharam, passavam pornografia - caso do cinema onde trabalhava a personagem Pauline. 


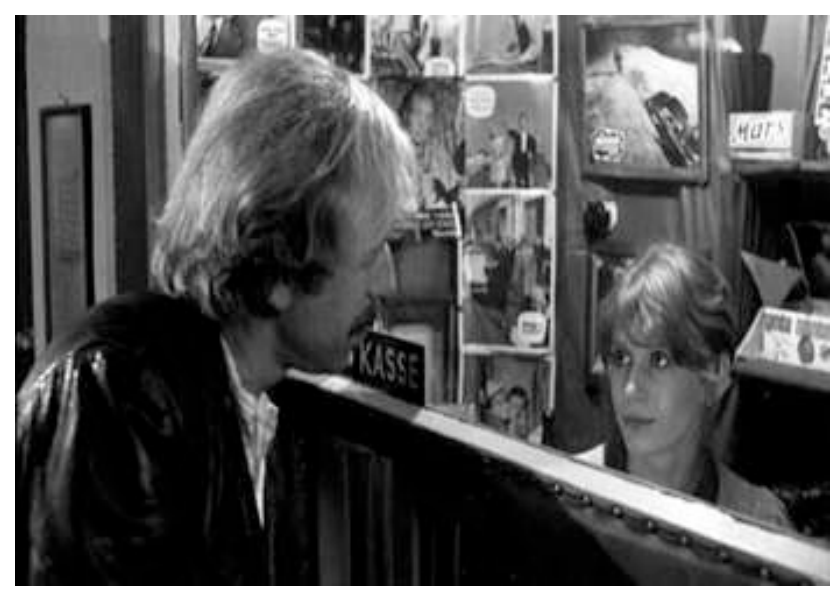

Figura 29: Bruno conta para Pauline os reflexos de um cinema equivocado

Bruno a encontra e mostra um trailer que montou: "90 minutos de cinema como a televisão nunca apresentou. Brutalidade, ação, sensualidade..." Soa como manifesto de Wenders contra um cinema equivocado. A maioria das sinopses sobre o filme em questão o descreve de uma maneira quase que telegráfica: "Técnico de projetores encontra um homem recém-separado e ambos iniciam uma amizade. Juntos, resolvem viajar pelas estradas da Europa." Mas sabemos que, na verdade, esse falso simplismo denota um cineasta que estava sob nítida influência do cinema de Antonioni, um dos cineastas mais cultuados dos anos $60 .{ }^{43}$ De sua filmografia, destacamos a trilogia da incomunicabilidade: “A Aventura" (1960), “A Noite" (1961) e "O Eclipse” (1962). Os recursos de linguagem adotados na narrativa, a composição da psique dos personagens, o vazio e o ensimesmamento nas relações humanas deram ensejo a que esses filmes fossem considerados emblemáticos na cinematografia mundial. Mesmo que, nos anos seguintes, tivessem sido identificados, negativamente, como "filme cabeça", pretensioso, distante, com uma estética contestável.

Sob a sua influência, Wenders parte em busca dos dilemas do sujeito contemporâneo, àquela altura dos anos 70 já corroído pelo esvaziamento dos ideais, afastando-se do comprometimento nas relações e fascinado pela perda. Com o objetivo de ressaltar esses temas, o diretor lança os personagens numa deriva, um movimento rumo a lugar nenhum, cujo significado encontra-se justo na ausência.

\footnotetext{
${ }^{43}$ Informação extraída do site: http://revistadecinema.uol.com.br/2012/08/trilogia-deantonioni/
} 
Para alguns críticos, as lentes de Wim Wenders estavam enriquecidas pela nostalgia do cinema como arte em destruição. Esse é o enfoque de "No Decurso do Tempo", uma certa versão desiludida de "Sem Destino" ${ }^{44}$, em que a estrada é a metáfora mais clara da vida, em que os encontros se tornam cada vez mais fortuitos ou dilacerantes, em que os traumas se constituem no único resíduo da existência.

No cinema de Wenders dessa fase, mover-se ou ficar parado conduz ao mesmo beco sem saída, mas o lirismo pela busca de um cinema que não pode fenecer é o que torna esse filme tão especial, principalmente, para aqueles que ainda acreditam na magia inesgotável dessa linguagem inspiradora para tantas outras artes.

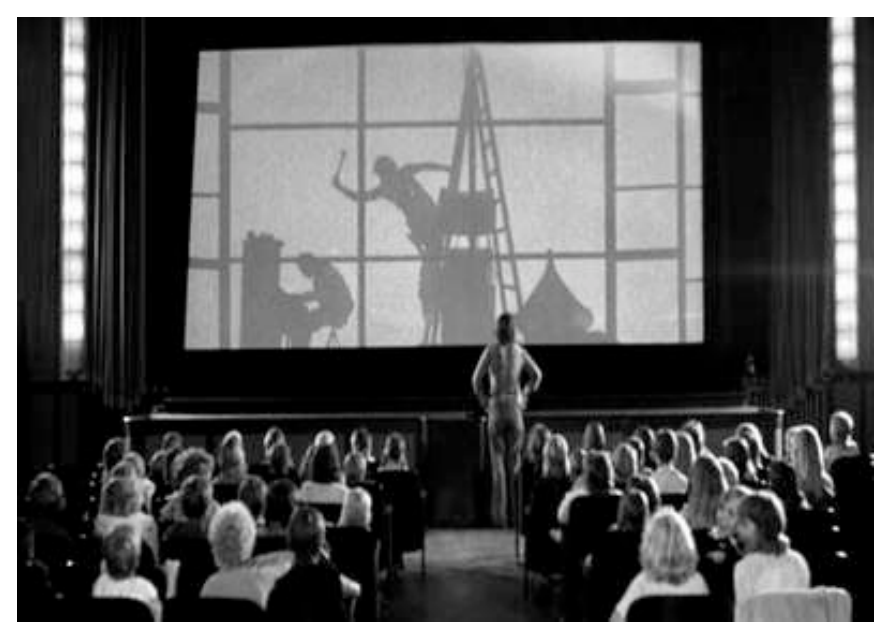

Figura 30: Os personagens Bruno e Robert improvisam um teatro de sombras

E no que tange à magia, uma das citações mais bonitas do filme acontece na seqüência em que um grupo de crianças espera que Bruno e Robert resolvam os problemas técnicos para dar início à sessão de cinema (vide imagem acima). Eles estão atrás da tela, quando Robert acende a luz para ajudar Bruno e percebem suas sombras

\footnotetext{
${ }^{44}$ Esse filme é um marco dos road movies americanos, escrito, em 1969, por Peter Fonda, Dennis Hopper e Terry Southern, produzido por Fonda e dirigido por Hopper. Conta a história de dois motociclistas que viajam através do sul e sudoeste dos Estados Unidos, com o objetivo de alcançar a liberdade pessoal. O sucesso de Easy Rider ajudou a avivar a fase New Hollywood do cinema norteamericano durante a década de 1960. Um marco na filmografia de contracultura e a "pedra-de-toque" de uma geração que "capturou a imaginação nacional", Easy Rider explora as paisagens sociais, assuntos e tensões na América da década de 1960, tal como a ascensão e queda do movimento hippie, o uso de drogas e estilo de vida comunal.
} 
projetadas na tela - como num teatro de sombras. Eles sabem que as crianças podem vêlos e partem, de maneira lúdica, para cenas de comédias.

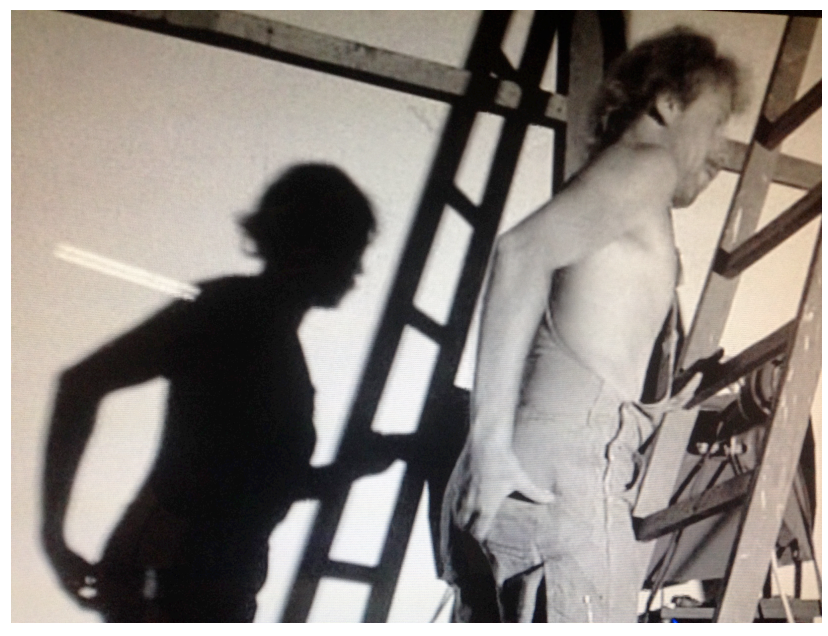

Figura 31: No teatro de sombras, um projecionista também pode ser um macaco

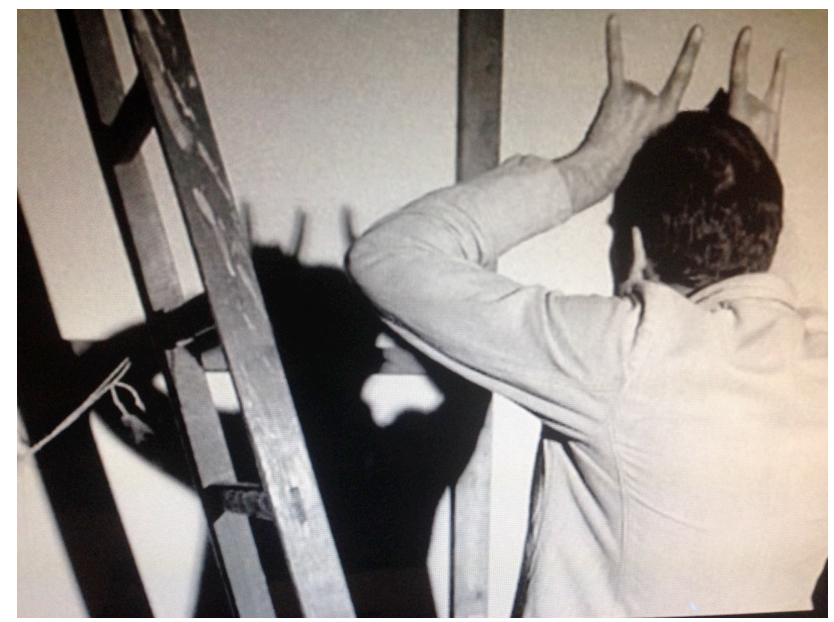

Figura 32: Na brincadeira, a sombra refletida traz o encantamento infantil

Nessa bela homenagem à pré-história do cinema com suas sombras, as crianças se divertem e se esquecem do filme que deveriam assistir. Nessa seqüência de cenas, vemos como o cineasta se apropria de maneira poética de um cinema da infância que se inicia na infância do cinema. Esse foi o começo poético de uma linguagem que adoraríamos que não tivesse fim. Em um teatro de sombras, a silhueta das mãos aparece projetada na tela graças a uma fonte de iluminação colocada por trás. Esse espetáculo parece ter-se originado na China: conta-se que no século II antes de Cristo o imperador Wu-Ti teria se consolado da morte de sua esposa ao ver a silhueta dela projetada numa tela. As sombras chinesas só chegaram à Europa no fim do século XVII e ainda são o 
meio mais simples de contar uma história através de imagens em movimento. Em Java, esse costume existe até hoje. Por lá, o operador das marionetes ou dalang fica sentado atrás da tela. Acompanhado por uma orquestra, ele conta as lendas dos deuses (MARCHAND, 1996. p.2).

Para Wenders, o cinema é o espelho adequado das cidades do século XX e dos homens que vivem nela. O cinema é uma cultura urbana. Nasceu no final do século XIX e se expandiu com as grandes metrópoles do mundo. O cinema e as cidades cresceram juntos e se tornaram adultos juntos. O filme é a testemunha desse desenvolvimento que transformou as cidades tranqüilas da virada do século nas cidades de hoje, em plena explosão, febris, onde vivem milhões de pessoas. Conforme enfatizou: ${ }^{45}$

\begin{abstract}
Mais que outras artes, o cinema é um documento histórico do nosso tempo. Esta que chamam de sétima arte é capaz, como nenhuma outra arte, de apreender a essência das coisas, de captar o espírito do tempo, de exprimir suas esperanças, suas angústias e seus desejos numa linguagem universalmente compreensível.
\end{abstract}

No filme, o cineasta se utiliza de algumas metáforas dialógicas para mostrar o quanto existem afinidades entre a História e o desenrolar próprio da história das personagens. O tempo fílmico, muitas vezes, está impregnado daquilo que se viveu e de todo um legado que marcou gerações e, por isso, não é possível esquecer. Ainda segundo Wenders, ${ }^{46}$ as cidades não contam mais histórias, mas podem contar algo sobre a História. As cidades podem trazer em si sua história, e mostrá-la, podem torná-la visível ou ocultá-la. Como os filmes, elas podem abrir seus olhos ou fechá-los. Elas podem esvaziar ou alimentar sua imaginação. É possível ver o apreço que existe, no filme, entre o desenrolar do tempo e a história. Em uma das cenas do No Decurso do Tempo, Bruno levou Robert à velha casa de sua infância, na beira do Rio Reno, onde morou com a mãe. Admitiu ter gostado de voltar lá: "Pela primeira vez, eu me vejo como alguém que viveu certo tempo, e esse tempo é minha história". Reconciliado consigo mesmo, Bruno pode medir o caminho percorrido e reencontrar sua identidade. Alguns quilômetros antes, Bruno disse a Robert que queria saber quem ele era. Resposta de Robert: "Eu sou minha história".

\footnotetext{
${ }^{45}$ Revista do Patrimônio - número 23/1994. Texto de Wim Wenders publicado em La Verité des images, Paris, L'Arche, 1992. Intervenção feita em inglês em um colóquio de arquitetos japoneses realizados em Tóquio, em 12 de outubro de 1991.

${ }^{46}$ Idem, página 10.
} 


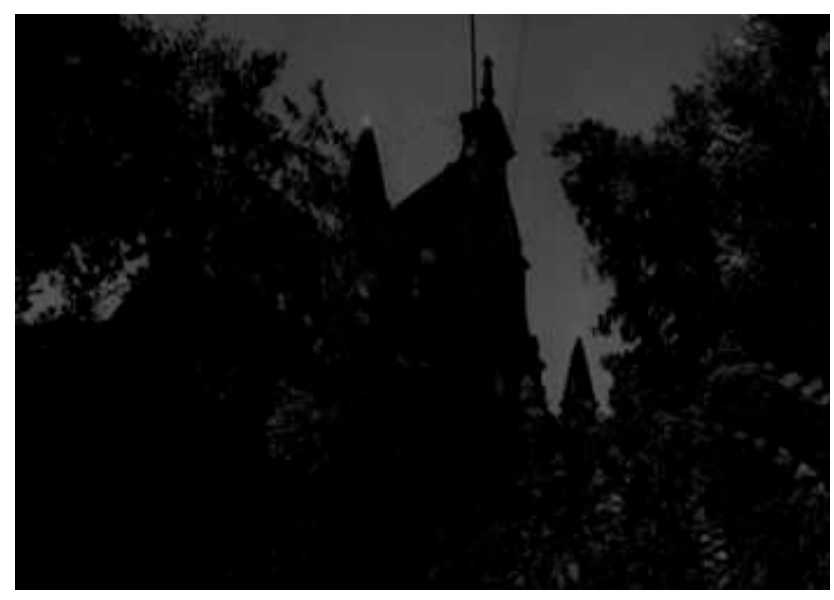

Figura 33: No Decurso do Tempo - sombras duras e bem demarcadas do Expressionismo Alemão

De acordo com a pesquisadora Maria Beatriz Colucci, no artigo intitulado "Olhares Expressionistas em Wim Wenders", ${ }^{47}$ relacionar Wenders ao expressionismo pode parecer um contra-censo, porque sublinha-se sempre - e com razão - sua estreita ligação com o cinema americano. Mas, mesmo assim, é possível encontrar em seus filmes alguns vínculos com o cinema alemão de influências expressionistas, conforme o fotograma destacado acima e a descrição que se segue.

Cheia de contrastes e sombras bem demarcadas, esta seqüência também foi uma homenagem de Wenders ao cinema expressionista alemão da década de 20 do século passado - uma herança alemã que precede as memórias nazistas. É nesse período que se situa a escola do expressionismo alemão tão bem representada pelo "Gabinete do Dr. Caligari", e que produziu obras muito importantes, além de revelar realizadores do porte de Friedrich Wilhelm Murnau e Fritz Lang, a quem Wenders faz reverência.

A Alemanha da época do Expressionismo Alemão vivia uma humilhante derrota na Primeira Guerra Mundial, uma crise econômica sem precedentes e buscava reencontrar sua identidade e liderança perdidas. Nessa Alemanha inferiorizada e subjugada, as expressões artísticas teriam de ser intensas, algo lúgubres e inevitavelmente pessimistas. $\mathrm{O}$ expressionismo já existia na pintura, na música, na poesia e no teatro. Levado ao cinema, acabou por alcançar um alto grau de sofisticação, deixando uma marca permanente na chamada sétima arte, em seu período silencioso.

\footnotetext{
${ }^{47}$ COLUCCI, Maria Beatriz. "Olhares expressionistas em Wim Wenders". Lumina - Facom/UFJF - v. 2, n.2, p. $49-65$
} 
Além disso, ao mesmo tempo em que traduz certo aspecto da cultura alemã, o expressionismo foi um grito de alerta para os horrores da guerra - no caso, a Primeira Guerra Mundial. Subindo ao poder, Hitler irá banir obras expressionistas como arte degenerada. O jogo de luz e sombra no cinema expressionista traduz também um aspecto soturno (melancólico e sombrio) e solitário que para alguns caracteriza o espírito germânico. Portanto, Bruno admitir que gostou de visitar o lugar também carrega esta carga simbólica. Sob as influências do Expressionismo Alemão, a seqüência não mostra apenas um lugar físico, mas também uma época do cinema que teria sido capaz de trazer da literatura alemã um traço básico da herança cultural daquele país.

No Decurso do Tempo poderia ser classificado "apenas" como um filme de estrada (road movie), afinal Wenders sempre gostou desse tema. Mas o filme vai um pouco além do simples "deambular". Quando o filme estava sendo apresentado no Festival de Cannes em 1976, Wenders esclareceu que a peregrinação sem fim de Bruno e Robert ao longo da fronteira das Alemanhas, mais se assemelha a uma viagem psicanalítica. Além disso, quanto ao aspecto road movie do filme, o cineasta explicou que pensou mais em Terra Bruta (Two Rode Together, direção John Ford, 1961) do que em Sem Destino (Easy Rider, direção Dennis Hopper, 1969). Não é difícil imaginar o porquê dessa lembrança. Quando pensamos nos filmes do John Ford sempre vêm à memória uma composição, um quadro, um cenário, uma paisagem, enfim, uma imagem que beira à perfeição. Filmes que captam um fragmento do mundo visível rigidamente organizado, enquadrado, refletido, mas atravessado pelo vento irracional da natureza e pelas forças contraditórias do homem. Após assistirmos o No Decurso do Tempo se torna mais fácil entender como se deu essa identificação de Wenders, o seu espelhamento. 


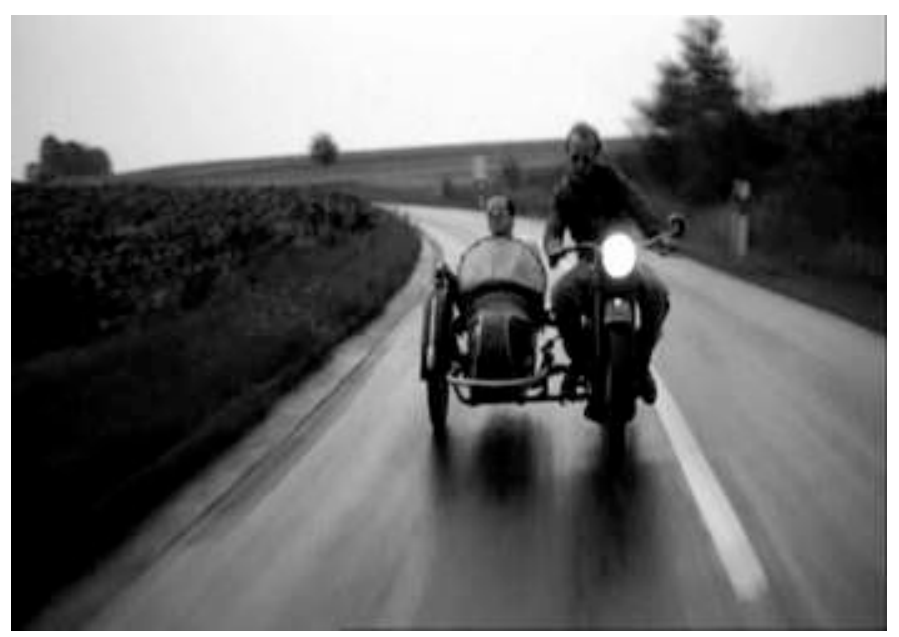

Figura 34: Bruno e Robert embarcam no espírito da estrada

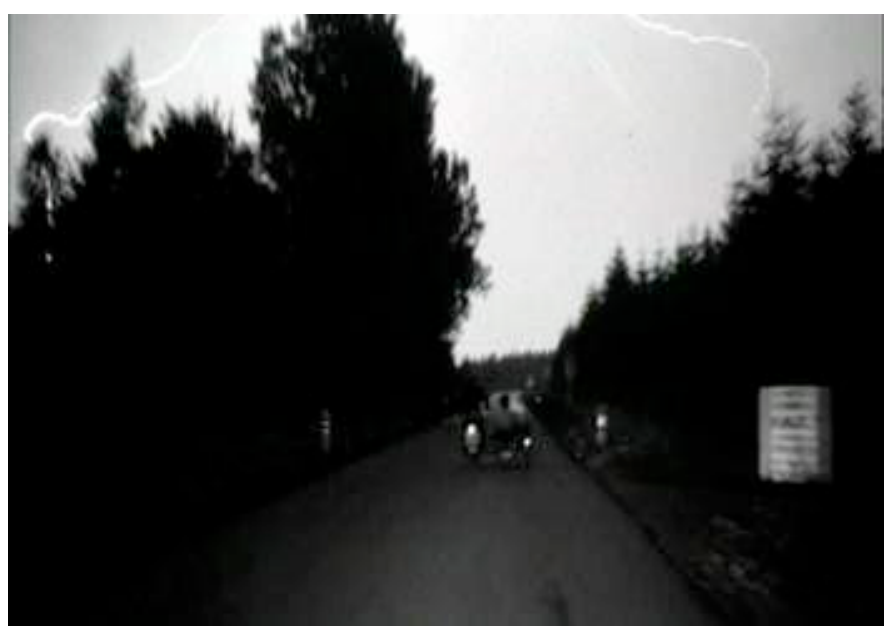

Figura 35: Bruno leva Robert para (re)conhecer o seu passado

A andança sem rumo ali seria também indicação do soturno e solitário germânico. Mesmo que não houvesse por trás da errância física e espiritual de Robert e Bruno o fantasma do passado/nazismo, a herança expressionista sugere uma visão de mundo angustiada. Como ressaltou Lotte Eisner, ${ }^{48}$ a literatura expressionista tinha um caráter contraditório bem característico do "espírito alemão". Do ponto de vista da História da Arte, ainda que o expressionismo reagisse contra o impressionismo e o naturalismo, compartilhava com ambos alguns elementos. Com relação ao claro-escuro do cinema expressionista, Eisner esclareceu que "a verdadeira Alemanha (...) prefere muito naturalmente a penumbra à luz".

${ }^{48}$ EISNER, Lotte. A tela demoníaca. Tradução de Lúcia Nagib. Rio de Janeiro: Paz e Terra, 1985. 


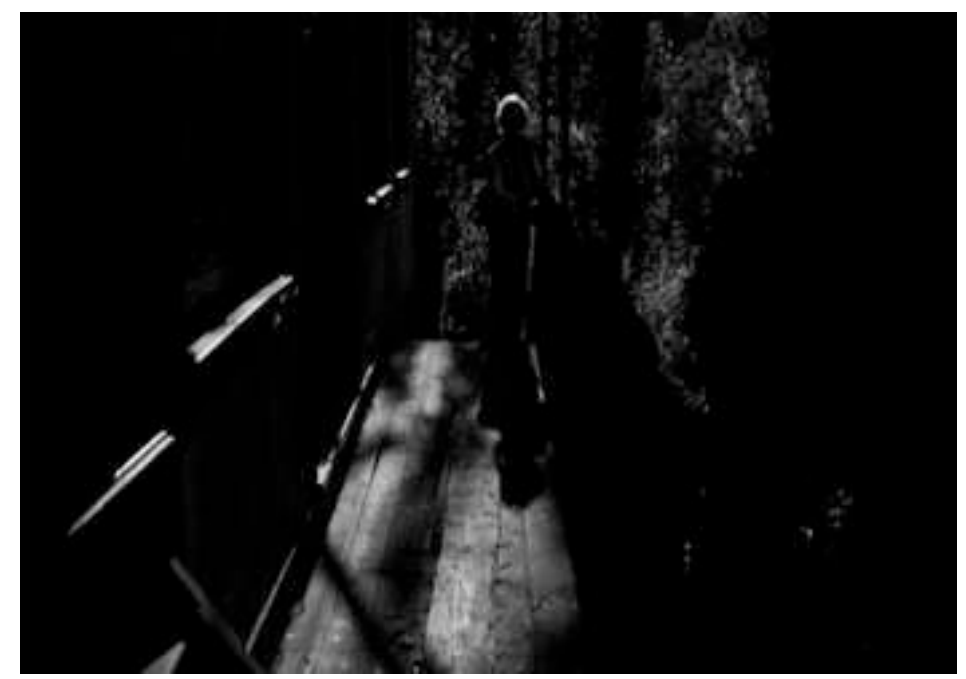

Figura 36: Bruno representa o "claro-escuro" do cinema expressionista alemão

\author{
O expressionista já \\ não vê: ele tem "visões". \\ (...)A cadeia de fatos (...) não existe; só existe a visão \\ interior que provocam ${ }^{49}$
}

Eisner explicou que na época do cinema mudo as cópias eram tingidas de marrom, verde ou azul escuro (técnica conhecida como viragem), principalmente nas cenas noturnas - que a película de então era incapaz de reproduzir. Portanto, as nuanças eram maiores do que encontramos na maioria das cópias que chegaram a nós. Além disso, continua Eisner, existe no espírito alemão predileção pelo marrom, o acastanhado (o sépia em alguns filmes mudos) e fatalmente a sombra. O marrom, ausente do arcoíris, estaria na fronteira do claro-escuro. Nas duas imagens acima, vemos o clima misterioso e soturno da citação expressionista de Wim Wenders durante a visita à casa da mãe de Bruno.

Na primeira seqüência do filme, conforme descrevemos no início do capítulo, Bruno conserta o projetor e escuta um velho proprietário. Ele conta que esteve lá desde o cinema mudo. Depois da guerra teve problemas porque pertenceu ao Partido Nazista, mas conseguiu reaver seu cinema. $\mathrm{O}$ velho percebe a crise pela qual o cinema passa, mas é otimista em relação ao futuro. Na penúltima seqüência, Bruno está noutro cinema

\footnotetext{
${ }^{49}$ Kasimir Edschmid apud Lotte Eisner . op. cit.
} 
fazendo manutenção - à sua volta vêem-se fotografias de atrizes seminuas. A velha proprietária se ressente da crise - cinemas fechando e pornografia. Enquanto fala, percebemos atrás dela a fotografia de um "pai”. É Fritz Lang, o cineasta que dirigiu Metrópolis (1927), os filmes com Dr. Mabuse (1922 e 1933) e Os Nibelungos (1924) que assiste atônito, imóvel e incrustrado na parede, o discurso da velha senhora:

\begin{abstract}
Meu pai disse que filme é a arte de ver e por isso não consigo mais mostrar esses filmes que são simplesmente a exploração de tudo que se possa explorar nos olhos e na cabeça das pessoas. Mas eu não exibo filmes dos quais as pessoas saem estarrecidas e anestesiadas de ignorância, nos quais qualquer vontade de viver é destruída, nos quais morrem qualquer sentimento por si mesmo e pelo mundo. Meu pai queria que eu mantivesse um cinema aqui, neste lugar. Eu também. Mas, do jeito que está, é preferível não ter mais cinema a ter um como o que temos agora.
\end{abstract}

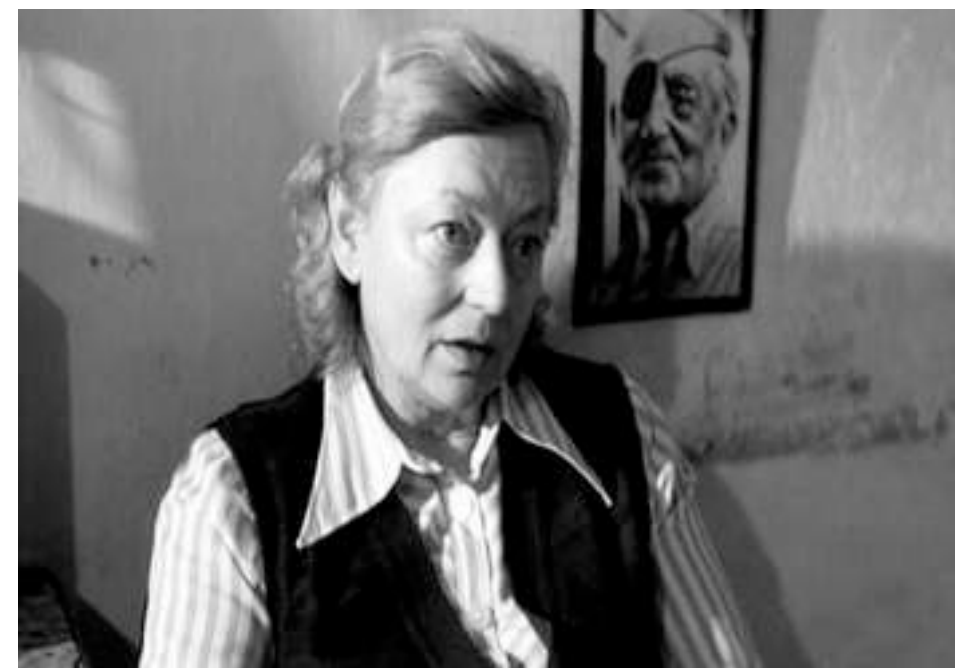

Figura 37: A velha senhora desapontada com a crise do cinema alemão

Ela ecoa a reclamação de Wim Wenders contra o que ele chamou de "cinema de exploração" - o pornô seria o "resultado lógico, o estado final". As palavras dela remetem a um problema profundo na indústria cinematográfica na Alemanha dos anos 60 e 70. Um projeto de lei com subsídios para o cinema aumentou o número de filmes, mas quebrou o mercado. Pornografia e comédias adolescentes davam mais lucro, porém cansavam mais rapidamente o público - sim, filmes pornográficos recebiam subsídios do governo. Como a produção estava na mão dos distribuidores, os cinemas eram forçados a passar pornôs para que pudessem então "passar filmes" - o país foi o maior produtor de pornografia leve da Europa. 


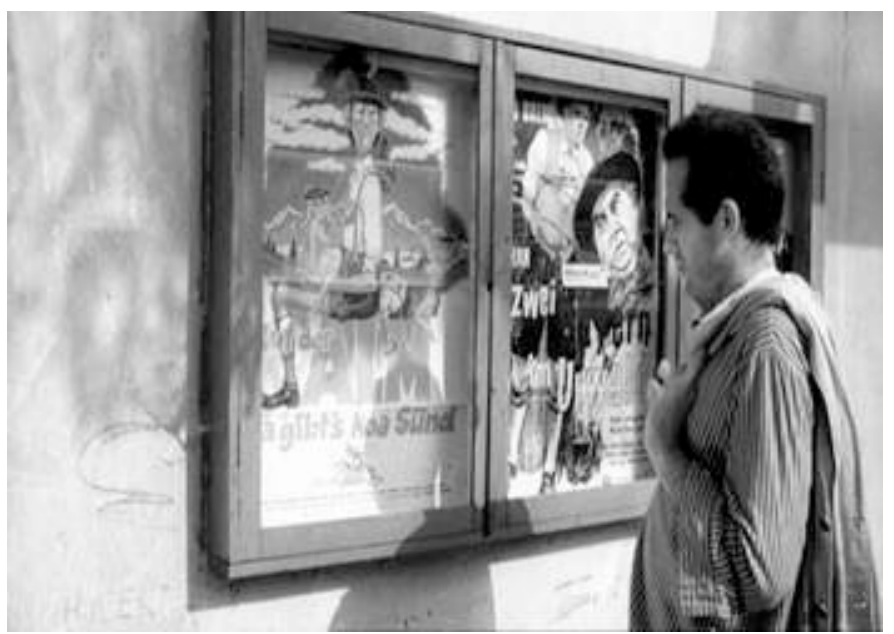

Figura 38: Robert observa um cartaz de filme pornô

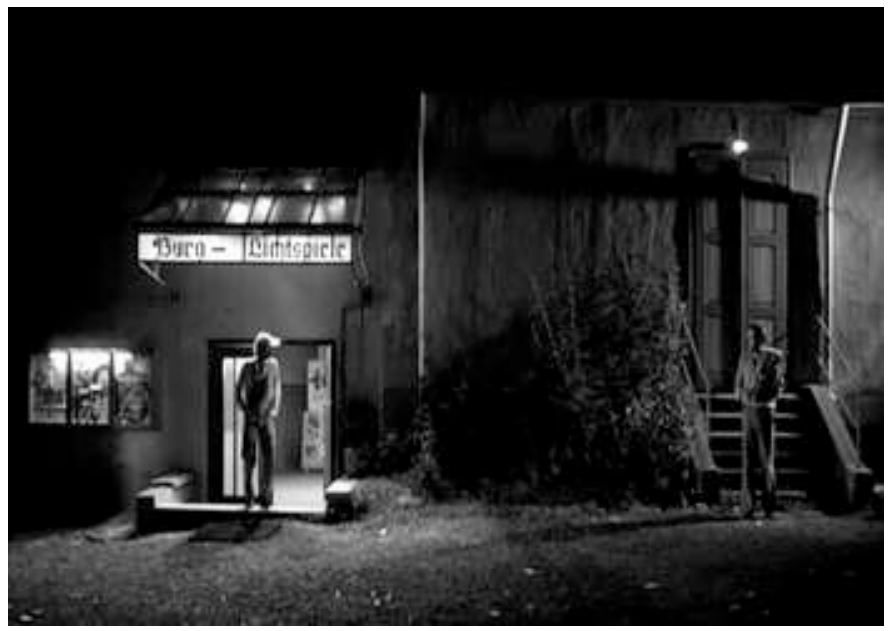

Figura 39: Bruno e Robert na frente de mais um cinema pornô alemão

Isto arruinou o mercado e fechou todos os cinemas em cidades pequenas. No final dos anos 60, quase todo o cinema da Alemanha Ocidental era pornografia. No Brasil, ainda hoje, a realidade nua e crua não é lá muito diferente. Com o passar do tempo, a multiplicação dos multiplex, a TV a cabo, o DVD, a internet, talvez a única forma de atrair espectadores para os cinemas de rua fosse exibindo sexo nas telas. Convenhamos que esse futuro não é lá muito animador para quem ainda preza aquele ritual delicioso de sair de casa para assistir a um "filme de cinema". Algo bem diferente daquele DVD ou filme na televisão a cabo, no cinema temos um belo ritual que merece ser respeitado. Ao apagar das luzes, escolhe-se o melhor lugar que, por incrível que pareça, pode ser ao lado de uma pessoa estranha, assistimos o trailer das próximas sessões, desligamos aquele "apêndice eletrônico" chamado celular e mergulhamos no inefável mundo do cinema. Mas, infelizmente, temos perdido muitas das nossas salas de 
cinema para a construção de shoppings centers, estacionamentos, salas comerciais e templos evangélicos. Para termos uma ideia, vale a pena ler o relato do jornalista Guilherme Assis, na matéria intitulada "Memórias em 35mm": ${ }^{50}$

\begin{abstract}
Brasília tem 77 salas de cinema. Aqui, por exemplo, um prédio no centro de Taguatinga, famoso por ser uma das primeiras construções de alvenaria da cidade, foi casa do Cine Paranoá. Lá era festa! Alunos saíam mais cedo do colégio e trocavam os uniformes por camisetas. Tudo para burlar a entrada, que era fiscalizada. O cinema contava com uma sala de espera ampla, após a entrada, com grandes sofás confortáveis revestidos em couro. Logo ao centro do salão principal, um platô com expositores e fotos dos filmes que eram(?) exibidos, segundo a Administração da cidade. A primeira exibição no local, o filme Hércules de Tebas (Giorgio Ferroni, 1964, Mark Forest como Hercules). Anos depois, viraria ponto de encontro para quem procurava sexo. De Hércules a Dionísio. Mais tarde se tornou uma igreja. Ou melhor, duas igrejas. O prédio que hoje se chama Paranoá Center, já foi palco para pastores da Igreja da Graça de Deus e da Igreja Mundial do Poder de Deus, ambas com relações indiretas a Igreja Universal, conhecida por fechar vários cinemas e construir templos exuberantes.
\end{abstract}

No filme, o desapontamento não é lá muito diferente. Quando Bruno e Robert chegam ao cinema Berg Lichtspieler, Robert descobre o cartaz de um pornô leve (Auf der Alm da Gibt's Koa Sünd, 1974). Em 1982, Wenders realizaria Quarto 666, e por lá perguntava aos cineastas: $\mathrm{O}$ cinema continuará a existir como forma de arte? $\mathrm{Ou}$ estávamos realmente testemunhando seu fim? Ele será substituído por outra coisa como a TV ou outra forma de imagem gerada eletronicamente? Godard, no plano estático filmado por Wim Wenders, acende um cigarro e fala, pausadamente, enquanto, ao fundo, uma televisão transmite uma partida de tênis. Vale a pena relembrarmos a sua fala poética: ${ }^{51}$

Filmes são feitos de imagens. As imagens são feitas quando não tem ninguém olhando. Isso é o invisível, aquilo que não vemos. O inacreditável é isso. Aquilo que não vemos. E o cinema nos mostra aquilo que não vemos. Eu estou aqui de frente para câmera. E ainda sobre o meu corpo e a minha cabeça, estou atrás dele. O meu mundo é o imaginário. E o imaginário é uma viagem entre o passado e o futuro. E, como Wim, sou um grande viajante. Bem..., até mais ver.

Fassbinder, no filme, também dá o seu depoimento de maneira sintética e enfática: ${ }^{52}$

\footnotetext{
${ }^{50}$ ASSIS, Guilherme. "Memórias em 35mm" publicada na revista-laboratório Jenipapo, da UCB, em setembro de 2012, p. 15.

${ }^{51}$ Depoimento de Jean-Luc Godard extraído do filme Chambre 666, dirigido em 1982, pelo Wim Wenders.

52 Depoimento de Fassbinder. idem
} 
Temos poucos filmes sendo feitos. Isso é verdade. Os filmes estão sendo polarizados. Por um lado, temos um cinema orientado para a sensação que pretende ser bombástico, colossal. Por outro lado, há um cinema muito individual ou um cinema nacional de realizadores individuais que é muito mais importante hoje, aquele cinema que é inestiguível da televisão.

Consideramos relevante ressaltar o depoimento do Herzog, companheiro de Wenders, na estética desse Novo Cinema Alemão. Antes de falar, Herzog olha para trás e desliga a televisão: ${ }^{53}$

Eu acho que vou começar tirando os sapatos. Você não pode responder uma questão dessa com os sapatos calçados. Eu não vejo a situação de maneira dramática como a questão parece implicar. Eu vejo isso dizendo que não somos tão dependentes da televisão. A estética do cinema é algo à parte, separado. A TV é uma espécie de juke-box. Você nunca está dentro do espaço do teatro ou mesmo dentro do filme. Como espectador, você tem um tipo de posicionamento móvel. E você pode desligá-la. Você não pode desligar um cinema.

A fala de Herzog se mostra precisa e coaduna com as cenas que vimos nos filmes de Wenders quando ele nos mostra a sua insatisfação com a televisão e, ao mesmo tempo, quase sem querer, quando descreve, posteriormente, toda as mudanças que ocorrem com as novas tecnologias e o nosso modo frio, preguiçoso e distante de nos relacionar com ela. O cinema para Herzog é uma sensação que requer uma presença, uma fruição, um estar dentro e perto. Para ele, não há motivo para preocupação. O cinema nunca será obliterado pelo vídeo ou pela televisão. Após toda uma digressão, em quase quatro minutos de fala, ainda em um plano estático, sentado na poltrona, ele anda nos diz de maneira contundente: "Eu não estou preocupado com a câmera ou com o filme. Apesar do que aconteça lá, não é assim que a vida acontece. A vida está indo para outro lugar, a vida é dinâmica. A vida nos toca diretamente.”

Após toda essa reflexão sobre a permanência do cinema, retrocedemos alguns anos (seis, mais precisamente) e cortamos, novamente, para o filme No Decurso do Tempo. Depois de ouvir o triste depoimento daquela senhora e o seu total desapontamento com um cinema que só tem pornografia e abandonou, quase que por completo, a sua arte, Bruno volta a seu caminhão. Na fachada do cinema lemos seu nome: Weisse Wand (Parede Branca). Esse luminoso, de alguma forma, denota uma dúvida, um incômodo, um porvir. O branco de uma parede que espera alguma imagem a

53 Depoimento de Herzog, idem. 
ser projetada. Não por acaso, as letras que foram projetadas (WW) reforçam o nome de Wim Wenders. Ele, assim como outros cineastas que descrevemos acima, também acredita na continuidade das projeções dos filmes de cinema.

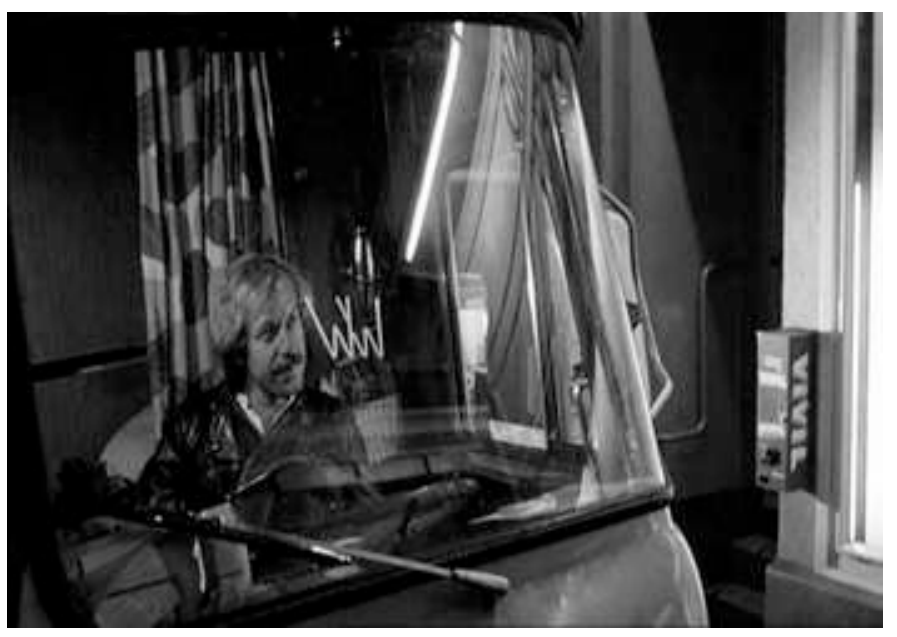

Figura 40: Dentro do caminhão, as duas iniciais se refletem no rosto dele: WW (Weisse Wand (parede branca)/Wim Wenders)

“É preciso mudar tudo!" Com esta frase num bilhete Robert se despede de Bruno. Cada um toma seu rumo, acompanhamos uma espécie de dança entre o caminhão de Bruno e o trem que leva Robert. No vai-e-vem entre caminhos paralelos e cruzamentos, desenha-se a metáfora visual da vida e a dúvida por um novo cinema, que aglutine as novas linguagens, mas que não perca a força da sua narrativa. Um cinema que esteja no caminhos dos road movies, que assim como os personagens Philip Winter, Wilhelm Meister e Bruno Winter, não desista da sua busca, sem jamais desconsiderar as próprias indagações. Por um momento, juntos. Noutro, juntos, mas separados. Como num jogo entre claro-escuro, as pessoas parecem tão perto e ao mesmo tempo tão longe. Como lidar com as memórias do passado? O que fazer com um passado que não pára de voltar? O passado sempre foi um problema para a geração pós-guerra na Alemanha. Cineastas como Wenders, que nasceu em 1945, sabem disso. O legado nazista era tabu, uma vez que a geração mais velha, conscientemente ou não, baniu todas as questões sobre o passado recente alemão. Em meados da década de 60, depois do julgamento de Adolf Eichmann, a geração mais nova questionou seus pais a respeito do envolvimento com Hitler. Uma crise irrompeu entre as gerações - os mais velhos eram sempre considerados culpados. 
Wenders abandonou a tradição cinematográfica alemã e buscou inspiração em diretores norte-americanos, conforme mencionamos nos capítulos anteriores. A força unificadora do Cinema Novo alemão na década de 60 foi a rejeição da tradição Nacional Socialista no cinema. Em 1962, com o famoso Manifesto de Oberhausen, cineastas como Herzog e Fassbinder rompiam com os filmes de seus "pais" em todos os sentidos - produção, conteúdo, forma e estilo. Wenders filma, a seu modo, a solidão e a desconexão social - pais sozinhos na frente dos filhos (Alice nas Cidades e Paris, Texas, homens desajeitados, perdas de identidade (Movimento em Falso, No Decurso do Tempo, Asas do Desejo). Não por acaso, um personagem que representa um industrial, à beira do suícidio, que hospeda por uma noite Wilhelm e todos que estavam com ele, no filme Movimento em Falso nos falou sobre a solidão, relacionando-a às profundezas dos alemães:

Gostaria de falar rapidamente sobre a solidão na Alemanha. Ela me parece
mais escondida e ao mesmo tempo mais dolorosa do que em qualquer outro
lugar. (...) O medo é considerado um sinal de vaidade ou também é sentido
como fraqueza. Por isso a solidão na Alemanha é mascarada. Mascarada por
todos esses rostos desleais, brilhantes e desalmados que vagueiam por
supermercados, centros de lazer, calçadões e turmas noturnas de academias
de ginástica. As almas mortas da Alemanha.

Como Werner Herzog, Wim Wenders foi filmar em outros países - embora seus personagens geralmente se comportassem como exilados. Quando filmou na Alemanha, Herzog o fez de um ponto de vista pré-humano ou infra-humano, com uma nuvem de ratos em Nosferatu, o Vampiro da Noite (Nosferatu, Phantom Der Nacht, 1979) refilmagem do clássico do cinema mudo expressionista de Murnau. Já Wenders filmaria, alguns anos depois, do ponto de vista supra-humano de um anjo, como em Asas do Desejo. Os filmes de Wenders e Herzog cavam sempre a mesma metáfora da Alemanha: um país transformado em deserto de pedra, ferro, betume ou clorofila. No Decurso do Tempo fecha esta trilogia inicial de Wenders feita de incomunicabilidades, de busca de identidade, desse cinema de tempos mortos, que antecede momentos transparentes na naturalidade das ações e dos gestos. Neste filme, mais uma vez, a narrativa fica por vezes suspensa, como se desprovida de peso, detendo-se sobre um gesto, um sinal, uma palavra, um silêncio, uma imagem. Aqui ele deixa uma semente e, ao mesmo tempo, um legado de um cinema espantosamente concreto e, no entanto, em deslocamento constante. 


\section{5 - Conclusão - Uma estrada sem fim}

Neste capítulo, abriremos novas perspectivas de análise com a conclusão. Aqui será investigado como esses três temas - viagem, identidade e incomunicação - se interrelacionam. O viajante, essencialmente, busca conhecer a si mesmo com todos os riscos. O meio de transporte utilizado pode ser um recurso para uma imersão. Um mergulho no desconhecido, em lugares ou no silêncio de si mesmo. Pegar a estrada é o mesmo que satisfazer a curiosidade de pertencer a outro lugar. Como um herói que enfrenta inimigos e batalhas, o viajante luta por uma nova identidade ou, quem sabe, um resgate dela. Independente do lugar que esteja sempre será um estrangeiro. Por isso, as formas de se relacionar e interagir numa outra cultura, por mais globalizada que seja, nunca é a mesma. O desenrolar da sua história pessoal acontece ao longo dos quilômetros de estrada e paisagens percorridas. As imagens refletidas no pára-brisa do carro e as pessoas encontradas pelo caminho começam a fazer sentido. Essa experiência também é uma maneira cronológica de fazer cinema. Nessa trilogia de road movies de Wenders, percebemos o quanto as viagens e os seus personagens nos contam histórias. História de um gênero de cinema sensível ao movimento, ao espaço, às paisagens urbanas e a maneira como tudo isso se inter-relaciona com as narrativas pessoais de cada personagem.

Em todos os filmes, Wenders usa a fotografia como uma paisagem pintada por Hopper. Fotografia é história. A solidão, as angústias e incertezas estão presentes naqueles não lugares. Aeroportos, postos de gasolina, lanchonetes e estradas servem de pretexto para um questionamento ou uma incomunicação entre as personagens e a própria gênese da imagem. Será que a fotografia revela "um real"? A força do cinema está na imagem ou na narrativa? A televisão acabou com a magia do cinema? O que será feito do cinema em tempos de realidades cada vez mais virtuais? Wenders, a seu modo, nos responde com uma linguagem particular. A fotografia, a música, os enquadramentos, a caracterização das personagens, os cenários, espaços e vazios, tudo isso serve ao cinema. Uma possibilidade de narrativa sai da literatura para percorrer as estradas do cinema. Conforme constatamos, o gênero road movie é um mapa da cultura e das suas significações. 
À primeira vista, percebemos que a análise da estrutura narrativa da produção cinematográfica de Wim Wenders possibilita uma interpretação sociológica, a partir de seus road movies, da Alemanha - embora um dos filmes analisados se passe nos Estados Unidos (Alice Nas Cidades). Wenders, com as suas lentes, nos mostra um país com um certo sentimento de culpa, dividido, ressabiado, fragmentado e, por vezes, melancólico. No entanto, vai além disso. A seu modo, busca encontrar o equilíbrio entre as mudanças do mundo e seu esforço de se manter ancorado a um ponto de vista radical. O seu cinema se descobre nas estradas e passeia por inúmeras paisagens áridas e silenciosas, com o objetivo de retratar as relações humanas, a fuga, a solidão, a incomunicabilidade, o deslocamento e a maneira como, muitas vezes, não reconhecemos a nossa própria identidade cultural; proposições apreendidas, possivelmente, das pinturas do americano Edward Hopper, conforme mencionamos, uma referência fundamental em seu cinema. Filmes feitos de incomunicabilidade e de busca de identidade: é um cinema de tempos mortos, que antecede momentos transparentes, com suas intepretações naturalistas, onde a narrativa fica, por vezes, suspensa como se desprovida de peso, detendo-se sobre um gesto, um sinal, uma palavra, um silêncio, uma trilha, uma imagem.

O que ele busca em sua obra é percorrer a estrada com a liberdade e a ousadia que pretende descobrir o fazer cinematográfico, rompendo fronteiras culturais, pensando na gênese e na transição das mais diversas linguagens audiovisuais, sem nunca negar o seu amor e engajamento ao cinema. Hoje em dia, sabemos que o cinema contemporâneo mais avançado deixou de ser linguagem - e espetáculo - para tornar-se estilo, cheio de maneirismos no momento de filmar. No entanto, o realizador atual dispõe de uma forma de expressão tão ágil e sutil quanto a linguagem escrita. Aquilo que Wim Wenders alertava, em plena década de 70, já se consumou. Com o advento das novas mídias e toda a pirotecnia que alguns novos realizadores fazem sobre ela, o cinema vem perdendo a sua identidade. Identidade, para Wim Wenders, é a sua palavra favorita, conforme ele mesmo diz: ${ }^{54}$

Gosto até do som dela: "identidade". Adoro a canção de Monica Tomasi Samba de identidade, porque só tem o título e ainda assim é uma grande música. (Poderíamos apenas escutá-la e eu não precisaria descrevê-la.) Mas o que é identidade? Estar bem consigo mesmo, em paz consigo mesmo, manter o eixo, saber quem você é e qual o seu valor. A identidade é formada e

\footnotetext{
54 AXT, Günter e SCHULER, Fernando Luir (org). Fronteiras do pensamento: ensaios sobre cultura e estética. Rio de Janeiro: Civilização Brasileira, 2010. p.399
} 
definida por fronteiras, por limitações e por escolhas, e não por opções sem limites, decisões aleatórias. A identidade é modelada e produzida pela experiência, não é algo que se tem assim, pronto nas mãos. Experiência, por sua vez, só é possível onde existe abertura, para o outro, para a vida, para a curiosidade, para a prendizagem, para as fronteiras e também para a liberdade.

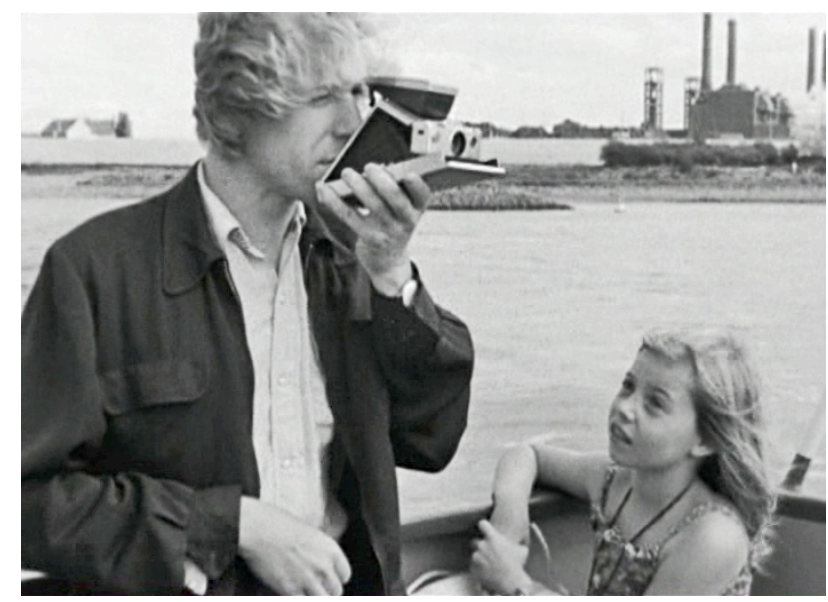

Figura 41 - Philip e Alice tentam dialogar e se unir pela imagem

Essa relação entre identidade, fronteiras e limitações permeia toda essa sua trilogia on the road inicial. Em Alice Nas Cidades (1974), o personagem Philip Winter se encontra perdido entre o texto que não evolui e o mal-estar das imagens que não conseguem dizer, com profundidade, tudo aquilo que ele conseguia ver. O seu encontro com a menina Alice representa a tentativa de um resgate identitário. Sozinhos, eles, que eram estranhos, passarão a se entender, a se descobrir e a unir as identidades desgarradas - na foto que ela faz dele, por exemplo, essa fusão é bem clara pelo reflexo do rosto dela na foto dele -, ele um enjeitado pelo mundo e ela uma enjeitada pela mãe mundo. Sem mundo e sem mãe, ambos partem dos EUA para Amsterdã e daí até outras cidades procurando um ponto de contato de Alice para com o mundo, um lugar onde ela possa ficar, onde possam se separar, visto que ao longo de todo um percurso, de toda uma jornada, eles acabam por se fundir numa mesma matéria. No filme, toda a questão da identidade de ser um estrangeiro e, ao mesmo tempo tentar se (re)conhecer em terras desconhecidas - eles tentam se reconhecer em terras desconhecidas ou o fato de serem estrangeiros acentua mais ainda a falta de identidade?, perpassa por questões que até hoje se mantém atuais. Algumas perguntas nos são feitas: Será que a fotografia consegue, de fato, reter um momento e uma verdade? O que será de nós nesse mundo de excesso de imagens mudas? Será que a televisão, com a sua programação muitas vezes grotesca e banal, será capaz de atingir a identidade do mundo, falar das experiências que 
contam? E as novas tecnologias, com as inúmeras possibilidades intermidiáticas, vão sobrepujar o cinema? Qual é o nosso verdadeiro valor neste mundo tão hostil de valores deturpados? Por ora, já temos essas respostas. E, sem o menor niilismo, elas não são lá muito animadoras. Além dessa transição e deterioração das linguagem, a contribuição filmográfica de Wenders nos remete a pensar sobre o desconforto nostálgico e, ao mesmo tempo, paralisante diante de uma realidade que restringe toda imaginação pessoal; a incapacidade de as pessoas alcançarem um bom entendimento entre si e, como desoladora compensação, a comunicação arbitrária (nos dois sentidos) e unilateral da mídia; as relações deterioradas entre homem e mulher e o expatriamento, além de uma relação profunda entre sonho, escrita e viagem que culmina na linguagem do cinema. Para entender, um pouco mais, essas relações, vamos nos recorrer novamente aos filmes.

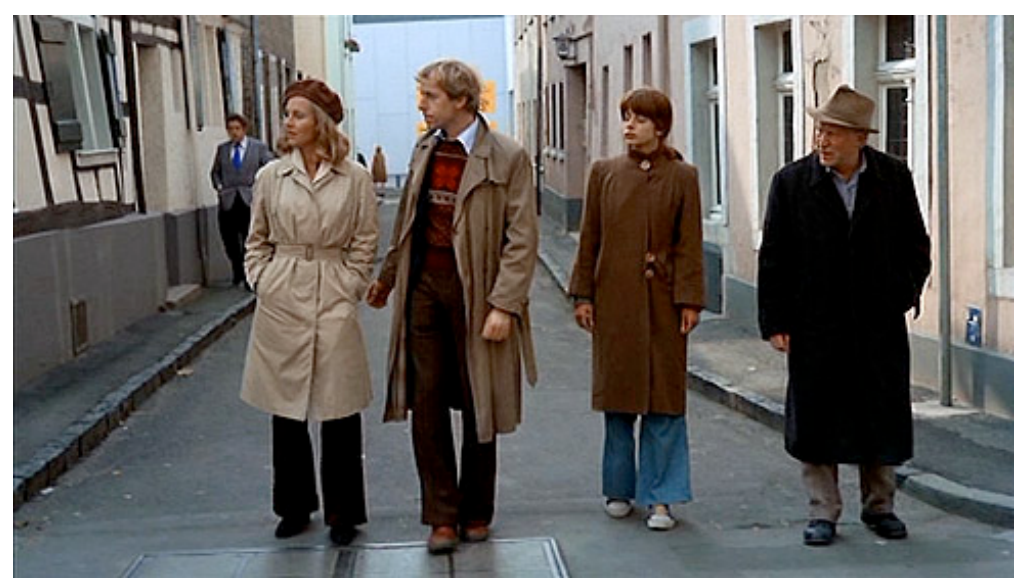

Figura 42 - Movimento em Falso: personagens em busca de algo que lhes dê sentido

Já no segundo filme desta trilogia - Movimento em Falso (Falsche Bewegung, 1975, a questão central também é a formação e aprendizagem das identidades, coletivas e individuais, através do deslocamento sobre um espaço culturalmente reconhecido que perdeu seu sentido de ser, histórico e político, demandando um novo. A obra, por sua vez, também questiona a transição entre as linguagens e pode ser lida como um exemplo significativo de aproximação entre o cinema (imaginário) e a literatura (imaginação) ao se inscrever na tentativa de representar os "fantasmas" que alimentam a tradição alemã do Bildungsroman, ou seja, do romance de formação e de sua necessidade como instrumento de produção de um discurso identitário para a Alemanha. 
Neste filme, a personagem Wilhelm se desloca por muitas paisagens na tentativa de fugir de uma mãe castradora e, ao mesmo tempo, de tentar encontrar o dom de uma escrita que ele parece não ter. Todas as pessoas que ele cruza, ao longo desse percurso, também sofrem com algum tipo de aprisionamento de um passado sufocante que parece aniquilar qualquer perspectiva de futuro. De uma maneira sutil, Wenders toca em algumas feridas (mal-estares) da humanidade: o nazismo, a frieza e o egoísmo nas relações, a co-dependência frente à solidão, a incomunicabilidade e as incertezas diante da morte. Tudo isso, mais uma vez, entremeado por uma câmera que mais parece acompanhar, de maneira silenciosa, todo esse deslocamento. A trilha utilizada por Wim Wenders em seus filmes, o rock, na maioria das vezes, entra como uma espécie de paisagem sonora. Esta, por sua vez, é um dos pontos mais inovadores da adaptação cinematográfica de Wenders. Certa vez, ele declarou em uma entrevista, no documentário Janela da Alma (2001): “...um filme sem música, para mim, seria inútil, eu jamais o faria. As imagens ficariam nuas, desprotegidas, doentes e, provavelmente, logo morreriam". Em seus trabalhos, ele faz justiça à sua própria declaração, utilizando o recurso musical também para reforçar essa relação entre a incomunicabilidade e a afirmação de uma identidade, além de garantir uma grande força pelo uso do recurso sonoro perfeito em suas produções. Ele ao mesmo tempo que usa uma trilha musical calcada no Rock para reforçar os descaminhos da estrada e os seus acasos, também se apropria dos silêncios e dos sons extradiegéticos (fora do enquadramento e do enredo) para reforçar o estado emocional das personagens ou ainda aquilo que está por vir.

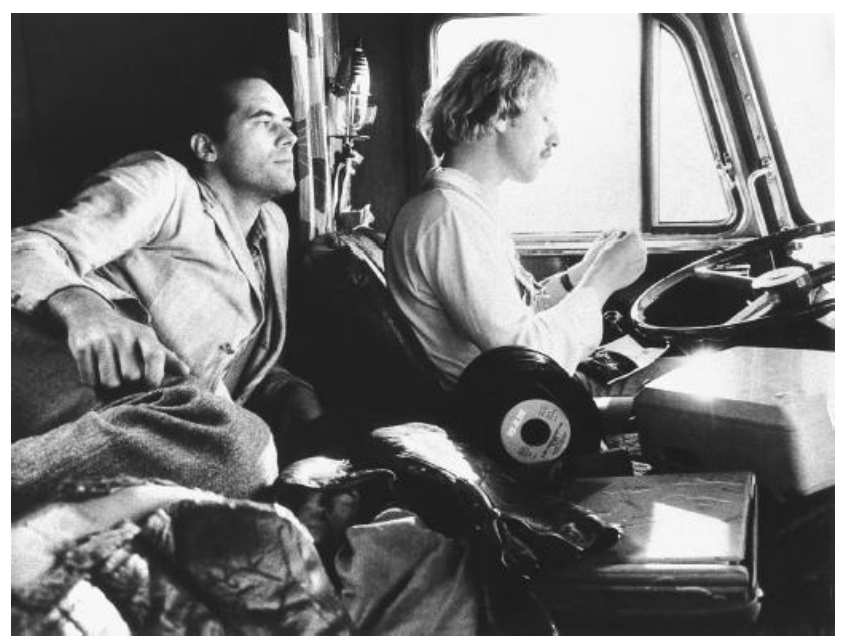

Figura 44 - Em No Decurso do Tempo: Bruno e Robert, em silêncio, se conhecem ao longo da estrada 
No último filme analisado nesta tese, No decurso do tempo (1976), percebemos o quanto Wim Wenders se esmerou, no início da sua carreira, para criar uma linguagem e deixar uma marca, inclusive, para muitos dos nossos cineastas (Walter Salles, Karim Ainouz, Lírio Ferreira, Iberê Camargo etc). De uma maneira naturalista e poética, as personagens vão se conhecendo ao longo da estrada e, por intermédio dela e das suas paisagens, vai se descortinando uma relação de amizade e de amor ao cinema. Em uma história aparentemente simples, Wenders faz uma homenagem aos primórdios do cinema e toda uma dúvida de um porvir. Por ali, ele lança alguns questionamentos: Será que ainda teremos filmes de cinema? Será que os cinemas irão resistir ao mercado, ao excesso de filmes pornográficos, templos evangélicos, estacionamentos, salas comercias e todo tipo de filme ruim? Mais uma vez, essa resposta já pode ser dada pelos enlatados americanos da sala ao lado, pelo fechamento de inúmeras salas de cinema das nossas cidades, pelos berros dos evangélicos do templo faraônico construído em São Paulo e em outras capitais. Por ali, também, se discutiu, mais uma vez, a incomunicabilidade entre as pessoas, a dificuldade de lidar com a solidão e a necessidade de se estabelecer um diálogo verdadeiro, seja na "vida real"ou na ficção, além da própria questão da identidade refletida na personagem de um projecionista de cinema e de um ex-pediatra que se deixa seduzir pelos devaneios da estrada.

Em seus filmes, Wenders faz reflexões sobre sua arte, presa entre a busca da expressão e a lógica do mercado. O cinema se olha no espelho e o que enxerga não passa de ruínas de um tempo perdido, de uma ilusão sem futuro. Muito do que veio depois já estava escrito ali. As obras de Wim Wenders buscam um equilíbrio entre a atenção às mudanças do mundo, com olhar renovador capaz de compreender o sentido destas transformações e o esforço de manter o ponto de ancoragem, idéia que mistura o cinema (e suas temáticas) com a própria carreira do diretor, ao longo das quatro últimas décadas. No ano seguinte ao No Decurso do Tempo, Wenders filmou O Amigo Americano (1977), com a ajuda de Dennis Hopper no papel de Tom Ripley, esse filme também contribuiu para o seu reconhecimento internacional.

Em seguida, Francis Ford Coppola o convida para filmar nos Estados Unidos, e depois dos grande fracasso de Hammet (1982), ele obtém sucesso de crítica com Paris Texas (1984), sua segunda produção americana, que ganha a Palma de Ouro no festival de Cannes. Já de volta à Alemanha, dirige Asas do Desejo (1987), que foi um grande 
sucesso de bilheteria e um dos principais filmes de sua carreira.

A partir deste momento, Wenders se arrisca em produções ambiciosas, alternando grandes sucessos com fracassos retumbantes. Com 4 h40 de duração, Até $o$ Fim do Mundo (1991) é ignorado pelo público, enquanto Tão Longe, Tão Perto (1993) conquista o Grande Prêmio do Festival de Cannes; já o documentário Buena Vista Social Club (1999) tem boa recepção de público, mas as ficções Estrela Solitária (2005) e Palermo Shooting (2008) recebem críticas catastróficas. Sempre fiel à experimentação, ele dirige o documentário em 3D Pina (2011) sobre a coreógrafa e dançarina Pina Baush, e decide investir na ficção em 3D com o drama Everything Wil Be Fine (2012).

Em 2014, dirigiu "O Sal da Terra", documentário sobre o fotógrafo brasileiro Sebastião Salgado, junto com o filho do fotógrafo Juliano Ribeiro Salgado. Vale ressaltar que o filme ganhou um dos maiores aplausos até no ultimo Festival de Cannes. Foi aplaudido de pé por cinco minutos ao final de sua única sessão.

Diante de sua filmografia, percebemos que observar essas obras é revisitar o passado em busca das indagações sobre o espaço e o tempo presentes. Assim como seus personagens percorrem caminhos em busca de identidade e compreensão do mundo, a experiência também se faz pela criação cinematográfica do cineasta. Muitos de seus filmes revelam uma preocupação de diagnosticar um certo estado das coisas no mundo atual e na situação do cinema, buscando diálogo com novos interlocutores, a cada filme. Todos estes filmes procuram travar um diálogo com a história do cinema, com uma grande fidelidade de todos eles a uma certa estilística própria do cinema de Wenders e reconhecível pelos espectadores por ele familiarizados. Deleuze, em A Imagem-Tempo (2007, pág. 97), observa na obra de Wim Wenders um processo de crise da imagemação, quando reflete melancolicamente sua própria morte: toma a si próprio como objeto, conta a sua própria história, pois não há mais histórias para contar. As imagens e lugares captados pelas lentes subjetivas de Wenders também podem ser pensadas como reflexo do mundo.

Wenders vem tentando compreender melhor as questões da imagem da cidade e da possibilidade de sobrevida do cinema, pelo fascínio às imagens e a recuperação da 
memória. Sua obra é ligada a uma profunda mistura de fé e desconfiança nas imagens. Afinal, restam a fotografia, a pintura e um cinema cujo fim é sentido, além de um sentimento e uma condição de expatriamento de seus personagens. A identificação de uma pátria cruel, cujos símbolos jaziam intimamente ligados à imagem do nazismo e do genocídio, certamente era difícil. Os personagens de Wenders tem uma doída consciência deste fardo histórico. Esses personagens se caracterizarão pela condição de andarilhos. Talvez à procura de uma pátria; com certeza de novas imagens.

\section{Os filmes de Wenders são descrições de um estado}

Apesar de mais de trinta anos depois do lançamento dessa trilogia, os filmes permanecem atuais, pois retornaram ao espaço do imaginário, reproduzindo sentidos à memória, aos mitos, às histórias. Porém, é preciso compreendê-los, também sob a luz de seu tempo e de suas interações, enquanto discursos fílmicos, com outros discursos anteriormente produzidos sobre o social, visto que, "entender esta interação é importante na medida em que o cinema, arte-indústria, é portador de sonhos, vontades, medos do grupo, da época que representa, e também do olhar que o grupo transmite sobre si mesmo e sobre o outro. (Rossini, 2004:12).

Alice nas cidades (1974), Movimento em Falso (1975), assim como No decurso do tempo (1976) encerram uma trilogia cujas representações do imaginário e da identidade alemã se mostram impregnadas de um violento niilismo quanto à noção da possibilidade de um projeto coletivo, de um precário comum-pertencer dentro de determinado estado político e herança histórica, da decadência do cinema enquanto linguagem atrelada a uma [est]ética do passado. E a obra posterior refletirá este malestar até a metade dos anos 1980, com Paris, Texas (1984), para depois apontar para horizontes menos melancólicos, através de seus anjos em Asas do Desejo (Der Himmel über Berlin, 1987) e muitos dos seus filmes que surgiram depois, conforme dito acima. No entanto, se pensarmos na nova filmografia que vem surgindo, não há motivo para sermos pessimistas. Pirotecnias e blockbusters à parte, o espectador tem valorizado, cada vez mais, filmes que contam histórias. Talvez seja por isso que, para Wenders, o cinema nunca esteve antes e jamais, desde então, tão próximo do seu propósito: dar uma 
imagem do homem do século XXI, uma imagem sutil, verdadeira e válida, em que ele não só se reconheça, mas com a qual sobretudo possa aprender sobre si próprio. Aliás, o próprio fazer cinematográfico de Wim Wenders é um libelo a favor do cinema, da sua capacidade de pronunciar a experiência, dizer o que é dificilmente comunicável, de nos libertar da incomunicabilidade. 


\section{Referências bibliográficas}

AGAMBEN, Giorgio. O que é contemporâneo? e outros ensaios. Tradução Vinícius Nicastro Honesko. Chapecó, SC : Argos, 2009.

AUGÉ, Marc. Não Lugares: Introdução a uma antropologia da supermodernidade. Tradução Maria Lúcia Pereira. Campinas : Papirus, 2010.

AUMONT, Jacques. Dicionário Teórico e Crítico de Cinema. São Paulo : Editora Papirus, 2004.

, Jacques. MARIE, Michel. A análise do filme. Lisboa : Edições Texto e Grafia, 2009.

ASSIS, Guilherme. "Memórias em 35mm" publicada na revista-laboratório Jenipapo, da UCB, em setembro de 2012.

AXT, Günter e SCHULER, Fernando Luir (org). Fronteiras do pensamento: ensaios sobre cultura e estética. Rio de Janeiro: Civilização Brasileira, 2010.

BAITELLO Jr, Norval, (Org.); CONTRERA, Malena Segura, (Org.); MENEZES, José Eugênio de O., (Org.); Os meios da incomunicação. São Paulo : Annablume; CISC, 2005.

O animal que parou os relógios: ensaios sobre comunicação, cultura e mídia. São Paulo : Annablume, 1999.

BARBOSA, Álvaro. O som em ficção cinematográfica. Artigo disponível em: http://www.abarbosa.org/docs/som_para_ficcao.pdf.- Acessado em 09/05/2015.

BARROS, Manoel. Ensaios Fotográficos. São Paulo : Record, 2000.

BAUER, Martin W, GASKELL, George (editores); tradução de Pedrinho A. Guareschi. Pesquisa qualitativa com texto: imagem e som : um manual prático. - Petrópolis, RJ : Vozes, 2002.

BAUMAN, Zygmunt. Tempos líquidos. Rio de Janeiro: Zahar, 2007.

, Zygmunt. Amor líquido: sobre a fragilidade dos laços humanos. Tradução Carlos Alberto Medeiros. Rio de Janeiro : Zahar, 2004.

, Zygmunt. Modernidade líquida. Tradução Plínio Dentzien. Rio de Janeiro

: Zahar, 2001.

BENJAMIN, Walter. Obras escolhidas. v. 1. São Paulo: Brasiliense, 1987.

BENTES, Ivana (Org) Ecos do cinema: de Lumière ao digital. Rio de Janeiro : Editora UFRJ, 2007. 
BETTON, Gérard. Estética do cinema. - tradução Marina Appenzeller. São Paulo : Martins Fontes, 1987.

BIRD, Robert, Andrei Tarkovsky: elements of cinema, Reaktion Books, 2008.

BOHN, David. Diálogo: comunicação e redes de convivência. - tradução Humberto Mariotti. São Paulo : Palas Athena, 2005.

BOTTON, Alain de. A arte de viajar. Tradução Clóvis Marques. Rio de Janeiro : Intrínseca, 2012.

BUCHKA, Peter. Olhos não se compram. São Paulo : Companhia das Letras, 1987.

CABRERA, Julio. O cinema pensa: uma introdução à filosofia através dos filmes. Rio de Janeiro : Rocco, 2006.

CARDOZO, Sérgio. "O olhar viajante (do Etnólogo)". Capítulo do livro O olhar. São Paulo : Cia das Letras, 1988.

CARVALHO, Walter. JARDIM, João. Janela da Alma. Documentário. 2001.

CASTRO, Gustavo de. DRAVET, Florence. Comunicação e Poesia: Itinerários do Aberto e da Transparência. Artigo apresentado nas aulas de Filosofia da Comunicação, UnB, 2011.

, Gustavo de. , Florence. Comunicação e Poesia: Itinerários do Aberto e da Transparência. Brasília : Editora Universidade de Brasília, 2014.

CHARNEY, Leo. SWARTZ, Vanessa. (Orgs) O cinema e a invenção da vida moderna. - tradução Regina Thompson. São Paulo : Cosac Naify, 2004.

CÍCERO, Antônio. Poesia e filosofia. Rio de Janeiro : Civilização Brasileira, 2012.

COHAN, Steven and HARK, Ina Rae. The Road Movie Book. London: Routledge, 1997.

COLUCCI, Maria Beatriz. "Olhares expressionistas em Wim Wenders". Artigo da Revista Lumina - Facom/UFJF - v. 2, n.2, p. $49-65$.

CORRIGAN, Timoty. A cinema without walls: movies and culture after Vietnam. New Jersey : Rutger University Press, 1991.

COTTON, Charlotte. A fotografia como arte contemporânea. - tradução Maria Silvia Mourão Netto. - São Paulo : Editora WMF Martins Fontes, 2010.

DELEUZE, Giles. A imagem-movimento. São Paulo : Brasiliense, 2007.

DIAS, Karina. Entre Visão E Invisão: Paisagem [Por uma experiência da paisagem no cotidiano] - Brasília : Editora da UnB, 2010. 
DINARDO, Wilma Patrícia Marzari “O romance de formação no Brasil. Modos de apropriação". Artigo publicado pela UNESP. Disponível em http: //www. caminhos do romance.iel.unicamp.br - Acessado em 05/03/2013.

DOBAL, Susana. "Robert Bresson: o cinema num atormentado silêncio". Artigo publicado na Sociedade Brasileira de Estudos de Cinema (Socine), Porto Alegre : Sulina, 2003.

DUBOIS, Philippe. Cinema, Vídeo, Godard. Tradução Mateus Araújo Silva. São Paulo : Cosac Naify, 2004.

EISNER, Lotte. A tela demoníaca. Tradução de Lúcia Nagib. Rio de Janeiro: Paz e Terra, 1985.

ESCOSTEGUY, Ana Carolina. "Os Estudos Culturais" Artigo disponível em: http://www.pucrs.br/famecos/pos/cartografias - Acessado em 15/06/2013.

FABRIS, Mariarosaria. (et. al.) Estudos Socine de Cinema. Ano III 2001. Porto Alegre : Sulina, 2003.

FELIPE, Marcos A. Crítica cinematográfica retirada do site: http://makingoff.org/forum/index.php?showtopic=10143. Acessado em 08/09/2014.

FERREIRA NETTO, Geraldino Alves. Wim Wenders: Psicanálise e Cinema. São Paulo: Unimarco, 2001.

FREUD, Sigmund. O Mal-Estar Na Civilização. - tradução de Paulo Cesar de Souza. São Paulo : Penguin-Companhia, 2011.

GAUDREAULT, André. JOST, François. A narrativa cinematográfica. - tradução Adalberto Müller. Brasília : Editora UnB, 2009.

GAUTHIER, Guy. O documentário - um outro cinema. Tradução de Eloisa Araújo Ribeiro. São Paulo: Papirus Editora, 2011.

GIRARDI JR., Liráucio. Teoria das mediações e Estudos Culturais: convergências e perspectivas. Artigo disponível em:

http://repositorio.uscs.edu.br/bitstream/123456789/177/2/Teoria\%20das\%20mediações $\% 20 \mathrm{e} \% 20$ Estudos\%20Culturais.pdf Acessado em 11/04/2014.

GONÇALO, Pablo. "Peter Handke, cinema e poesia." Artigo disponível em: http://revistamododeusar.blogspot.com.br/2013/06/peter-handke-cinema-e-poesia-porpablo.html Acessado em 20/06/2013.

HALL, Stuart. Identidades Culturais na Pós-Modernidade. - tradução Tomaz Tadeu da Silva, Guacira Lopes Louro. Rio de Janeiro : DP\&A, 1997. 
HOFFLER, Angélica (Org.) Cinema, literatura e história. Santo André : UniABC, 2007.

HOUELLEBECQ, Michel. Extensão do Domínio da Luta. Tradução de Juremir Machado da Silva. Porto Alegre: Editora Sulina, 2004.

JOLY, Martine. Introdução à análise da imagem. - tradução Marina Appenzeller. Campinas, SP : Papirus, 1996.

LELOUP, Jean-Yves. O corpo e seus símbolos: uma antropologia essencial. organização Lise Mary Alves de 1Ima. - Petrópolis, RJ : Vozes, 1998.

LENINE. O silêncio das estrelas. Disco Falange Canibal, Sony BMG, 2002.

LINS, Consuelo e Mesquita, Cláudia (2011). Filmar o real: sobre o documentário brasileiro contemporâneo,

LISSOVSKY, Mauricio. A máquina de esperar: origem e estética da fotografia moderna. - Rio de Janeiro : Mauad X, 2008.

LOPES, Denilson. No coração do mundo: Paisagens transculturais. Rio de Janeiro : Editora Rocco, 2012.

FRANÇA, Andréa.(Orgs.) Cinema, globalização e interculturalidade. Chapecó, SC : Argos, 2010. . A delicadeza: estética, experiência e paisagens. Brasília : Editora UnB : Finatec, 2007.

LUHMANN, Niklas. Introdução à Teoria dos Sistemas; tradução de Ana Cristina Arantes Nasser. $2^{\mathrm{a}}$ ed. - Petrópolis, RJ : Vozes, 2010. , Niklas. O amor como paixão. Rio de Janeiro : Bertrand Brasil, 1991.

LUKÁCS, Georg. A teoria do romance: um ensaio histórico-filosófico sobre as formas da grande épica. - tradução de José Marcos Mariani de Macedo. São Paulo : Duas Cidades, Editora 34, 2009.

MAAS, Wilma Patricia Marzari Dinardo. "O romance de formação no Brasil. Modos de apropriação". (Unesp) Disponível em http: //www. caminhosdoromance.iel.unicamp.br

MALAGUTI, Simone. Entrevista com Wim Wenders. Disponível em: https://epub.ub.uni-muenchen.de/20663/1/20663.pdf Acessado em 06/04/2014.

MARCHAND, Pierre. Secrets Du Cinema. Tradução Maria Alice Sampaio Dória. Paris : Éditions Gallimard Jeunesse, 1996.

MARCONDES Filho, Ciro. O escavador de silêncios: formas de construir e de desconstruir sentidos na comunicação : Nova teoria da comunicação II - São Paulo : Paulus, 2004. 
Filho, Ciro. Homem \& Mulher. Uma comunicação impossível? São

Paulo : Annablume, 2010.

MENINE JR, Mauro de Araújo. "Cinema, Imaginário e Identidade em Falsche Bewegung, de Wim Wenders". Artigo apresentado na Intercom em 2009, disponível em http://www.intercom.org.br/papers/regionais/sul2009/resumos/R16-1182-1.pdf

Acessado em 20/03/2012.

METZ, Christian. A significação no cinema. - tradução e posfácio de Jean-Claude Bernardet. São Paulo : Perspectiva, 2004.

MONTAÑO, Sonia. (et. al.) Impacto das novas mídias no estatuto da imagem. Porto Alegre : Sulina, 2012.

MONTORO, Tânia, CALDAS, Ricardo (Orgs.), De olho na imagem. - Brasília : Fundação Astrojildo Pereira, Editorial Abaré, 2006.

MOREIRA, Maria Elisa Rodrigues. "O desejo de conhecer o outro. Viagens e viajantes de Ítalo Calvino". Artigo publicado na revista Palimpsesto, Programa de Pós-Graduação em Letras da UERJ, 2011.

MORIN, Edgar. O cinema ou o homem imaginário. Lisboa : Relógio D’água editores, 1997.

MOUTINHO, Marcelo. Cegos olhos de tanto ver. Cinemais. $\mathrm{N}^{\circ}$ 17. Rio de Janeiro: Cinemais, 1999.

MÜLLER, Adalberto. Linhas imaginárias: poesia, mídia, cinema. Porto Alegre : Sulina, 2012.

NAME, Leonardo. Geografia Pop: o cinema e o outro. Rio de Janeiro : Ed. PUCRio:Ed.Apicuri, 2013.

NICHOLS, Bill. Introdução ao documentário. Tradução de Mônica Saddy Martins. São Paulo: Papirus Editora, 2008.

RAMOS, Fernão. Artigo "A MISE-EN-SCÈNE REALISTA: RENOIR, RIVETTE E MICHEL MOURLET”, disponível em http://www.iar.unicamp.br/docentes/fernaoramos/20Mise-enSceneSiteRealista.pdf Acessado em 12/08/2015.

RENNER, Rolf Günther. Edward Hopper. Transformações do Real. - tradução Casa da Línguas, Lda. Alemanha: Taschen, 1992.

ROUDINESCO, Elisabeth. Lacan a despeito de tudo e de todos. Rio de Janeiro : Zahar, 2011.

ROUILLÉ, André. A Fotografia: Entre documento e arte contemporânea. São Paulo: 
Ed. Senac, 2009.

SANTAELLA, Lucia. Comunicação e pesquisa: projetos para mestrado e doutorado. $2^{\text {a }}$ ed. - São José do Rio Preto, SP : Bluecom Comunicação, 2010.

SANTIAGO, Silviano. “O narrador pós-moderno”. In: Nas malha das letras:ensaios. Rio de Janeiro: Rocco, 2002. p.38-52.

SENNET, Richard. O Declínio do Homem Público: as tiranias da intimidade. Tradução: Lygia Araújo Watanabe. São Paulo : Cia das Letras, 1999.

SILVA, Mateus Araújo. O cinema de Wim Wenders. Cinemais. $\mathrm{N}^{\circ} 17$. Rio de Janeiro: Cinemais, 1997.

SANTOS, Jorge Alam Pereira. Incomunicabilidades: Digressões sobre o Fenômeno. Dissertação defendida na Faculdade de Filosofia da UnB, 2010.

STRECKER, Marcos. Na estrada: o cinema de Walter Salles. São Paulo : Publifolha, 2012.

TARKOVSKI, Andrei. Esculpir o tempo. - tradução Luis Carlos Borges. São Paulo : Martins Fontes, 1990.

VANOYE, Francis. GOLIOT-LÉTÉ, Anne. Ensaio sobre a análise fílmica. Campinas : Papirus, 2012.

XAVIER, Ismail (Org.) A experiência do cinema: antologia. Rio de Janeiro : Edições Graal, 1983. . O discurso cinematográfico: a opacidade e a transparência. $4^{\mathrm{a}}$ edição - São Paulo : Paz e Terra, 2008.

WECKESSER, Markus. "A Sense of Place". Entrevista com Wim Wenders publicada na FOAM International Photography Magazine, Summer 2012, p. 13 - 17.

WENDERS, Wim. Emotion Pictures. Lisboa : Edições 70, 1986.

, Wim. A lógica das imagens. Texto original publicado no jornal

Libération, caderno especial de abril de 1987.

, Wim. A lógica das imagens. Lisboa : Edições 70, 1990.

, Wim. A paisagem urbana. - tradução de Maurício Santana Dias. Artigo publicado na revista do IPHAN nº 23, 1994.

WENDERS, Wim. Places, strange and quiet. (Lugares, estranhos e quietos) - tradução de Edson Lemos. São Paulo : Imprensa Oficial do Estado de São Paulo; Mostra Internacional de Cinema de SP, 2010.

WISNICK, José Miguel. O som e o sentido. São Paulo : Companhia das Letras, 1989. 
WOOD, James. Como funciona a ficção. Tradução de Denise Bottmann. São Paulo: Cosac Naify, 2011.

\section{Filmes consultados:}

AÏNOUZ, Karin. O Céu de Suely (2006), 1h 30 minutos.

CARVALHO, Walter e JARDIM, João. Janela da Alma (2001), 73 minutos.

GOETHE-INSTITUT. Aquele que saiu à procura. Os primeiros anos de Wim Wenders. (Von einem der auszog - Wim Wenders' frühe Jahre), 2007, Documentário, 1 h 36 minutos..

FERREIRA, Lírio. Árido movie (2006), 1h 55 minutos.

FORD, John. Rastros de ódio (The searchers, 1956), $2 \mathrm{~h}$.

GOMES, Marcelo. Cinema, Aspirinas e Urubus. (2005), 1h 39 minutos.

GOMES, . Viajo Porque Preciso, Volto Porque Te Amo. (2009), $1 \mathrm{~h} 15$

minutos.

HOPPER, Dennis. Sem destino (Easy rider, 1969), 1h 30 minutos.

WENDERS, Wim. Cidade prateada (Silver city, 1969), Curta-metragem, 25 minutos.

, Wim. Alice nas cidades (Alice in den Städten,1974). Distribuído no Brasil pela Unifilmes em julho de 2012. 1h 52 minutos.

, Wim. Movimento em Falso (Falsche Bewegung, 1975). Distribuído no Brasil pela Unifilmes em julho de 2012. 1 h 39 minutos.

, Wim. No Decurso do Tempo (Im Lauf der Zeit, 1976). Europa filmes. 168 minutos.

, Wim. Um filme para Nick (Nick's Film, 1980), 1h 31 minutos.

, Wim. Quarto 666 (Chambre, 1982). Documentário, 45 minutos.

, Wim. Paris, Texas (1984), 2h 27 minutos.

, Wim. Tokyo-Ga (1985), 1h 32 minutos.

, Wim. Asas do desejo (Der Himmel über Berlin, 1987), 2h 8 minutos.

, Wim. Invisiveis (Invisibles, 2007), 1h 35 minutos.

, Wim. Pina (2011), Documentário, 1h 43 minutos.

, Wim. O sal da terra (2014), 1h 50 minutos.

SALLES, Walter. Central do Brasil (1998), 1h 45 minutos. 